\title{
Macro Sustainability across Countries: Key Sector Environmentally Extended Input-Output Analysis
}

\author{
Stanislav Shmelev ${ }^{1,2, *(1)}$ and Harrison Roger Brook $^{3}$ \\ 1 Environment Europe Foundation Stichting, Fluwelen Burgwal 58, The Hague Humanity Hub, \\ 2511CJ Hague, The Netherlands \\ 2 Environment Europe Limited, 38 Butler Close, Oxford OX2 6JG, UK \\ 3 University of Edinburgh, Edinburgh EH8 9AB, UK; s1671054@sms.ed.ac.uk \\ * Correspondence: director@environmenteurope.org; Tel.: +44-772-973-3366
}

Citation: Shmelev, S.; Brook, H.R.

Macro Sustainability across Countries: Key Sector Environmentally Extended Input-Output Analysis. Sustainability 2021, 13, 11657. https://doi.org/10.3390/su132111657

Academic Editors: Nuno Crespo and Adam Smoliński

Received: 20 May 2021

Accepted: 23 August 2021

Published: 21 October 2021

Publisher's Note: MDPI stays neutral with regard to jurisdictional claims in published maps and institutional affiliations.

Copyright: (c) 2021 by the authors. Licensee MDPI, Basel, Switzerland. This article is an open access article distributed under the terms and conditions of the Creative Commons Attribution (CC BY) license (https:// creativecommons.org/licenses/by/ $4.0 /)$.

\begin{abstract}
When formulating economic development strategies, the environment and society must be considered to preserve well-being. This paper proposes a comparative sustainability assessment method using environmentally extended input-output analysis and multi-criteria decision aid. Using symmetric input-output tables and sectoral $\mathrm{CO}_{2}$ emissions and employment data for six countries, linkage coefficients are calculated for 163 sectors in each country. Multi-criteria decision aid tool, ELECTRE III, is used to derive outranking relationships among each country's sectors using these coefficients as criteria, resulting in a hierarchy of sectors ordered by sustainability. Sectors that frequently appear at the top of the six hierarchies included education, health care, construction, and financial intermediation. China's results differ significantly because of its concentration of economic activity on the primary/secondary sectors. The results can enable identification of key intervention pathways along which sustainable development could be stimulated. Country-specific recommendations and reflections on economic and sustainability policy initiatives are discussed.
\end{abstract}

Keywords: environmentally extended input-output analysis; sustainability assessment; multi-criteria decision aid; ELECTRE III; China; USA; France; Germany; Sweden; Austria

\section{Introduction}

There is no one-size-fits-all approach to sustainable economic development that can be applied to every country, region, and city in the world. In the face of anthropogenic climate change, depletion of natural resources, dependence on fossil fuels, loss of biodiversity, and worsening socio-economic inequality; every region that intends to address these issues must tailor its sustainable development strategy in a way that considers its own unique set of economic, social, and environmental circumstances. Environmental protection and social well-being are global, not localized, issues that can only be effectively addressed in an international, coordinated manner. Global initiatives have been designed and undertaken to align different nations' sustainable development efforts towards agreed-upon goals, most notably and recently the 2015 Paris Agreement, which has been signed by 195 countries. The primary aim of the Paris Agreement is to mitigate anthropogenic climate change and ultimately hold global temperatures below 1.5 degrees Celsius above pre-industrial levels; a goal which will require careful consideration of direct and indirect GHG emissions resulting from industrial economic activity [1] (Savaresi, 2016). This paper aims to demonstrate a quantitative framework that can help individual countries most effectively identify how to sustainably manage their economies through key sector analysis, and explain the nature and causes of differences between key sectors across different countries. The six countries analyzed in this study are Austria, China, France, Germany, Sweden, and the USA. These countries were selected due to characteristics pertaining to their energy generation mix, degree of economic development, and social structure, among other factors that are further detailed in Section 2.4 . 
Understanding the complex internal structure of an economy allows one to gain a clearer picture of the nature and implications of its natural resource throughput as well as its impact on the wider social structure. Input-output analysis (I-O) is a simple yet powerful way of understanding the interdependencies of different components of an economy. EE I-O allows one to quantify the direct and indirect effects of economic activity on environmental and social indicators $\left(\mathrm{CO}_{2}\right.$ emissions and employment, respectively, in this study). The EE I-O method of key sector analysis is fundamental to gaining a clearer understanding of an economic structure and is employed to analyze the economies of the six countries. Key sectors can be calculated by different weightings, which in this case are different sectors' propensity for stimulating economy-wide final demand, $\mathrm{CO}_{2}$ emissions, and employment as measured by forward and backward linkage coefficients. Using the MCDA method ELECTRE III, the forward and backward linkages are then used as criteria to form an outranking hierarchy, at the top of which is a proxy for the most sustainable sectors in each economy. The implications of these findings for the six countries is explored in a policy discussion, and this methodology could be extended to any number of countries in order to most optimally design their approach to sustainable development.

\section{Methodological Literature Review}

In this section the theoretical underpinnings, history, and recent applications of I-O, EE I-O and MCDA are explored. The justification for selecting each of the six countries is also described. There are large bodies of existing literature for EE I-O and MCDA, and this study aims to make a valuable contribution to that body of work by performing a comparative macro sustainability analysis using the novel framework which combines both key sector identification using EE I-O and MCDA in this manner.

\subsection{Input-Output Analysis}

The flow of resources into, within, and out of a region's economy involves several fundamental components including domestic economic sectors that produce and consume output (intermediate producers/consumers); households and the government that consume output (final consumers); and foreign nations that import and export goods and services into/out of the country. I-O is concerned with the intermediate sectors in an economy and the portions of their output that are then consumed by other intermediate sectors as inputs. The core element of an I-O model is a matrix showing resource flows (usually monetary) between economic sectors over a certain period of time (usually one year) [2] (Leontief, 1986). I-O, as a field of study, was developed by Russian-American economist Wassily Leontief, for which he won the 1973 Nobel Prize in Economics. Leontief was the first to represent intersectoral transactions as a matrix. Although his work resulted in the proliferation of the study and applications of I-O, important work by several others preceded him including Francois Quesnay's Tableau économique in 1758 [3] (He, 1972), and Léon Walras's Elements of Pure Economics in 1874 [4] (Walras, 2010). Balanced, symmetric $\mathrm{I}-\mathrm{O}$ tables are derived from non-symmetric supply and use tables using methods including those outlined by [5] Eurostat (2008). The granularity of sector classification is arbitrary, and I-O tables are generated and used at a variety of sectoral resolutions (for example, the Electricity sector can be included as a whole, or it can be split into electricity generated from different sources such as coal, natural gas, nuclear, and renewables).

A variety of useful insights can be derived from I-O tables that reveal the structure of an economy and the interdependent relationships between its economic sectors. Leontief conceived the Leontief Inverse Matrix L, which is calculated as ( $-A)-1$ where I is the identity matrix and $\mathrm{A}$ is the coefficients matrix (each value $\mathrm{z}$ in the $\mathrm{I}-\mathrm{O}$ matrix as a proportion of its total output) [2] (Leontief, 1986). The Leontief Inverse has served as the basis for extensive applied economic analysis since it was first developed. Leontief's breakthrough and seminal work on the subject was his 1941 book "The Structure of the American Economy, 1919-1939: An Empirical Application of Equilibrium Analysis" [6](Leontief, 1941). In this work he validated, using 10-sector balanced input-output tables that were 
assembled using empirical data, that the general coefficient structure of the I-O tables was relatively stable over time, providing encouraging evidence that he had discovered a robust, accurately descriptive economic framework. In 1944, Leontief published "Output, Employment, Consumption, and Investment" [7] (Leontief, 1944), which applied I-O to the economic consequences of WWII. I-O was found to be practically useful to the degree that the United States Bureau of Labor Statistics adopted I-O as its preferred method of employment analysis following the war, and the government constructed a high-resolution I-O table that included 400 sectors [8] (Dorfman, 1973). Numerous other practical applications of I-O have emerged in the decades following Leontief's pioneering work and it has become a key method used in a variety of economic contexts around the world including tourism impact [9] (Fletcher, 1989), interregional trade analysis [10] (Moses, 1955), and evaluating the structure of income distribution [11] (Miyazawa, 2012), among many others.

A key concept in I-O that was developed as an extension to Leontief's work is forward and backward inter-industry linkages, which was a concept first introduced by Rasmussen [12] (1956). Forward and backward linkages are coefficients derived from the Leontief Inverse Matrix that measure the 'downstream' and 'upstream' direct and indirect influences of the activity of a particular sector on other sectors in an economy. To illustrate this in a simplified way, suppose an economy consists of three sectors; Agriculture, Manufacturing, and Transportation. Inputs into Agriculture include services provided by Transportation, which itself requires inputs from the Manufacturing sector, and so on. Therefore, expansion of the Agricultural sector results in indirect upstream expansion of both the Transportation and Manufacturing sectors. The degree to which this is the case is the backward linkage coefficient, and the same principle applies to forward linkages with downstream, consuming sectors. This methodology can be used to identify key sectors, which was an idea first proposed by [13] Hirschman (1958). Key sectors are those which have forward and backward linkage coefficients that are both greater than one, i.e., the sector is more deeply linked on average, in both directions, than all of the other sectors in the economy. Hirschman postulated that economic growth occurs primarily due to these key sectors and their above-average influence on the rest of the economy.

This was the concept underpinning unbalanced growth ([14] Akamatsu, 1961; [15] Hirschman and Lindbolm, 1962; [16] Hansen 1965). The concept of key economic sectors and linkages was further developed in a series of papers by Miyazawa ([17] Miyazawa, 1960; [18] Miyazawa, 1966; [19] Miyazawa, 1968; [20] Miyazawa, 1971) which focused on multi-regional economic systems and income multipliers. Michael Sonis and his colleagues have developed and expanded upon key economic sectors and linkages further, specifically focusing on hierarchies of key linkages/pathways and multiplier product matrices ([21] Sonis and Hewings, 1989; [22] Hewings et al., 1989; [23] Sonis and Hewings, 1992; [24] Sonis et al., 1995; [25] Israilevich et al., 1997; [26] Hewings et al., 1998; [27] Sonis et al., 2000; [28] Okuyama et al., 2004; [29] Guilhoto, Sonis and Hewings, 2005). Contemporary work in input-output analysis has included I-O database construction workflows in virtual laboratories ([30] Geschke and Hadjikakou, 2017; [31] Rahman et al., 2017; [32] Wiedmann, 2017), analyzing temporal changes in input-output networks ([33] Avelino, 2017; [34] Ye et al., 2017), and supply chain analysis ([35] Thekdi and Santos, 2016; [36] Baldwin and Lopez-Gonzalez, 2015)

\subsection{Environmentally Extended Input-Output Analysis}

Environmentally extended input-output analysis (EE I-O) builds upon I-O and is an analytical technique that aims, broadly, to calculate the hidden, indirect, or embodied environmental and/or social impacts associated with an upstream economic event ([37] Kitzes, 2013). EE I-O incorporates sectoral-level data on resource flows and usage (such as $\mathrm{CO}_{2}$ emissions and employment) in order to calculate direct and indirect intensity of these flows in response to supply/demand stimuli. It has been conceptualized as a tool to present the complexity of economy-environment interactions by Daly [38] (1968), Ayres \& Kneese [39] (1969) and Victor [40] (1971). 
EE I-O can be used to determine key paths, sectors, and linkages in an economy for environmental, economic, or social indicators ([41] Lenzen, 2003; [42] Shmelev, 2012; [43] Shmelev, 2019).

Leontief was the first to extend input-output models to account for environmental impact and other resource use/emissions types in his 1970 paper "Environmental Repercussions and the Economic Structure: An Input-Output Approach" ([44] Leontief, 1970). In this paper he calculated technical input-output coefficients in order to analyze how growth in hypothetical economic sectors affected levels of corresponding pollution. Leontief and Ford created the first empirical EE I-O analysis of pollution using a 70-sector input-output table of the United States ([45] Leontief and Ford, 1971). Shortly afterwards, Leontief compared the nature of EE I-O characteristics in developed vs. developing countries ([46] Leontief, 1974). Further environmental extensions included those focused on energy and carbon emissions: [47] Carter (1974), [48] Carter (1976), [49] Herendeen \& Tanaka (1976), [50] Proops (1977), [51] Park (1982), [52] Proops (1984), [53] Gay \& Proops (1993), [54] Polenske \& Lin (1993); [55] Minx et al. (2009), [56] Peters et al. (2011); water pollution: [57] Anderson \& Manning (1983), [58] Lenzen and Foran B. (2001), [59] Dietzenbacher \& Velázquez (2007), [60] Lenzen (2009); waste and resources: [61] Leontief (1977), [62] Duchin (1990), [63] Duchin (1994), [64] Ferrer and Ayres (2000), [65] Nakamura (1999), [66] Nakamura \& Kondo (2002), [67] Hoekstra and ven den Bergh (2002), [68] Suh (2005), [69] Kondo \& Nakamura (2005), [70] Dietzenbacher (2005), [71] Nakamura \& Kondo (2006).

Subsequent key methodological and interdisciplinary contributions were made by incorporating time-series data [72] (Barker, 1981) and MCDA ([73] Kananen et al., 1990; [74] Luptáčik and Böhm, 1994). Contemporary work in the field of EE I-O has included identifying key points of consumption that drive the emissions of particularly harmful substances such as $\mathrm{PM}_{2.5}$ ([75] Nagashima et al., 2017); assessing the sustainability of global supply chains ([76] Acquaye et al., 2017), and evaluating the consequences of food waste ([77] Reutter et al., 2017).

EE I-O is closely related to, and has heavily influenced and informed, the field of industrial ecology, which is the study of material and energy flows through industrial systems ([78] Ehrenfeld and Gertler, 1997; [79] Erkman, 1997; [80] Frosch, 1992; [81] Graedel and Allenby, 2010; [82] Jelinski et al., 1992; [83] Thomas, 1997). It has also informed the development of material flow accounting (MFA), which is the study of material flows on a national or regional scale ([84] Fischer-Kowalski et al., 2011; [85] Haberl et al., 2004; [86] Hinterberger et al., 2003; [87] Moriguchi, 1999); life cycle assessment (LCA), which is used to evaluate the environmental impacts of every stage of a product's existence (manufacturing, usage, disposal, etc.) ([88] Cabeza et al., 2014; [89] Hellweg and Canals, 2014; [90] Curran, 1996; [91] Guinée, 2001), and urban metabolism, which analyzes the flow of material and energy through cities ([92] Gandy, 2004; [93] Kennedy et al., 2011; [94] Niza et al., 2009; [95] Sahely et al., 2003).

More recent environmentally extended input-output contributions include studies by [96] Lenzen et al. (2012) who found that approximately 30\% of global species threats (as represented by the IUCN red list) are due to international trade using EORA database. In their research that linked 25,000 species to more than 15,000 commodities produced in 187 countries and evaluated over 5 bln supply chains from the point of view of their biodiversity impacts, [96] Lenzen et al. (2012) found that USA, Japan, Germany, France, UK, Italy, Spain, South Korea, Canada are the top 'net importers' of biodiversity and Indonesia, Madagascar, Papua New Guinea, Malaysia, Philippines, Sri Lanka, Thailand, Russia, Cambodia, Cameroon are the top 'net exporters'. Such analysis was possible through the links between the threatened species and implicated commodities traded in international markets. The issues of the macroeconomic impacts of individual lifestyles have been addressed in [77,97-99]. 


\subsection{Multi-Criteria Decision Analysis}

Once a sector's forward and backward linkage coefficients have been calculated and weighted by final demand, $\mathrm{CO}_{2}$ emissions, and employment, MCDA can be used to bring that information together into one singular assessment of the most optimal trade-offs between those criteria. MCDA is a broad categorization of decision-making frameworks that allow alternatives to be compared to each other according to differing criteria which are often conflicting and incommensurable. MCDA is highly suitable to this application, where sectors serve as alternatives and their forward and backward linkages serve as criteria with which the alternatives are evaluated. MCDA was initially developed in the 1960s by Bernard Roy. Since then, several branches of methods have emerged over the subsequent decades ([100] Roy and Vanderpooten, 1996).

Types of MCDA include outranking methods such as ELECTRE ([101] Roy, 1978; [102] Roy, 1990), Analytical Hierarchy Process (AHP) ([103] Handfield et al., 2002; [104] Saaty, 2008; [105] Zahedi, 1986), goal programming ([106] Ignizio, 1976; [107] Lee, 1972), weighted sum models ([108] Marler and Arora, 2010; [109] Rowley et al., 2012), and NAIADE ([110] Munda, 1995; [111] Menegolo and Pereira, 1996; [112] Munda, 2005).

The applications of MCDA are numerous, and it has historically been employed extensively in a variety of fields such as health care ([113] Nutt et al., 2010; [114] Baltussen et al., 2010; [115] Diaby et al., 2013), energy ([116] Datta et al., 2011; [117] Shmelev and van den Bergh, 2016; [118] Terrados et al., 2009; [119] Wang et al., 2009), and environmental sustainability ([120] Omann, 2004; [121] De Luca et al., 2017; [122] Fernandes et al., 2017, [123] Shmelev, 2017). MCDA has been used in conjunction with EE I-O in some cases, most notably by [82] Kananen et al. (1990), who evaluated emergency management techniques in response to the propagation of economic and political shocks through the input-output network of the Finnish economy; [74] Luptáčik and Böhm (1994), who employed a multi-objective model which aimed to minimize factor costs to produce Gross National Product (GNP) and also minimize net pollution; [42] Shmelev (2012), who used environmentally-weighted forward and backward linkage coefficients in combination with NAIADE to determine which sectors in the UK economy were the most sustainable; [124] Shmelev and Rodríguez-Labajos (2009), who assessed intertemporal macro sustainability in Austria over a 25-year period; and [125] Shmelev (2011), who used MCDA to assess macro sustainability progress over time in Russia according the UN Sustainability Development Framework of Indicators.

For this study, ELECTRE III was selected. ELECTRE III is an outranking method that was developed by Bernard Roy [101] (Roy, 1978), which incorporates realistic decisionmaking parameters for different criteria scores, namely an indifference threshold (below which one is indifferent to two alternatives by a given criterion), preference threshold (above which one displays a clear preference for one alternative over another by a given criterion), and a veto threshold (above which, for a certain criterion, an alternative outranks another by all criteria) [126] (Figueira et al., 2005). ELECTRE III was selected for this study because it is an outranking method which clearly displays the preference structure of alternatives, and because its incorporation of the aforementioned thresholds lends to a more realistic modelling of a decision-making process beyond simpler methods such as the weighted sum. It is a robust method that uses a strong sustainability concept (due to its non-compensatory nature), as opposed to the weak sustainability concept used by more rudimentary MCDA methods such as AHP ([127] Cinelli et al., 2014). The concepts of weak/strong sustainability and how they relate to MCDA are explored further in [128] Boggia and Cortina (2010); [129] Myllyviita et al. (2013); and [124] Shmelev and RodríguezLabajos (2009).

\subsection{Country Selection}

Austria, China, France, Germany, Sweden, and the USA were selected for this study because of particular economic, environmental, and social traits of interest that they possess. A comparison of the six countries by two measures each of economic, environmental, and 
social development indicators (as defined by the UK Office for National Statistics) ([130] Office for National Statistics, 2015) is shown below in Figure 1. These traits affect the structure of their economies in unique ways, and observing how these traits are revealed through descriptive EE I-O analysis could result in useful insights that policymakers can use to adapt sustainable development strategies to each of the countries. The justification for each country's inclusion in the study is set out below.

Austria was included because of the wide array of accurate data available ([124] Shmelev and Rodrigues-Labajos, 2009); the strong influence of the economy of neighboring Germany; and the importance of its primary sector compared to other similar, highlydeveloped countries.

China was selected due mainly to its relative concentration of economic activity in the primary and secondary sectors compared to the other countries analyzed. China has grown rapidly over the last (GDP growth was 3003.5\% between 1990 to 2016, compared to the global average of 234.6\%) ([131] World Bank, 2017); it is a highly $\mathrm{CO}_{2}$ emissionsintensive economy; and it acts as a point of contrast to the other five countries which are comparatively similar to each other.

France was selected primarily to explore the effect of the country's high degree of reliance on emissions-free nuclear energy, which made up $76.9 \%$ of the country's electricity generation in 2007 ([132] World Nuclear Association, 2017), the year of the EXIOPOL I-O data used in this study.

Germany is a highly $\mathrm{CO}_{2}$ emissions-intensive economy with a strong focus on its manufacturing sectors relative to other highly developed western nations; particularly its automotive manufacturing sector. Oil and coal supply $58.4 \%$ of the country's energy demand, compared to the EU average of 51.9\% ([133] BP, 2016). Germany has ambitious plans to decarbonize its economy, as outlined in its government's 'Climate Action Plan 2050' ([134] Government of Germany, 2016).

Sweden, in contrast to Germany, relies on hydroelectric power plants to supply $27.0 \%$ of its energy demand, compared to the global average of $6.9 \%$ ([133] BP, 2016). It generated $46.1 \%$ of its electricity from nuclear energy in 2007, in comparison to the aforementioned French figure ([132] World Nuclear Association, 2017). It is one of the least $\mathrm{CO}_{2}$ emissionsintensive economies in the developed world, with $\mathrm{CO}_{2}$ emissions per capita at 4.6 metric tons compared to the OECD average of 9.7 metric tons ([131] World Bank, 2017). The importance of the government, health care, and other public services to the economy of Sweden is also interesting to explore and contrast to the other countries. 

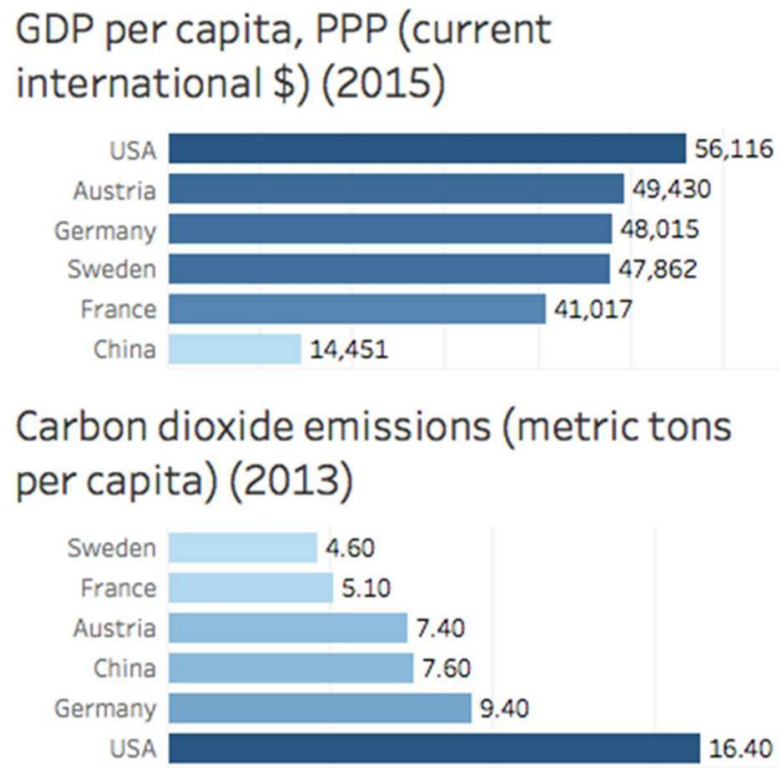

\section{Gini Coefficient}

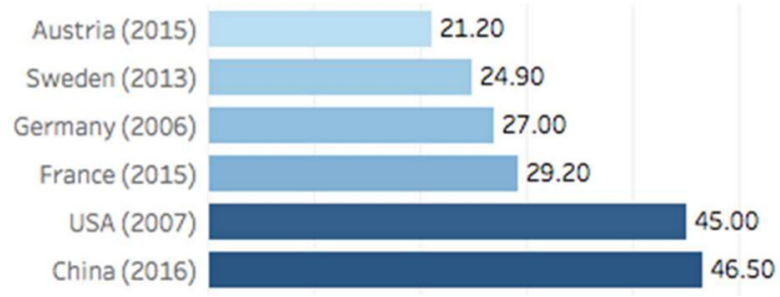

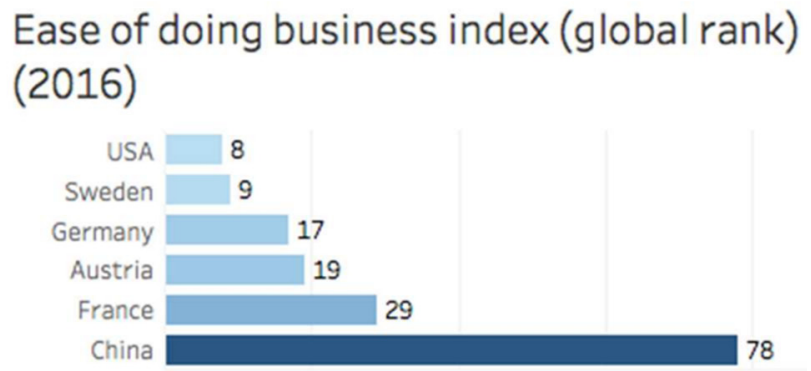

Proportion of electricity demand supplied by low-carbon sources (2016)
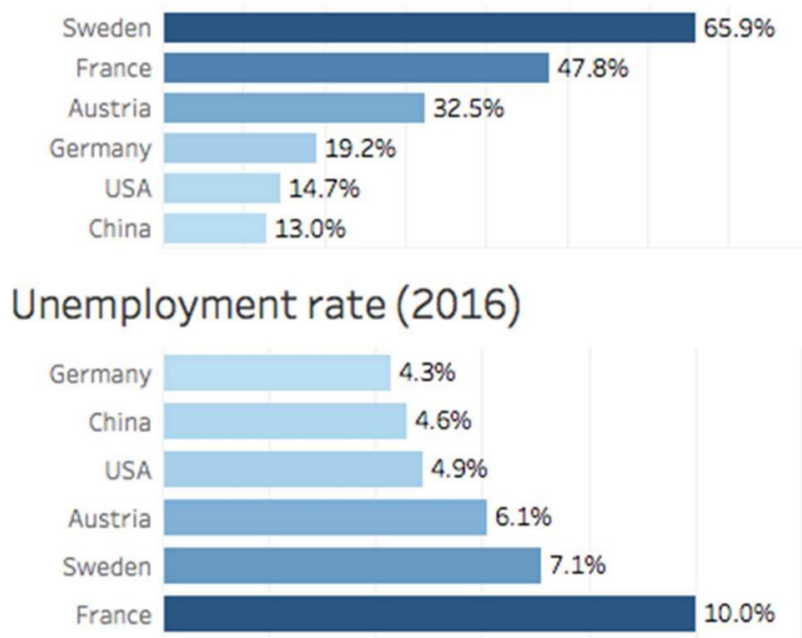

Figure 1. Comparison of the six countries by select economic, environmental, and social indicators (World Bank, 2016; BP, 2016; CIA, 2016).

The USA is included because of its size and global significance. The country made up 24.6\% of global GDP in 2016 ([131] World Bank, 2017). The USA differs in nature to the other five countries in several key ways, namely that it has much higher GDP per capita and $\mathrm{CO}_{2}$ emissions per capita (Figure 1) and it has a much larger focus on public administration and defense. Its Gini coefficient is also high relative to the other highlydeveloped nations, implying that its vast wealth is particularly skewed towards the top of its socio-economic hierarchy.

Exploring differences in key sectors between these six countries will help to shed new light on the nature of their differences, provide insight into how sustainable development strategy should be adapted to meet the unique conditions of each nation, and also strengthen the robustness of environmentally extended input-output analysis as a tool for gaining accurate, data-driven insights into complex economies.

\section{Methodology and Data Collection}

\subsection{Selecting a Data Source}

To effectively compare and contrast the six countries, a set of standardized I-O tables with corresponding sectoral final demand, $\mathrm{CO}_{2}$ emissions, and employment vectors were required. Many national governments compile and publicly release their own supply, use, and input-output tables along with labour statistics, but rarely do two countries' sector classifications align without some degree of modification or disaggregation. Fortunately, there are a number of sources of aggregated and standardized national input-output tables with corresponding environmental and resource accounts for multiple countries, five of which are compared in Table 1. 
Table 1. Comparison of aggregated input-output data sources.

\begin{tabular}{|c|c|c|c|c|c|}
\hline & OECD & EORA & GTAP & WIOD & EXIOBASE \\
\hline Reference & [135-137] OECD, 2015 & [138] Lenzen et al., 2013 & [139] Aguiar et al., 2016 & [140] Timmer et al., 2012 & [141] Tukker et al., 2013 \\
\hline Years of data available & 1995-2011 & 1990-2013 & 2004, 2007 and 2011 & $\begin{array}{l}\text { 1995-2011 (I-O Tables) } \\
\text { 1995-2009 } \\
\text { (Environmental/social } \\
\text { accounts) }\end{array}$ & 2000,2007 \\
\hline Number of regions & 61 & 186 & 147 & 40 & 43 \\
\hline Number of sectors & 34 & $\begin{array}{l}26->1000 \\
\text { Energy use, GHG and other }\end{array}$ & 57 & 37 & $\begin{array}{l}163 \\
15 \text { land use types; }\end{array}$ \\
\hline
\end{tabular}


EXIOPOL was selected as the data source for this study because:

1. It contains standardized, symmetric input-output tables for Austria, China, France, Germany, Sweden, and the USA;

2. It contains complete data for final demand as well as sector-disaggregated $\mathrm{CO}_{2}$ emissions and employment accounts;

3. It has a very high sectoral resolution (163 sectors) including separate categories for different types of electricity generation and waste management.

A disadvantage to using EXIOPOL is that the most recent data available is from 2007, whereas other sources have more up-to-date data. This fact is outweighed by the benefits listed above and does not affect the ability to illustrate this study's methodology. EXIOPOL's wide array of environmental and resource accounts are not based entirely on empirical data because of information availability limitations. The process for calculating and disaggregating the environmental accounts used in EXIOPOL is described in [13] Tukker et al. (2013). For the purposes of this study the data is sufficient to illustrate the usefulness of the method and to make reasonably accurate calculations of the $\mathrm{CO}_{2}$ emissions and employment forward and backward linkage coefficients.

\subsection{Calculating Forward and Backward Linkage Coefficients}

To calculate the forward and backward linkage coefficients for each industry weighted by each resource vector, the methodology used in Manfred Lenzen's 2003 paper 'Environmentally important paths, linkages and key sectors in the Australian economy' was employed ([41] Lenzen, 2003). The forward linkage is the resource-weighted row average of the Leontief inverse $L$, which is then divided by the resource-weighted global average of $L$. The forward linkage is the resource-weighted column average of the Leontief inverse $L$, which is then divided by the resource-weighted global average of $L$.

A linkage coefficient represents how deeply linked a sector is relative to all of the linkages in the economy. For example, a sector with a forward $\mathrm{CO}_{2}$ linkage coefficient of 1.5 is $50.0 \%$ more linked than the average of all sectors in the economy. A key sector is one which has both a forward and backward linkage greater than one, implying that is has an above-average ripple effect on economy-wide final demand, $\mathrm{CO}_{2}$ emissions, or employment in response to stimulus/contraction in that sector.

\subsection{Calculating Sector Sustainability with Multi-Criteria Decision Analysis}

After the linkage coefficients were calculated for final demand, $\mathrm{CO}_{2}$ emissions, and employment, an MCDA using ELECTRE III was used to determine which sectors have the most optimal balance of forward and backward linkage coefficients for the three categories. The intended output of this calculation is a proxy for the most sustainable economic sectors in the country in question. There are established methods in the literature that guide selection of realistic values for the indifference, preference, and threshold levels, which is inherently a highly subjective process. One such guideline is [142] Rogers and Bruen (1998a), which suggests that (a) the veto threshold $v$ should be set closer to the preference threshold as adverse human reaction to the criteria increases and $(b)$ that the preference threshold $p$ and the indifference threshold $i$ should be defined within relatively strict limits.

The threshold settings for this study are shown in Table 2. The thresholds were determined as a proportion of the difference between the highest and lowest linkage coefficients for each criteria. Indifference thresholds were set at $1.0 \%$ of the difference, preference thresholds were set at 1.1\% (reflecting the first of Rogers and Bruen's [142] principles) and veto thresholds were set at $80.0 \%$ of the difference for final demand and employment, and $70.0 \%$ of the difference for $\mathrm{CO}_{2}$ emissions (conforming to Rogers and Bruen's [142] second principle). Setting the indifference and preference thresholds so close together follows the concept of strong sustainability because there is a very small degree of compensation among criteria. 
Table 2. Criteria thresholds and goal settings for the China ELECTRE III MCDA calculation.

\begin{tabular}{|c|c|c|c|c|c|c|c|}
\hline Criteria & $\begin{array}{l}\text { Max Linkage } \\
\text { Coefficient }\end{array}$ & $\begin{array}{l}\text { Min Linkage } \\
\text { Coefficient }\end{array}$ & $\begin{array}{l}\text { Difference } \\
\text { (Max-Min) }\end{array}$ & $\begin{array}{l}\text { Indifference } \\
\text { Threshold (i) }\end{array}$ & $\begin{array}{c}\text { Preference } \\
\text { Threshold (p) }\end{array}$ & $\begin{array}{l}\text { Veto Threshold } \\
\text { (v) }\end{array}$ & Goal \\
\hline $\begin{array}{l}\text { Final demand, } \\
\text { forward linkage }\end{array}$ & 18.15 & 0 & 18.15 & 0.18 & 0.2 & 14.52 & Maximise \\
\hline $\begin{array}{l}\text { Final demand, } \\
\text { backward linkage }\end{array}$ & 14.09 & 0 & 14.09 & 0.14 & 0.16 & 11.27 & Maximise \\
\hline $\begin{array}{l}\mathrm{CO}_{2} \text { emissions, } \\
\text { forward linkage }\end{array}$ & 27.36 & 0 & 27.36 & 0.27 & 0.3 & 19.15 & Minimise \\
\hline $\begin{array}{l}\mathrm{CO}_{2} \text { emissions, } \\
\text { backward linkage }\end{array}$ & 9.79 & 0 & 9.79 & 0.1 & 0.11 & 6.85 & Minimise \\
\hline $\begin{array}{l}\text { Employment, } \\
\text { forward linkage }\end{array}$ & 9.05 & 0 & 9.05 & 0.09 & 0.1 & 7.24 & Maximise \\
\hline $\begin{array}{l}\text { Employment, } \\
\text { backward linkage }\end{array}$ & 9.27 & 0 & 9.27 & 0.09 & 0.1 & 7.42 & Maximise \\
\hline
\end{tabular}

All six criteria were equally-weighted at $16.67 \%$ each. Because of the volume of data produced for the six countries, different weighting schemes were not evaluated in this study due to scope constraints. Utilizing unequal weighting schemes is a direction for future research in this context.

\section{Results}

\subsection{Forward and Backward Linkage Coefficients}

Figures 2-7 show key sectors and forward/backward linkage coefficients weighted by final demand, $\mathrm{CO}_{2}$ emissions, and employment. Key sectors (those with forward and backward linkages greater than one) are highlighted in orange. Two countries are compared for each weighting scheme, and the complete coefficient results can be found in Appendices A and B. The countries in the following comparisons were chosen because of the nature in which their results contrast for different weightings.

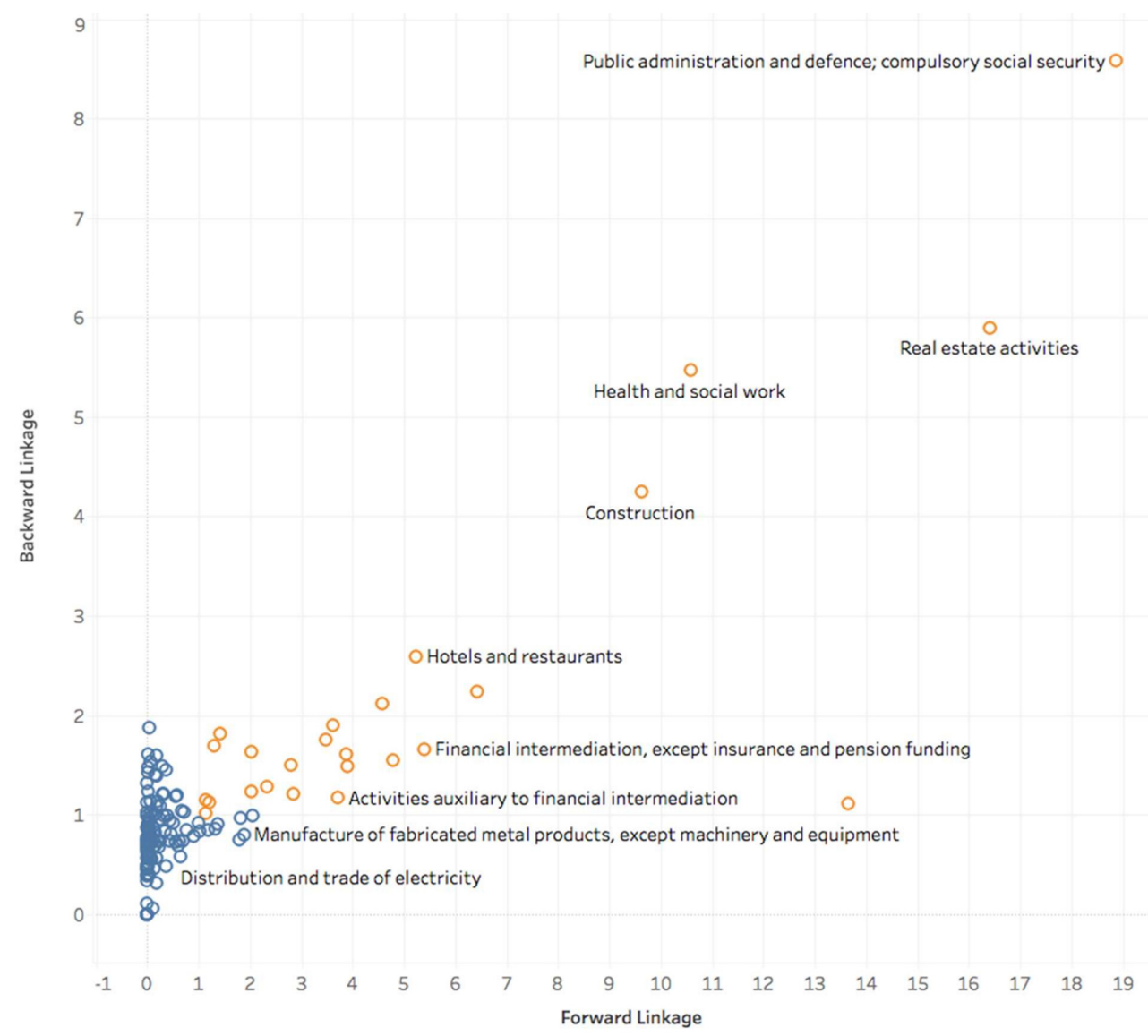

Figure 2. Final demand-weighted forward and backward linkages (USA). 
Final demand key sectors in the USA are largely centered on the services/tertiary industries, with 18 tertiary sectors out of a total of 25 key sectors. Public administration and defence is deeply linked within the USA economy because of the government's high degree of military expenditure, which totaled 3.3\% of its GDP in 2016 compared to the global average of $2.2 \%$ of GDP ([131] World Bank, 2017). Real estate activities, Health and social work, and Construction rounded out the other most deeply linked sectors. Deeply linked secondary sectors in the USA include Construction, which is typical of most countries in this study and Manufacture of motor vehicles, trailers and semi-trailers, due to the USA' status as the second-largest motor vehicle producer in the world after China.

In contrast to the USA, Germany's economy has more key sectors in the secondary/ manufacturing field (Figure 3). With 14 primary/secondary sectors out of a total of 29 key final demand sectors. Of note is the deep linkage of the Manufacture of motor vehicles, trailers and semi-trailers sector. Automotive manufacturing comprised $20.0 \%$ of total industry revenue and employed nearly 800,000 people in Germany in 2015. It is also is the most central sector overall to the German economy from a network analysis standpoint ([143] Blöchl et al., 2011). The most deeply linked final demand sector in Germany is Real estate activities, with Health and social work, Construction, Public administration and defence, and Education also strongly linked. Public administration and defence, although a key sector, is not as deeply linked as it is in the USA. Government military expenditure in Germany is $1.2 \%$ compared to $3.3 \%$ in the USA ([131] World Bank, 2017).

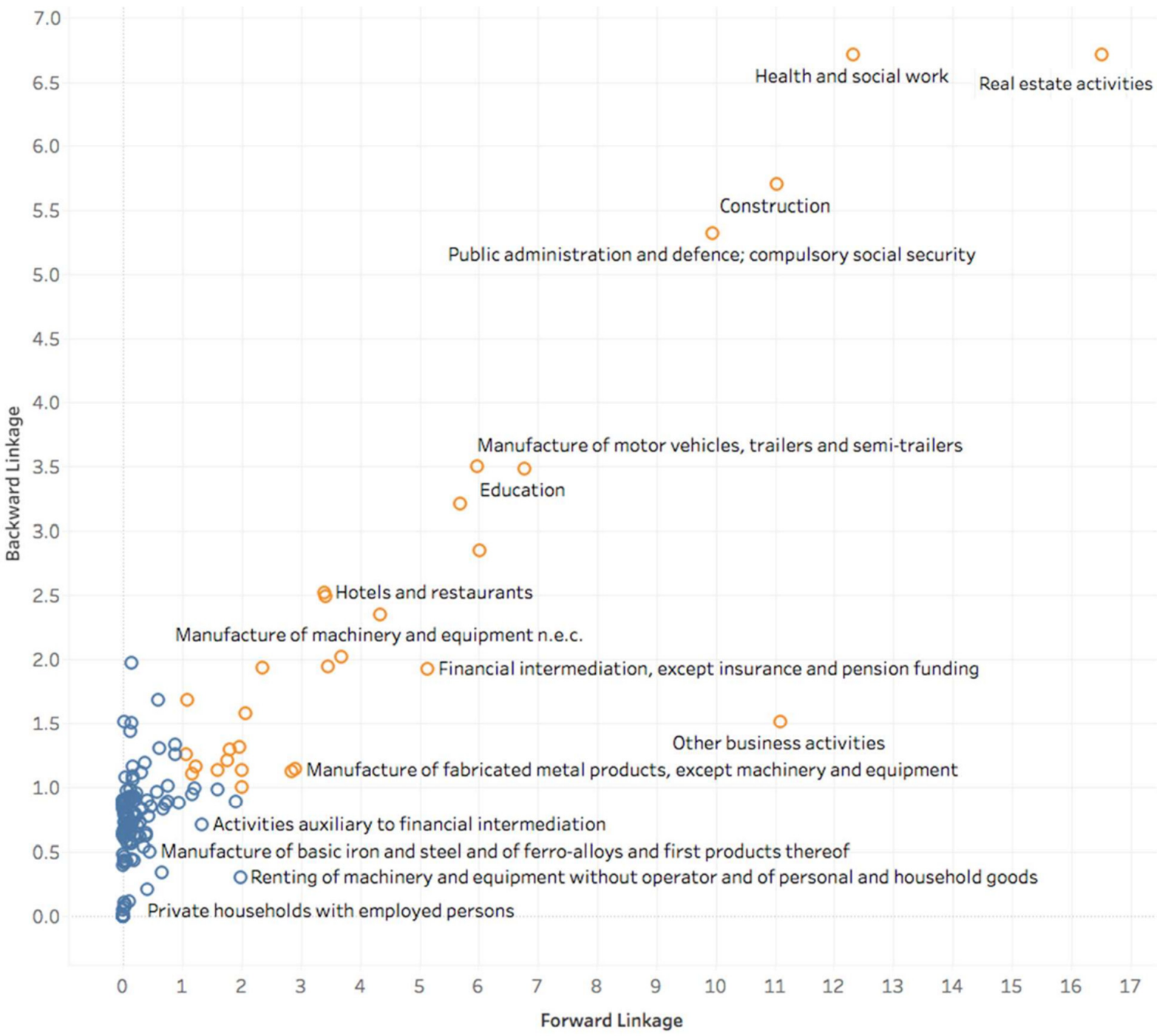

Figure 3. Final demand-weighted forward and backward linkages (Germany). 
In Austria, coal and natural gas supply $36.0 \%$ and $22.4 \%$ of total energy consumption, respectively ([133] BP, 2016). This is reflected in Figure 4 that as they are both deeply linked sectors as weighted by $\mathrm{CO}_{2}$ emissions. Manufacturing industries also have strong linkages throughout the Austrian economy, such as Manufacture of basic iron and steel and of ferroalloys and first products thereof, Manufacture of gas; distribution of gaseous fuels through mains, and Manufacture of cement, lime and plaster. Of note are sectors with very high backward linkages and forward linkages of zero, which are renewable energy generation sectors (Production of electricity by Geothermal, Production of electricity by solar photovoltaic, Production of electricity by wind, and Production of electricity not elsewhere classified). This phenomenon is unique to Austria among the six countries studied, and is important to note as the true indirect impact of renewables on $\mathrm{CO}_{2}$ emissions in Austria may be significantly higher than previously thought.

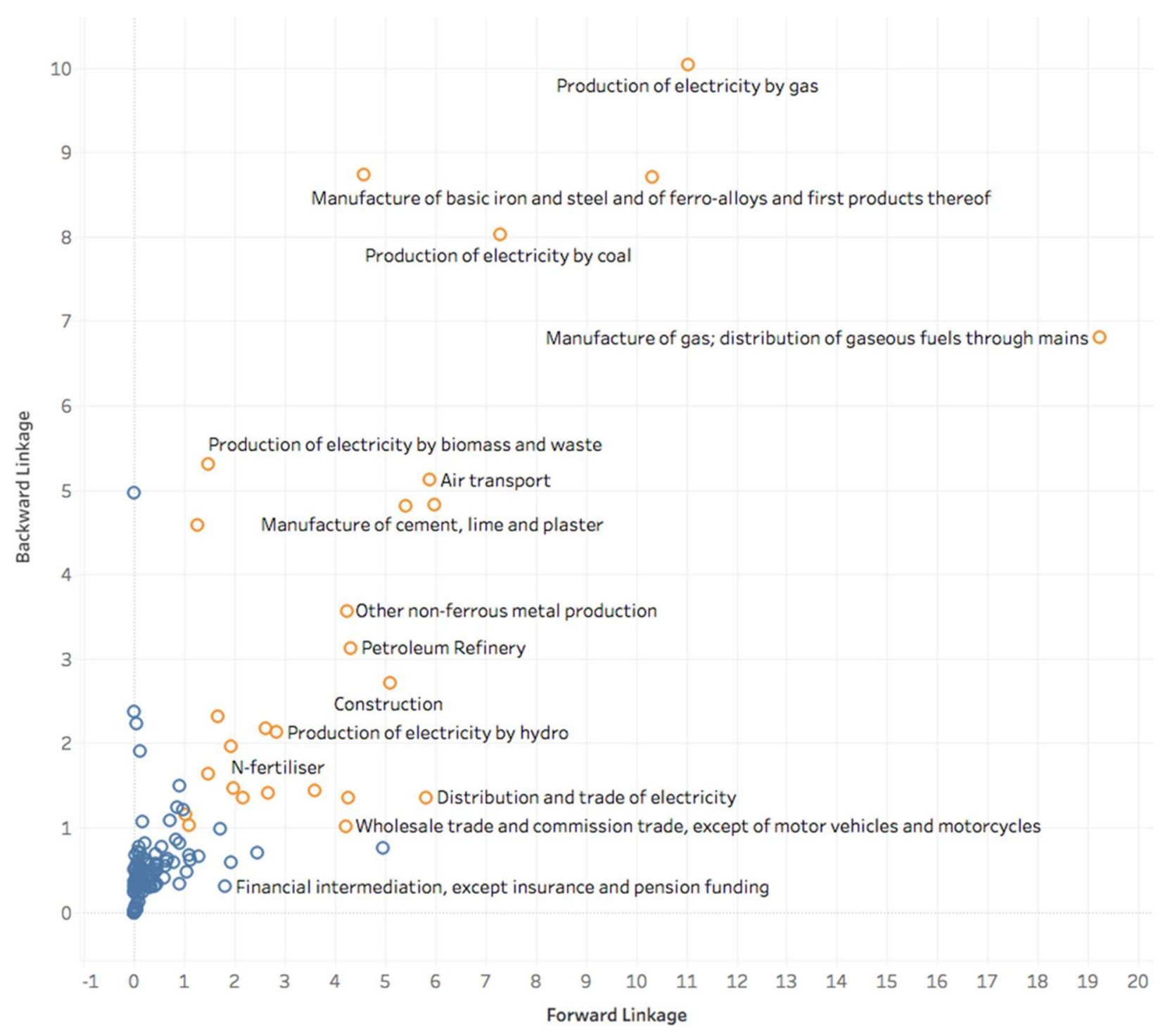

Figure 4. $\mathrm{CO}_{2}$ emissions-weighted forward and backward linkages (Austria).

By comparison, the key $\mathrm{CO}_{2}$ emissions sectors in France are shown in Figure 5. This structure is quite different than that of Austria. Because France generated $76.9 \%$ of its electricity from nuclear energy in 2007 ([132] World Nuclear Association, 2017), electricity generation sectors tend to be less deeply linked in its economy weighted by $\mathrm{CO}_{2}$ emissions. This contrast is even more striking when compared to coal-focused economies such as Germany, the USA, and China. 
The effect of Sea and coastal water transport is apparent compared to landlocked countries such as Austria. Other business activities have an unusually high forward $\mathrm{CO}_{2}$ emissions-weighted linkage, due mainly to its strong downstream linkages $\mathrm{CO}_{2}$ emissionsintense sectors such as Sea and coastal water transport; Inland water transport; and Manufacture of cement, lime and plaster.

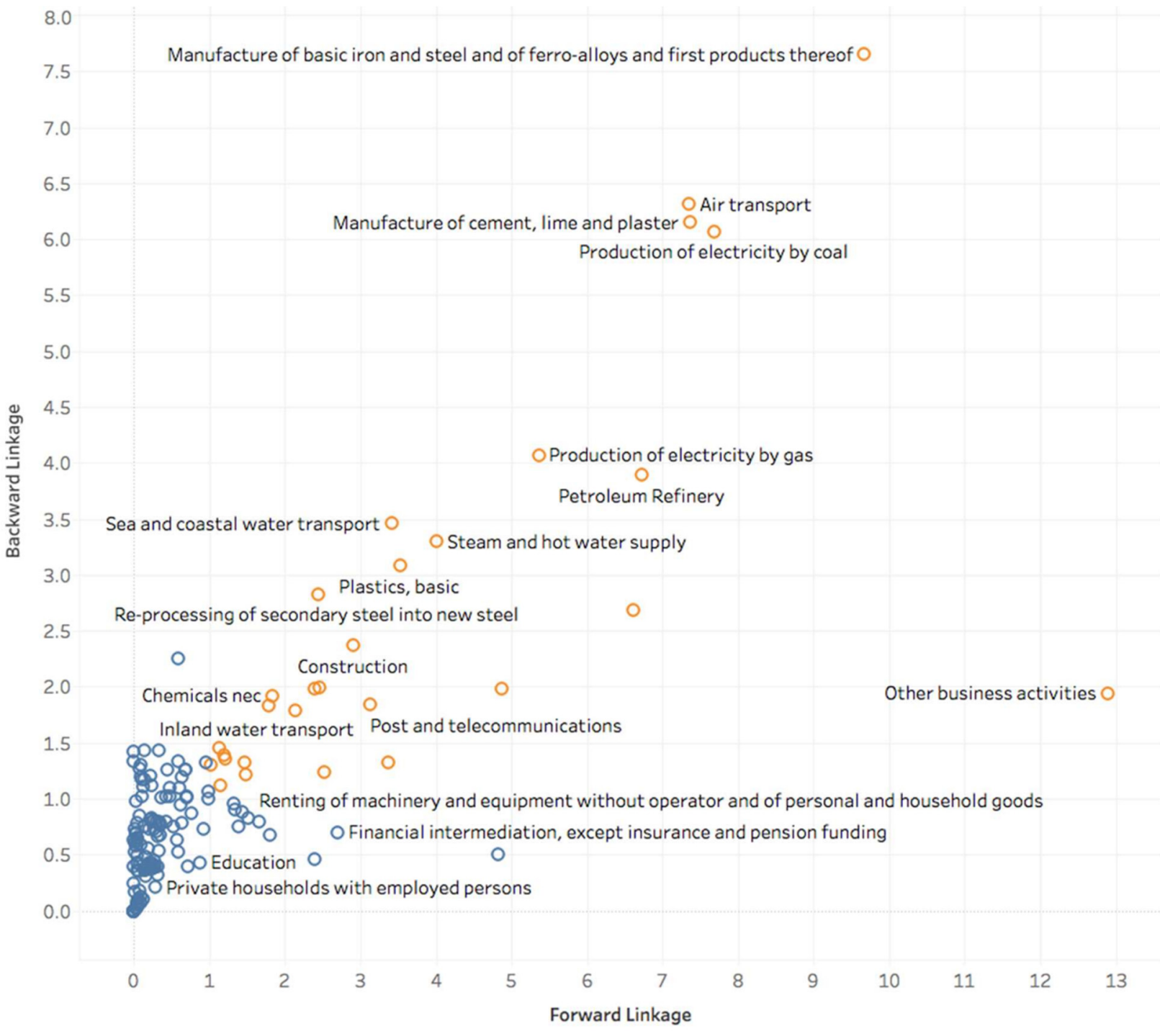

Figure 5. $\mathrm{CO}_{2}$ emissions-weighted forward and backward linkages (France).

As can be seen in Figure 6, Sweden's workforce is largely centered around the tertiary/services sectors, with Health and social work, Education, and Public administration and defence; compulsory social security employing 31.9\% of the workforce ([141] Tukker et al., 2013).

Other industries that are deeply linked include Other business activities, Construction, and Wholesale trade. Sweden is the only country where Health and social work has the highest forward and backward employment linkage coefficients. This is likely because of strong state support for healthcare and other public services in Sweden. Health expenditure as a percentage of GDP is $11.9 \%$ in Sweden, which is the second-highest out of all OECD countries apart from the USA, which spends $17.1 \%$ of GDP on healthcare ([131] World Bank, 2017), although that spending is of a different nature. 


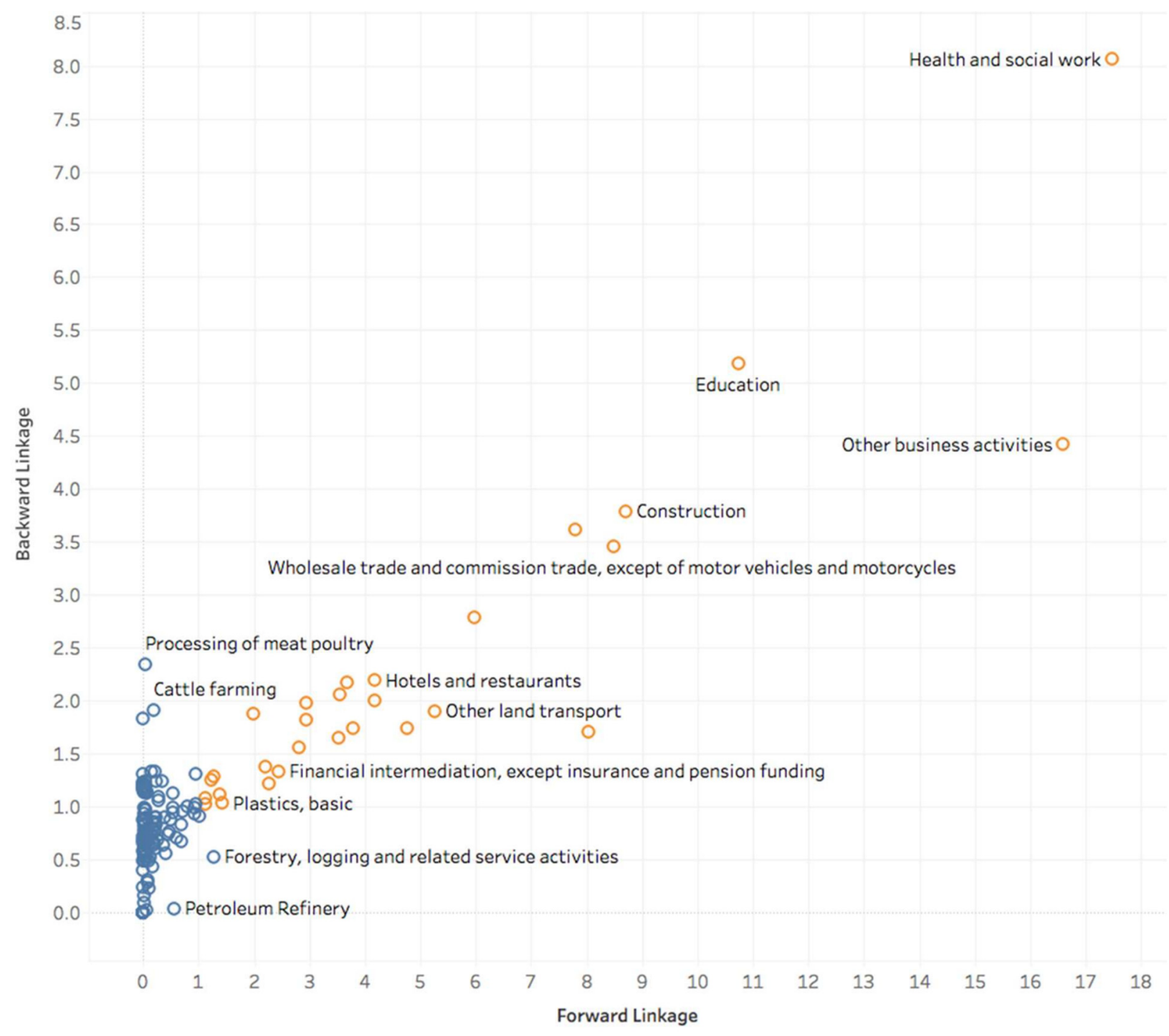

Figure 6. Employment-weighted forward and backward linkages (Sweden).

In stark contrast to Sweden, as well as to the other countries analyzed, China's labour force is largely focused on the primary and secondary production and manufacturing sectors (Figure 7). China's primary and secondary sectors employ $67.6 \%$ of its workforce, compared to $25.1 \%$ in Sweden ([141] Tukker et al., 2013). Of note are the strong backward linkages in meat production and processing in China. Production of meat pigs has a backward employment linkage of 9.27 due primarily to it drawing inputs from employment-heavy sectors such as Pigs farming; Wholesale trade; and Cultivation of vegetables, fruit, nuts. China's uniqueness among the other nations included in this study is clearly identifiable in these results and will be further elaborated upon in the following sections of this study. 


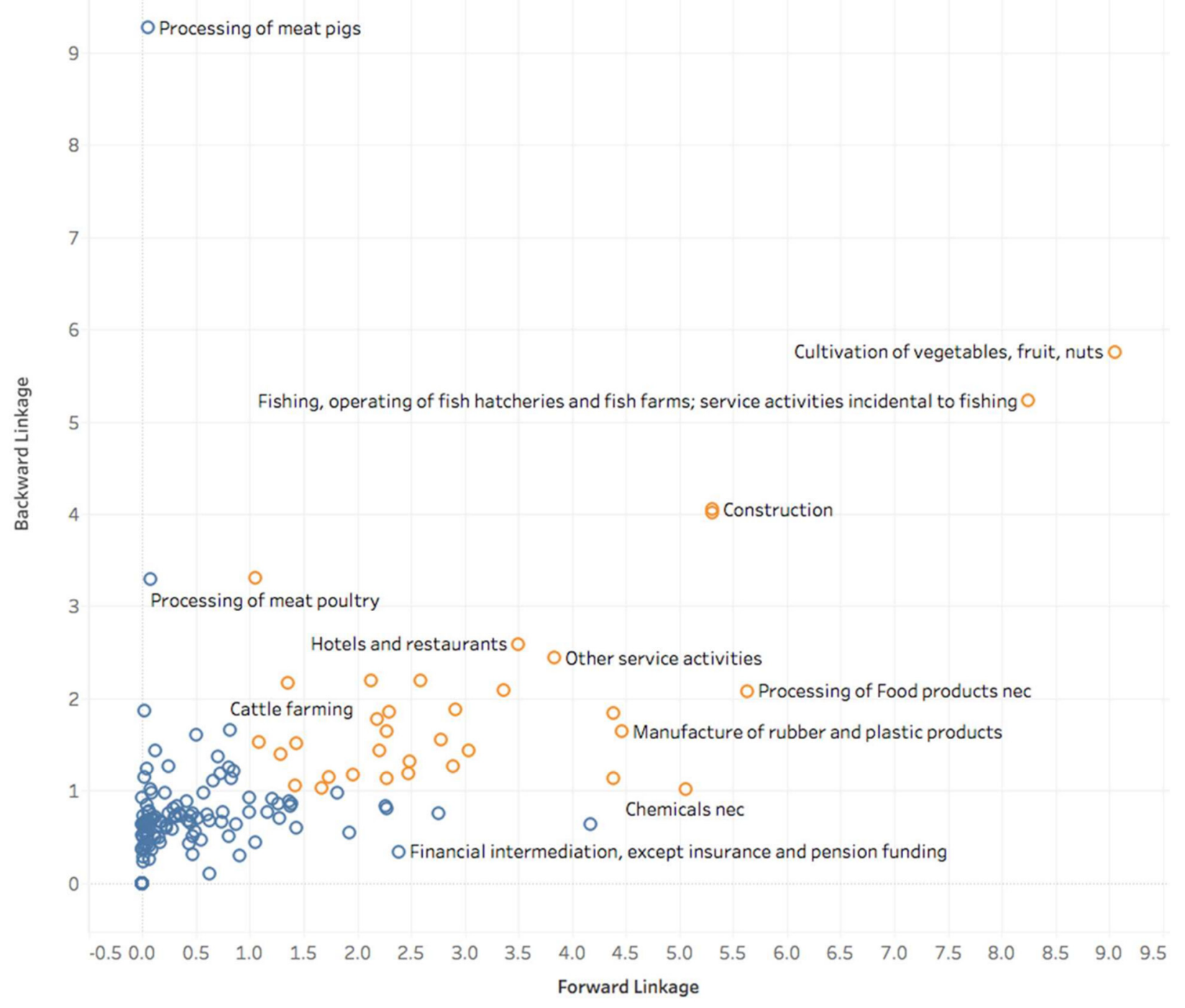

Figure 7. Employment-weighted forward and backward linkages (China).

Figures 8 and 9 visualize the dispersion of linkage coefficients in France and the USA in three dimensions, with the average $\mathrm{CO}_{2}$ linkage on the $\mathrm{x}$-axis, the average final demand linkage on the $y$-axis, and the average employment linkage encoded in the size of the circles. One can start to gain a sense of which sectors are the most sustainable by observing which sectors cluster near the top-left of the charts and have large circles indicative of high average employment linkage coefficients. Less sustainable sectors cluster near the bottomright of the chart and have small circle sizes/low employment linkages. The remaining linkage coefficient trade-off charts can be found in Appendix C.

Figures 8 and 9 show distinct differences between France and the USA. In France, Real estate activities; Construction; Health and social work; and Public administration and defence cluster towards the top-left of the chart indicating their high degree of overall sustainability. The bottom-right of the chart includes less sustainable sectors such as Manufacture of basic iron; Production of electricity by coal; and Air transport. In the USA, the scale of the x-axis extends past 28.0 to accommodate the extremely high $\mathrm{CO}_{2}$ emissions linkages from the Production of electricity by coal sector. More sustainable sectors in the USA appear to be Health and social work; Real estate activities, and Construction. Public administration and defence, although it appears to cluster at the top-left of the figure, has very high forward and backward $\mathrm{CO}_{2}$ linkage coefficients of 4.50 and 2.71, respectively. The USA military is thought to be the largest single institutional emitter of GHGs in the world, and it emitted 
over 70 million tons $\mathrm{CO}_{2}$-equivalent in 2016 (excluding foreign bases and operations) ([144] U.S. Department of Energy, 2017).

\subsection{Sector Sustainability Rankings}

Table 3 below shows the results of the ELECTRE III calculations. The five most and least sustainable sectors in each country according to the six linkage criteria are shown. They are ranked according to how many other sectors in the economy that they dominate with a cutoff proportion of 0.8 . The full rankings for all 163 sectors can be found in Appendix D.

The results of the MCDA show many similarities between the six countries, as well as some prominent differences. Education is in the top three sustainable sectors for all six countries. Health and social work is in the top three for all countries except for China. Financial intermediation appears in the top five for all countries except for China. China's top five most sustainable sectors are mostly comprised of primary and secondary industries due to the concentration of its final demand and labour force in those portions of the economy. Of note is the peculiar presence of both Mining of coal and lignite; extraction of peat and Processing of meat pigs in the top five most sustainable sectors in France. While these results seem erroneous at first, they are explained by unexpectedly high backward linkage coefficients to key final demand and employment sectors. In the case of Mining of coal and lignite; extraction of peat, the sector has strong backward linkages with (i.e., it draws heavily on for inputs) final-demand and employment heavy industries such as Other business activities; Financial intermediation, except insurance and pension funding; and Computer and related activities. Its forward and backward $\mathrm{CO}_{2}$ emissions linkages are both practically negligible, therefore it is considered much more sustainable, as calculated using this dataset, than it would seem at first glance. Processing of meat pigs has very strong backward linkages to Other business activities and Wholesale trade, which explain its high ranking in France's sustainability hierarchy. The EU's Common Agricultural Policy subsidy program could also play a role in this result. The possibility exists that these unexpected results are due to some degree of empirical inaccuracy in the data; however, the fact that their presence can be explained clearly by linkage coefficients is promising for this method's capability of eliciting and justifying unexpected and potentially valuable new insights.

The least sustainable sector results also share many similarities across the six countries. Production of electricity by gas and coal appear frequently, as would be expected due to their high $\mathrm{CO}_{2}$ emissions intensities. China's results were more similar to those of the other five countries than they were for the top five most sustainable sectors, however the presence of Collection, purification and distribution of water on the list of least sustainable sectors is notable. This is due to it drawing large amounts of input from Production of electricity by coal and Steam and hot water supply, which are both highly $\mathrm{CO}_{2}$-intensive in China. In France, both Air transport and Sea and coastal water transport are relatively unsustainable due to their very high $\mathrm{CO}_{2}$ emissions forward and backward linkages and the sectors' relatively insignificant effects on final demand and employment. In Sweden, Production of electricity by biomass and waste is highly unsustainable due to that same set of characteristics. 


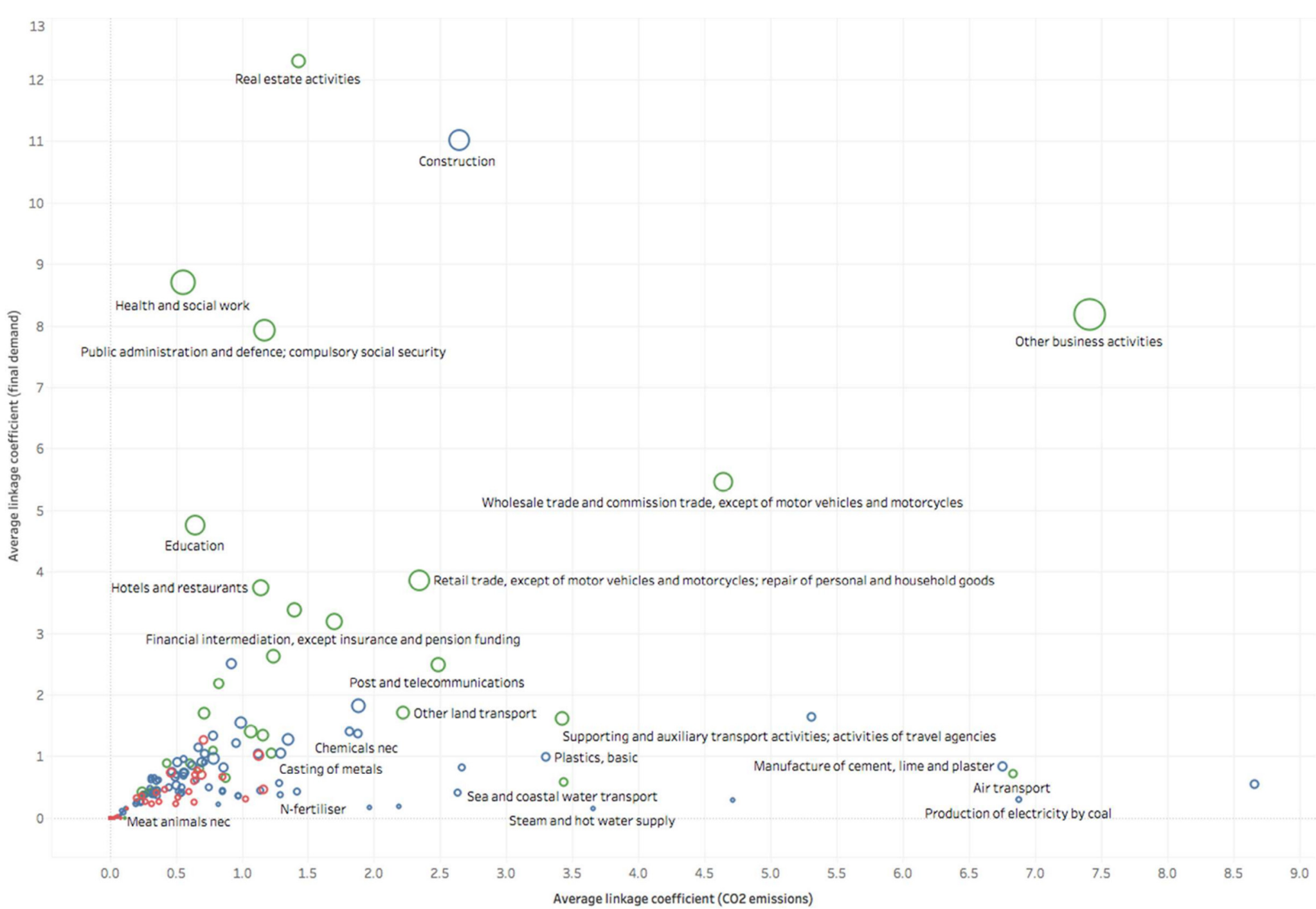

Figure 8. Trade-off of average forward and backward linkage coefficients (France). 

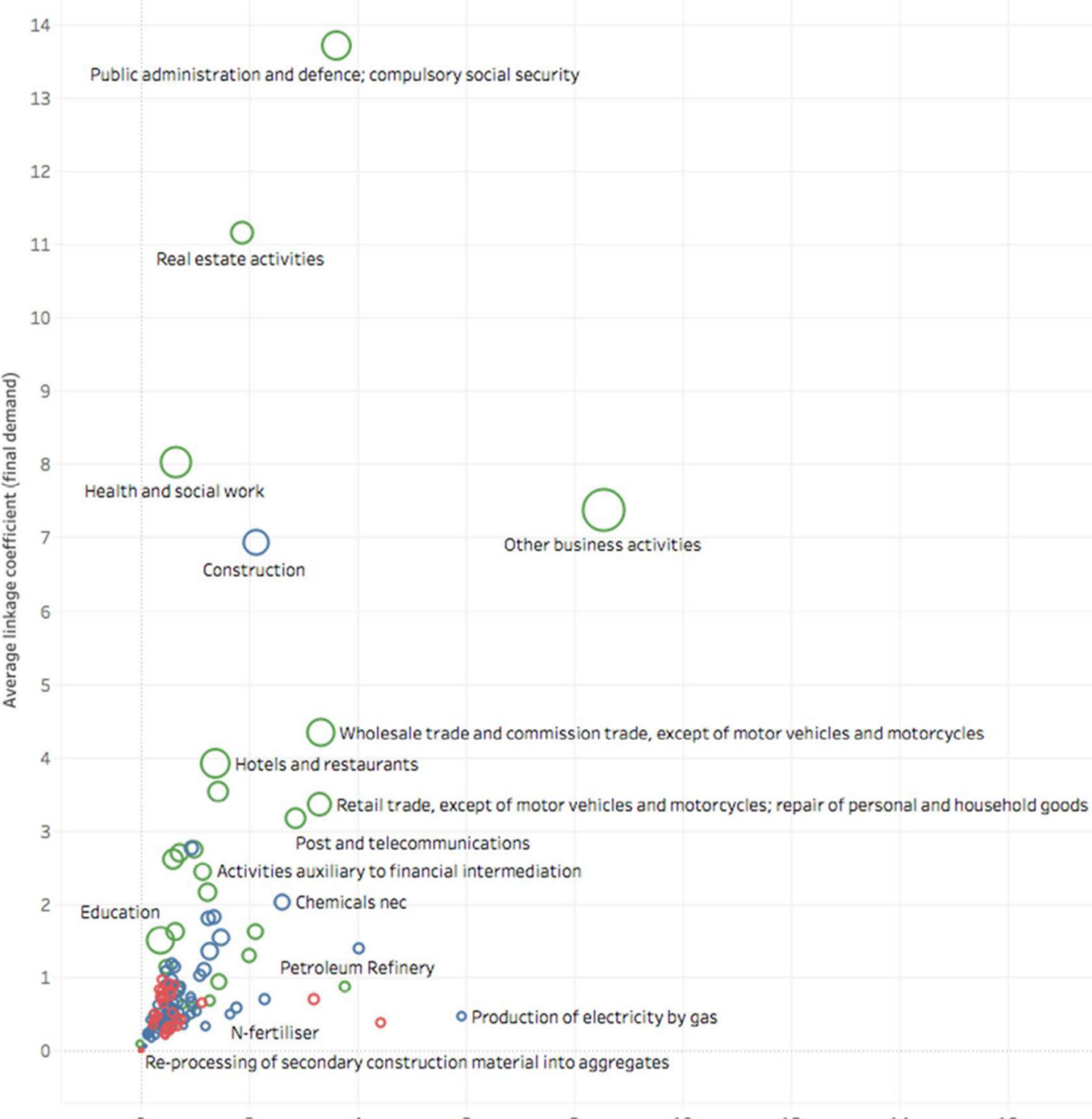

Average linkage coefficient (employment)

0.00
5.00
10.00
14.12

\section{Industry Classification}

Primary

Secondary

Tertiary

$$
\text { Average linkage coefficient (CO2 emissions) }
$$

Figure 9. Trade-off of average forward and backward linkage coefficients (USA). 
Table 3. Five most sustainable sectors by country, by number of other sectors outranked.

\begin{tabular}{|c|c|c|}
\hline Country & Rank & Sector \\
\hline \multirow{4}{*}{ Austria } & 1 & Other service activities \\
\hline & 2 & Health and social work \\
\hline & 3 & Education \\
\hline & 3 & Public administration and defence; compulsory social security \\
\hline \multirow{3}{*}{ China } & 1 & \multirow{3}{*}{$\begin{array}{c}\text { Education } \\
\text { Public administration and defence; compulsory social security } \\
\text { Fishing, operating of fish hatcheries and fish farms; service activities } \\
\text { incidental to fishing }\end{array}$} \\
\hline & 2 & \\
\hline & 3 & \\
\hline \multirow{3}{*}{ France } & 1 & Health and social work \\
\hline & 2 & Education \\
\hline & 3 & Processing of meat pigs \\
\hline \multirow{3}{*}{ Germany } & 1 & Health and social work \\
\hline & 2 & Education \\
\hline & 3 & Hotels and restaurants \\
\hline \multirow{3}{*}{ Sweden } & 1 & Health and social work \\
\hline & 2 & Education \\
\hline & 3 & Hotels and restaurants \\
\hline \multirow{3}{*}{ USA } & 1 & Education \\
\hline & 2 & Health and social work \\
\hline & 3 & $\begin{array}{l}\text { Sale, maintenance, repair of motor vehicles, motor vehicles parts, } \\
\text { motorcycles, motor cycles parts ... }\end{array}$ \\
\hline
\end{tabular}

\section{Discussion}

\subsection{Differing Economic Structures of the Six Countries}

The results of the above analysis reveal as many similarities between the six countries as they do differences. Many of the countries share key sustainable sectors, and the implications of any differences in economic structure can be drawn by comparing the five highly-developed, western countries (Austria, France, Germany, Sweden, and the USA) to China, which is still rapidly developing and has a greater economic focus on its primary and secondary industries. Sectors appearing at or near the top of the MCDA hierarchies for most of the five western countries include Health and social work; Education; Financial intermediation, except insurance and pension funding; Insurance and pension funding, except compulsory social security; Hotels and restaurants; Computer and related activities; and Other service activities.

These sectors contribute greatly to final demand and therefore economic growth while employing the largest portions of the countries' workforces. Sectors appearing most frequently at the bottom of the MCDA hierarchies in these countries are generally those associated with electricity production using fossil fuels and extractive industries, particularly mining of metals and ores. Air transport is also quite unsustainable in these countries due to that industry's enormous usage of fossil fuels which result in high amounts of $\mathrm{CO}_{2}$ emissions. By comparison, China's most sustainable sectors contain some of the tertiary industries found at the top of the MCDA in the five western countries, however agricultural and other primary/secondary sectors play more important roles in China, comparatively. The most sustainable sectors in China include Education; Public administration and defence; compulsory social security; Fishing, operating of fish hatcheries and fish farms; service activities incidental to fishing; Cultivation of vegetables, fruit, nuts; Processing of Food products nec; and Manufacture of fish products, many of which are primary and secondary sectors. The tertiary sectors only account for $37.2 \%$ of China's total final demand and 32.4\% China's of total employment. This is about half of the equivalent figure in the other five countries, on average. A breakdown of the broad final demand and employment structures of the 
six countries can be seen in Figure 10. Of note is China's heavy employment focus on its primary agricultural/extractive industries, which comprise $42.1 \%$ of total employment, although they contribute only $6.0 \%$ of final demand.

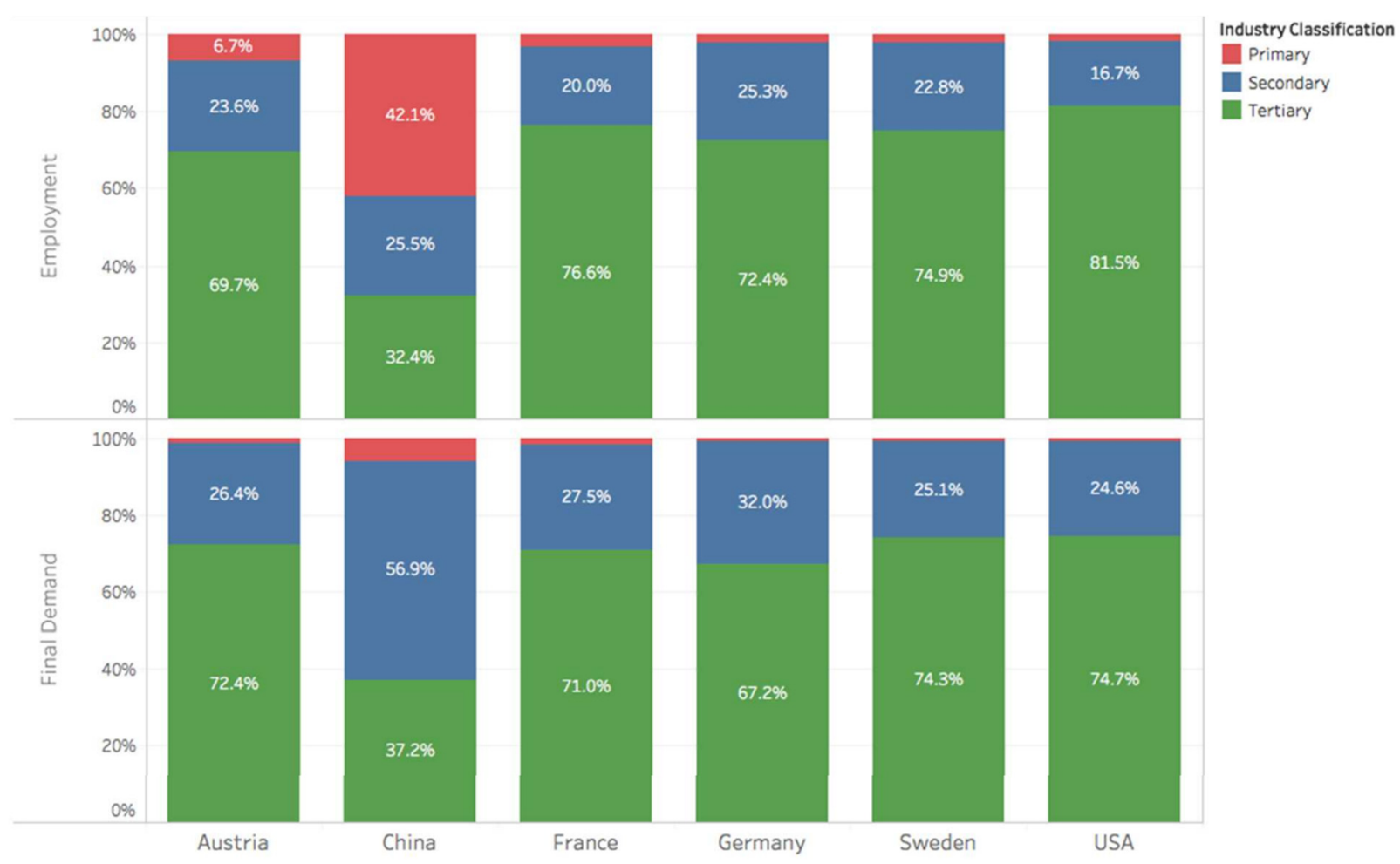

Figure 10. Industry make-up of final demand and employment across the six countries.

\subsection{Policy Implications}

The insights gained from this study could be highly useful to policymakers who are formulating green economy and investment policies. First, it can offer guidance on where to focus the greening efforts by identifying sectors that are either clearly unsustainable, or are highly economically beneficial but do not have strong linkages with employment and are particularly harmful in their indirect effects on the environment. A list of such 'pitfall' industries is shown below in Table 4, which shows the list of sectors that have a strongly positive impact on the economy in terms of final demand, but are not particularly beneficial in terms of employment and have above-average upstream and downstream $\mathrm{CO}_{2}$ emissions linkages. These are distinguished from the most unsustainable sectors, as many of those tend not to be economically-attractive sectors.

Table 4. Pitfall sectors in the six countries (those with above-average final demand linkages; above-average $\mathrm{CO}_{2}$ emissions linkages; and below-average employment linkages).

\begin{tabular}{|c|c|c|c|c|c|}
\hline Austria & China & France & Germany & Sweden & USA \\
\hline $\begin{array}{l}\text { Processing of Food } \\
\text { products nec }\end{array}$ & $\begin{array}{l}\text { Distribution and } \\
\text { trade of electricity }\end{array}$ & $\begin{array}{l}\text { Processing of Food } \\
\text { products nec }\end{array}$ & Petroleum Refinery & - & - \\
\hline $\begin{array}{l}\text { Transmission of } \\
\text { Electricity }\end{array}$ & & Chemicals nec & & & \\
\hline \multicolumn{6}{|l|}{$\begin{array}{l}\text { Distribution and } \\
\text { trade of electricity }\end{array}$} \\
\hline Air transport & & & & & \\
\hline
\end{tabular}


Actionable steps that can be taken by policymakers from the results of this study include designing or re-designing economic development and investment plans around the sectors that are the most and least sustainable. The methodology used is flexible and could evolve continually to incorporate new data and shifting objectives, which is important considering sustainable development strategy should be highly dynamic and adaptable ([145] El-Erian and Spence, 2008).

Each of the six countries has ratified the 2015 Paris Agreement. In addition to this shared objective, they also have clearly defined sustainable development strategies, which could benefit to some degree from insight gained using this study's methodology. The Austrian government has long displayed its commitment to environmental protection through successful pollution reduction initiatives, relatively high environmental spending as a proportion of GDP, and a commitment to future green growth through its 'Masterplan Green Jobs' and 'Growth in Transition' initiatives ([146] OECD, 2013). Its policy support for renewable energy is strong with $100 \%$ of electricity in its largest state, Lower Austria, now being generated from renewables ([147] France-Presse, 2015). China has historically been one of the most environmentally-impactful nations on earth due to severe air pollution resulting from industrial activity ([148] Chan and Yao, 2008; [149] Feng, 1999). However, its government has adopted more environmentally-friendly policies in recent years, with renewable energy near the forefront of that focus ([150] Xiao et al., 2017; [151] Zhao and Luo, 2017). China planned to invest $£ 292$ billion into renewable power by 2020 ([152] Reuters, 2017). France has ambitious sustainable development targets including those outlined in its 2015 'Energy Transition for Green Growth Act' and its role as a driving force in the formulation and international adoption of the Paris Agreement ([153] OECD, 2016). However, France still relies heavily on nuclear energy, although that reliance is falling. Its percentage of electricity generated from nuclear come down from $78.1 \%$ in 2006 to $72.3 \%$ in 2016 ([132] World Nuclear Association, 2017). Germany is highly ambitious in its plans to decarbonize its economy, particularly as it relates to renewable energy policy. Ultimately, it hopes to reduce its total GHG emissions by $80 \%$ to $95 \%$ by 2050 as per its 'Climate Action Plan 2050' ([134] Government of Germany, 2016). At present, Germany' economy is highly $\mathrm{CO}_{2}$-intensive and there is much potential for improvement which could be streamlined by identifying and growing key sustainable sectors. Sweden is perhaps the most environmentally successful of the six countries due to its government's highly ambitious policy support for sustainability, which has resulted in drastic GHG emissions reductions in recent decades ([146] OECD, 2013). Its proximity to the Baltic Sea and the issues surrounding overfishing in that region will continue to be a primary concern for Sweden in the future ([154] Lindegren et al., 2009). The USA currently faces major challenges to its policy support for sustainable development due actions by its current federal government that include proposed funding cuts to its Environmental Protection Agency ([155] Neslen, 2017) and efforts to increase domestic coal production and exports ([144] U.S. Energy Information Administration, 2017). It has also signaled its intention to withdraw from the Paris Agreement ([83] Thomas, 2017).

In spite of this, some individual states are pursuing their own ambitious sustainability and renewable energy policy targets. For example, California's "2030 Climate Commitment" aims to generate half of the state's electricity from renewables by 2030 ([156] State of California Energy Commission, 2015). The state of Oregon has also legislated a requirement for 50\% of its electricity to be derived from renewables by 2040 ([157] Oregon Department of Energy, 2016).

\section{Conclusions}

In this study, EE I-O and MCDA have been employed to identify the most sustainable sectors out of a total of 163 sectors in six countries (Austria, China, France, Germany, Sweden, and the USA) according to their economic, environmental, and social impact. Specifically, forward and backward linkages based on the Leontief Inverse Matrices of the I-O tables were weighted by final demand, $\mathrm{CO}_{2}$ emissions, and number of employees to 
determine those sectors that had above average upstream and downstream impacts on the economy as a whole. The linkages for each country were then used as criteria in an MCDA calculation using the ELECTRE III method. This process created a hierarchy of dominant relationships between sectors that showed which sectors were most optimal in maximizing final demand and number of employees, whilst reasonably minimizing $\mathrm{CO}_{2}$ emissions. The results for the six countries reflected the underlying fundamental differences in the structure and nature of these economies, and these differences are contrasted and assessed for their implications and significance to policymakers. Sectors that were most frequently identified as being highly sustainable in most or all of the six countries included Education, Health and social work, and Hotels and restaurants.

The least sustainable sectors included Production of electricity by gas, coal petroleum and other oil derivatives; mining of metals and other ores; Manufacture of cement, lime and plaster; and Air transport. Some sectors that were sustainable in some countries were highly unsustainable in others, and vice versa. Examples of this include Cultivation of crops not elsewhere classified, which is far more unsustainable in France than it is on average for the other countries; Financial intermediation, except insurance and pension funding, which is far more unsustainable in China than it is on average for the other countries; and Mining of aluminum ores and concentrates, which is far more sustainable in France than it is on average for the other countries. These results prove that there is no effective one-size-fits-all policy strategy for sustainable development that applies to all countries. Taking these coefficients into account can help individual nations optimize their pursuit of sustainable development so that collective international targets such as the Paris Climate Agreement can be met in the most efficient and effective way possible.

Author Contributions: Conceptualization and methodology, S.S., formal analysis, H.R.B., data curation, S.S., writing - original draft preparation, H.R.B., validation, S.S., writing-review and editing, S.S., supervision, S.S., project administration, S.S. All authors have read and agreed to the published version of the manuscript.

Funding: This research received no external funding.

Institutional Review Board Statement: Not applicable.

Informed Consent Statement: Not applicable.

Data Availability Statement: All data generated in this research remains property of Environment Europe Limited and Environment Europe Foundation.

Conflicts of Interest: The authors declare no conflict of interest.

\section{Appendix A. Complete Forward and Backward Linkage Coefficients}

Table A1. Complete forward and backward linkage coefficients for all six countries Key sectors where the forward and backward linkage are both greater than one are highlighted in green. An index of sector ID numbers and their corresponding full names can be found in Appendix D of this paper.

\begin{tabular}{|c|c|c|c|c|c|c|c|c|c|c|c|c|}
\hline \multirow[b]{3}{*}{ Sector ID } & \multicolumn{6}{|c|}{ Austria } & \multicolumn{6}{|c|}{ China } \\
\hline & \multicolumn{2}{|c|}{ Final Demand } & \multicolumn{2}{|c|}{$\mathrm{CO}_{2}$} & \multicolumn{2}{|c|}{ Employment } & \multicolumn{2}{|c|}{ Final Demand } & \multicolumn{2}{|c|}{$\mathrm{CO}_{2}$} & \multicolumn{2}{|c|}{ Employment } \\
\hline & Fwd & Bckwd & Fwd & Bckwd & Fwd & Bckwd & Fwd & Bckwd & Fwd & Bckwd & Fwd & Bckwd \\
\hline 1 & 0 & 0 & 0 & 0 & 0 & 0 & 0.57 & 0.21 & 0.58 & 0.48 & 2.49 & 1.32 \\
\hline 2 & 0.07 & 0.69 & 0.15 & 0.35 & 0.42 & 0.81 & 0.38 & 0.23 & 0.15 & 0.36 & 1.38 & 0.83 \\
\hline 3 & 0.21 & 0.66 & 0.44 & 0.54 & 0.98 & 0.92 & 0.5 & 0.31 & 0.22 & 0.44 & 1.67 & 1.03 \\
\hline 4 & 0.46 & 0.81 & 0.43 & 0.58 & 1.13 & 1.11 & 3.06 & 2.08 & 0.7 & 0.52 & 9.05 & 5.76 \\
\hline 5 & 0.04 & 0.37 & 0.07 & 0.18 & 0.09 & 0.38 & 0.32 & 0.19 & 0.15 & 0.29 & 1.39 & 0.86 \\
\hline 6 & 0.02 & 0.7 & 0.04 & 0.26 & 0.08 & 0.7 & 0.22 & 0.14 & 0.14 & 0.17 & 1.37 & 0.89 \\
\hline 7 & 0 & 0.02 & 0 & 0 & 0 & 0.02 & 0.09 & 0.25 & 0.06 & 0.43 & 0.74 & 0.66 \\
\hline 8 & 0.22 & 0.8 & 0.08 & 0.34 & 1.25 & 1.13 & 0.71 & 0.54 & 0.13 & 0.21 & 2.92 & 1.88 \\
\hline 9 & 0.11 & 2.17 & 0.15 & 1.07 & 1.21 & 2.91 & 0.23 & 1.46 & 0.19 & 0.54 & 0.82 & 1.66 \\
\hline 10 & 0.25 & 0.85 & 0.07 & 0.38 & 0.79 & 1.29 & 1.36 & 1.41 & 0.54 & 0.38 & 5.31 & 4.01 \\
\hline
\end{tabular}


Table A1. Cont.

\begin{tabular}{|c|c|c|c|c|c|c|c|c|c|c|c|c|}
\hline 11 & 0.15 & 0.71 & 0.01 & 0.34 & 0.27 & 0.85 & 0.65 & 1.78 & 0.21 & 0.52 & 1.35 & 2.17 \\
\hline 12 & 0.08 & 0.07 & 0.02 & 0.02 & 0.04 & 0.06 & 0.15 & 0.93 & 0.03 & 0.26 & 0.8 & 1.25 \\
\hline 13 & 0.08 & 0.07 & 0.01 & 0.02 & 0.04 & 0.06 & 0.24 & 1.44 & 0.04 & 0.41 & 0.5 & 1.61 \\
\hline 14 & 0.32 & 0.52 & 0.16 & 0.24 & 1.3 & 1.07 & 0.29 & 1.11 & 0.16 & 0.74 & 0.7 & 1.37 \\
\hline 15 & 0 & 0.51 & 0 & 0.23 & 0 & 0.58 & 0.01 & 0.78 & 0.01 & 0.32 & 0.06 & 0.78 \\
\hline 16 & 0 & 0 & 0.05 & 0.04 & 0 & 0 & 0 & 0 & 0.01 & 0 & 0 & 0 \\
\hline 17 & 0 & 0 & 0 & 0 & 0 & 0 & 0 & 0 & 0 & 0 & 0 & 0 \\
\hline 18 & 0.67 & 0.55 & 0.45 & 0.33 & 1.43 & 0.85 & 0.42 & 0.28 & 0.28 & 0.14 & 2.21 & 1.43 \\
\hline 19 & 0.01 & 1.16 & 0 & 0.51 & 0.02 & 1.13 & 1.73 & 0.4 & 0.2 & 0.11 & 8.25 & 5.23 \\
\hline 20 & 0 & 0.81 & 0 & 0.36 & 0 & 0.73 & 2.04 & 0.7 & 12.65 & 1.5 & 2.26 & 0.83 \\
\hline 21 & 0.05 & 0.63 & 0.24 & 0.34 & 0.03 & 0.79 & 1.15 & 0.67 & 1.84 & 1.39 & 1.43 & 0.6 \\
\hline 22 & 0.04 & 0.54 & 0.83 & 0.86 & 0.04 & 0.73 & 0.46 & 0.53 & 1.29 & 1.33 & 0.55 & 0.46 \\
\hline 23 & 0 & 0 & 0 & 0 & 0 & 0 & 0 & 0 & 0.02 & 0.01 & 0 & 0 \\
\hline 24 & 0 & 0 & 0 & 0 & 0 & 0 & 0.01 & 0.67 & 0 & 1.83 & 0 & 0.52 \\
\hline 25 & 0.01 & 1.16 & 0.17 & 0.52 & 0.01 & 1.23 & 0.06 & 0.78 & 0.2 & 1.57 & 0.05 & 0.64 \\
\hline 26 & 0 & 0 & 0 & 0 & 0 & 0 & 0.29 & 0.71 & 0.28 & 1.98 & 0.22 & 0.6 \\
\hline 27 & 0 & 0 & 0 & 0 & 0 & 0 & 0.04 & 0.67 & 0.09 & 1.93 & 0.04 & 0.54 \\
\hline 28 & 0 & 0 & 0 & 0 & 0 & 0 & 0.03 & 0.68 & 0.06 & 1.64 & 0.02 & 0.55 \\
\hline 29 & 0 & 0 & 0 & 0 & 0 & 0 & 0.23 & 0.83 & 0.31 & 1.82 & 0.18 & 0.66 \\
\hline 30 & 0 & 0 & 0 & 0 & 0 & 0 & 0.04 & 0.87 & 0.03 & 2.51 & 0.03 & 0.67 \\
\hline 31 & 0.04 & 1.28 & 0.63 & 0.61 & 0.04 & 1.27 & 0.4 & 0.93 & 0.72 & 1.57 & 0.31 & 0.73 \\
\hline 32 & 0.11 & 1.14 & 0.1 & 0.7 & 0.1 & 1.22 & 0.22 & 0.79 & 0.32 & 1.09 & 0.16 & 0.66 \\
\hline 33 & 0.24 & 1.03 & 0.55 & 0.77 & 0.25 & 1 & 0.56 & 0.72 & 1.08 & 1.11 & 0.44 & 0.65 \\
\hline 34 & 0.01 & 1.4 & 0.02 & 0.68 & 0.01 & 1.15 & 0.03 & 1.03 & 0.06 & 1.38 & 0.04 & 0.84 \\
\hline 35 & 0.3 & 1.3 & 0.08 & 0.77 & 0.14 & 1.61 & 0.03 & 1.63 & 0.01 & 0.62 & 0.02 & 1.86 \\
\hline 36 & 0.43 & 1.22 & 0.12 & 0.53 & 0.14 & 1.99 & 0.09 & 3.43 & 0.04 & 0.97 & 0.05 & 9.27 \\
\hline 37 & 0.07 & 0.14 & 0.01 & 0.06 & 0.07 & 0.17 & 0.12 & 2.73 & 0.04 & 0.82 & 0.08 & 3.29 \\
\hline 38 & 0.44 & 0.25 & 0.04 & 0.03 & 1.26 & 0.63 & 0.39 & 0.83 & 0.12 & 0.5 & 0.41 & 0.88 \\
\hline 39 & 0.1 & 0.16 & 0.03 & 0.05 & 0.33 & 0.3 & 0.19 & 0.47 & 0.08 & 0.42 & 0.21 & 0.97 \\
\hline 40 & 0.68 & 1.42 & 0.22 & 0.62 & 0.28 & 1.4 & 0.11 & 1.17 & 0.05 & 0.77 & 0.12 & 1.43 \\
\hline 41 & 0 & 0.04 & 0 & 0.02 & 0 & 0.05 & 0.16 & 0.61 & 0.45 & 1.13 & 0.08 & 1.02 \\
\hline 42 & 0.09 & 0.25 & 0.03 & 0.1 & 0.05 & 0.25 & 0.04 & 0.45 & 0.02 & 0.3 & 0.04 & 1.24 \\
\hline 43 & 1.48 & 1.57 & 1.01 & 1.15 & 0.61 & 1.28 & 4.51 & 2.53 & 0.9 & 0.49 & 5.63 & 2.08 \\
\hline 44 & 0.98 & 1.53 & 0.15 & 0.65 & 0.6 & 1.4 & 0.4 & 1.12 & 0.08 & 0.75 & 0.24 & 1.26 \\
\hline 45 & 0.03 & 1.14 & 0.01 & 0.52 & 0.02 & 1.35 & 2.6 & 2.02 & 0.3 & 0.39 & 1.05 & 3.3 \\
\hline 46 & 0.12 & 0.63 & 0.01 & 0.28 & 0.04 & 0.74 & 0.12 & 0.65 & 0.06 & 0.47 & 0.02 & 1.15 \\
\hline 47 & 0.24 & 0.73 & 0.24 & 0.47 & 0.51 & 0.92 & 2.37 & 0.79 & 1.2 & 0.86 & 2.78 & 1.55 \\
\hline 48 & 0.03 & 0.69 & 0.03 & 0.27 & 0.22 & 0.83 & 1.92 & 1.81 & 0.51 & 0.71 & 1.08 & 1.52 \\
\hline 49 & -0.02 & 0.8 & 0.04 & 0.4 & 0.14 & 1 & 0.78 & 0.9 & 0.35 & 0.56 & 0.73 & 1.19 \\
\hline 50 & 1.36 & 1.14 & 0.91 & 0.81 & 1.57 & 1.37 & 0.12 & 0.23 & 0.12 & 0.48 & 0.11 & 0.52 \\
\hline 51 & 0.26 & 0.97 & 0.12 & 0.52 & 0.34 & 1.07 & 0.01 & 0.21 & 0.01 & 0.51 & 0.01 & 0.23 \\
\hline 52 & 0.15 & 0.79 & 0.2 & 0.81 & 0.42 & 1 & 0.01 & 0.66 & 0.03 & 1.44 & 0.01 & 0.73 \\
\hline 53 & 0.06 & 0.79 & 0.71 & 1.08 & 0.2 & 0.94 & 0.01 & 0.69 & 0.04 & 1.1 & 0.01 & 0.64 \\
\hline 54 & 0.39 & 0.88 & 0.23 & 0.57 & 0.39 & 1.05 & 1.1 & 0.64 & 0.84 & 0.97 & 1.27 & 0.86 \\
\hline 55 & 1.44 & 0.98 & 1.97 & 1.47 & 2.07 & 1.22 & 1.42 & 0.7 & 0.79 & 0.78 & 1.82 & 0.97 \\
\hline 56 & 0.05 & 0.62 & 2.61 & 2.17 & 0.03 & 0.72 & 0.46 & 0.82 & 2.94 & 1.74 & 0.47 & 0.76 \\
\hline 57 & 0.97 & 0.72 & 4.31 & 3.13 & 0.45 & 0.49 & 3.81 & 0.55 & 4.97 & 0.91 & 4.17 & 0.63 \\
\hline 58 & 0 & 0.69 & 0 & 0.25 & 0 & 0.78 & 0 & 1.75 & 0 & 1.06 & 0 & 0.92 \\
\hline 59 & 0.77 & 0.8 & 1.09 & 1.03 & 1.01 & 0.95 & 0.51 & 0.66 & 0.49 & 1.02 & 0.6 & 0.74 \\
\hline 60 & 0.02 & 0.55 & 0.01 & 0.31 & 0.02 & 0.65 & 0.04 & 0.73 & 0.03 & 0.98 & 0.05 & 0.77 \\
\hline 61 & 0 & 0.57 & 1.92 & 1.96 & 0.01 & 0.61 & 0 & 0.48 & 1.01 & 1.18 & 0.01 & 0.49 \\
\hline 62 & 0 & 0.57 & 0.03 & 0.44 & 0.01 & 0.61 & 0.54 & 0.49 & 0.54 & 0.92 & 1.93 & 0.55 \\
\hline 63 & 0.13 & 0.94 & 0.85 & 1.24 & 0.17 & 0.95 & 5.38 & 1.09 & 4.66 & 1.63 & 5.06 & 1.02 \\
\hline 64 & 0.69 & 0.92 & 0.45 & 0.51 & 1.26 & 1.25 & 3.99 & 0.86 & 2.55 & 1.19 & 4.46 & 1.64 \\
\hline 65 & 0.04 & 0.67 & 0.17 & 0.48 & 0.04 & 0.75 & 1.59 & 0.67 & 0.73 & 0.97 & 1.16 & 0.77 \\
\hline 66 & 0.01 & 0.66 & 0.13 & 0.46 & 0.01 & 0.73 & 0 & 0 & 0 & 0 & 0 & 0 \\
\hline 67 & 0.05 & 0.7 & 0.04 & 0.39 & 0.07 & 0.74 & 1.67 & 0.69 & 0.15 & 1.13 & 0.99 & 0.92 \\
\hline 68 & 0.11 & 0.81 & 0.98 & 1.21 & 0.1 & 0.81 & 0.05 & 0.65 & 0.43 & 1.35 & 0.02 & 0.61 \\
\hline 69 & 1.48 & 0.98 & 5.97 & 4.83 & 1.63 & 1.28 & 0.68 & 0.66 & 8.54 & 4.91 & 0.3 & 0.72 \\
\hline 70 & 0.05 & 0.88 & 1.67 & 2.32 & 0.05 & 0.97 & 0.12 & 0.65 & 1.54 & 1.94 & 0.05 & 0.67 \\
\hline
\end{tabular}


Table A1. Cont.

\begin{tabular}{|c|c|c|c|c|c|c|c|c|c|c|c|c|}
\hline 71 & 0.15 & 0.76 & 0.42 & 0.69 & 0.17 & 0.8 & 1.17 & 0.73 & 1.35 & 1.83 & 0.75 & 0.77 \\
\hline 72 & 0.07 & 0.45 & 10.32 & 8.7 & 0.39 & 0.64 & 6.11 & 0.59 & 19.81 & 6.65 & 4.39 & 1.14 \\
\hline 73 & 0.04 & 0.49 & 5.4 & 4.81 & 0.25 & 0.61 & 1.34 & 0.6 & 3.6 & 3.67 & 0.99 & 0.77 \\
\hline 74 & 0.02 & 0.45 & 0.08 & 0.22 & 0.03 & 0.51 & 0.45 & 0.75 & 0.53 & 1.37 & 0.28 & 0.59 \\
\hline 75 & 0 & 0 & 0 & 0 & 0 & 0 & 0 & 0 & 0 & 0 & 0 & 0 \\
\hline 76 & 0.21 & 0.62 & 1.46 & 1.64 & 0.29 & 0.75 & 1.22 & 0.7 & 1.22 & 2.05 & 0.87 & 0.64 \\
\hline 77 & 0.01 & 0.62 & 0.07 & 0.71 & 0.02 & 0.77 & 0.03 & 0.7 & 0.03 & 1.09 & 0.03 & 0.57 \\
\hline 78 & 0 & 0.41 & 0.08 & 0.57 & 0 & 0.49 & 0.32 & 0.53 & 0.23 & 0.99 & 0.17 & 0.44 \\
\hline 79 & 0 & 0.42 & 0.04 & 0.56 & 0 & 0.5 & 0.03 & 0.53 & 0.02 & 0.84 & 0.02 & 0.42 \\
\hline 80 & 0.14 & 0.52 & 0.14 & 0.41 & 0.18 & 0.61 & 0.8 & 0.49 & 0.52 & 0.99 & 0.43 & 0.43 \\
\hline 81 & 0.02 & 0.51 & 0.03 & 0.42 & 0.03 & 0.58 & 0.11 & 0.48 & 0.12 & 1.03 & 0.06 & 0.4 \\
\hline 82 & 0.13 & 0.82 & 4.23 & 3.57 & 0.15 & 0.8 & 0.68 & 0.88 & 0.93 & 1.41 & 0.42 & 0.67 \\
\hline 83 & 0 & 0 & 0 & 0 & 0 & 0 & 0 & 0 & 0 & 0 & 0 & 0 \\
\hline 84 & 0.41 & 0.56 & 2.17 & 1.35 & 0.43 & 0.65 & 0.56 & 0.78 & 0.66 & 1.86 & 0.36 & 0.73 \\
\hline 85 & 2.78 & 1.46 & 1.12 & 0.62 & 3.31 & 1.76 & 3.04 & 1.06 & 2.62 & 2.69 & 2.28 & 1.14 \\
\hline 86 & 2.62 & 1.64 & 1.29 & 0.66 & 3.27 & 1.97 & 8.01 & 4.06 & 4.51 & 1.85 & 4.39 & 1.84 \\
\hline 87 & 0.03 & 0.85 & 0 & 0.31 & 0.04 & 0.89 & 1.58 & 1.19 & 1.35 & 0.68 & 1.21 & 0.91 \\
\hline 88 & 1.38 & 1.09 & 1.08 & 0.68 & 1.61 & 1.32 & 4.69 & 2.2 & 3.76 & 1.72 & 2.48 & 1.18 \\
\hline 89 & 0.55 & 0.88 & 0.14 & 0.41 & 0.71 & 1.03 & 1.52 & 1.07 & 0.62 & 0.75 & 1.42 & 1.06 \\
\hline 90 & 0.55 & 0.85 & 0.16 & 0.32 & 0.82 & 1.1 & 0.43 & 0.77 & 0.2 & 0.73 & 0.44 & 0.73 \\
\hline 91 & 1.23 & 1.02 & 0.31 & 0.37 & 1.15 & 1.04 & 4.12 & 3.36 & 1.79 & 1.62 & 2.28 & 1.65 \\
\hline 92 & 0.62 & 0.81 & 0.3 & 0.36 & 0.48 & 0.85 & 2.49 & 2.23 & 1.12 & 1.87 & 1.74 & 1.15 \\
\hline 93 & 1.14 & 1.19 & 0.33 & 0.49 & 1.39 & 1.4 & 2.96 & 1.81 & 1.06 & 0.93 & 2.18 & 1.77 \\
\hline 94 & 0.06 & 0.72 & 0.79 & 0.59 & 0.12 & 0.79 & 0.78 & 0.07 & 1.26 & 0.15 & 0.62 & 0.1 \\
\hline 95 & 0 & 0 & 0.03 & 0.02 & 0 & 0 & 0 & 0 & 0 & 0 & 0 & 0 \\
\hline 96 & 0.11 & 0.68 & 7.29 & 8.02 & 0.11 & 0.61 & 3.21 & 0.87 & 27.36 & 9.79 & 2.76 & 0.75 \\
\hline 97 & 0.35 & 0.46 & 11.04 & 10.03 & 0.23 & 0.33 & 0.05 & 0.5 & 0.57 & 1.19 & 0.04 & 0.41 \\
\hline 98 & 0 & 0 & 0 & 0 & 0 & 0 & 0.07 & 0.33 & 0.08 & 0.2 & 0.06 & 0.25 \\
\hline 99 & 0.51 & 0.68 & 2.83 & 2.13 & 0.48 & 0.61 & 0.57 & 0.44 & 0.64 & 0.3 & 0.47 & 0.31 \\
\hline 100 & 0.02 & 0.68 & 0.05 & 2.23 & 0.02 & 0.56 & 0.01 & 0.4 & 0.01 & 0.28 & 0.01 & 0.28 \\
\hline 101 & 0.06 & 0.62 & 1.25 & 4.58 & 0.04 & 0.42 & 0.06 & 0.59 & 0.33 & 0.96 & 0.04 & 0.49 \\
\hline 102 & 0.17 & 0.75 & 1.46 & 5.3 & 0.12 & 0.48 & 0 & 0.87 & 0 & 0.54 & 0 & 0.63 \\
\hline 103 & 0 & 0.72 & 0 & 2.37 & 0 & 0.6 & 0 & 0.53 & 0 & 0.33 & 0 & 0.36 \\
\hline 104 & 0 & 0 & 0 & 0 & 0 & 0 & 0 & 0 & 0 & 0 & 0 & 0 \\
\hline 105 & 0 & 0 & 0 & 0 & 0 & 0 & 0 & 0 & 0 & 0 & 0 & 0 \\
\hline 106 & 0 & 0.72 & 0 & 4.97 & 0 & 0.44 & 0 & 0.54 & 0 & 0.36 & 0 & 0.37 \\
\hline 107 & 0.02 & 0.49 & 0.11 & 1.91 & 0.02 & 0.4 & 0.02 & 0.5 & 0.02 & 0.55 & 0.02 & 0.37 \\
\hline 108 & 1.43 & 1.04 & 4.27 & 1.35 & 0.93 & 0.65 & 0.66 & 0.94 & 0.74 & 6.81 & 0.51 & 0.7 \\
\hline 109 & 3.53 & 1.38 & 5.82 & 1.36 & 2.1 & 0.72 & 1.85 & 1.09 & 1.6 & 6.83 & 1.28 & 0.7 \\
\hline 110 & 1.58 & 0.91 & 19.23 & 6.8 & 0.87 & 0.51 & 0.24 & 0.63 & 0.31 & 1.08 & 0.15 & 0.49 \\
\hline 111 & 0.21 & 0.77 & 4.58 & 8.73 & 0.11 & 0.46 & 0.08 & 0.39 & 3.09 & 1.5 & 0.09 & 0.36 \\
\hline 112 & 0.24 & 0.92 & 0.13 & 0.47 & 0.28 & 0.88 & 0.19 & 0.66 & 0.19 & 2.36 & 0.12 & 0.49 \\
\hline 113 & 17.65 & 7.35 & 5.1 & 2.71 & 11.02 & 4.55 & 18.15 & 14.09 & 0.8 & 1.75 & 5.31 & 4.05 \\
\hline 114 & 0.03 & 0.11 & 0.08 & 0.12 & 0.03 & 0.12 & 0 & 0 & 0 & 0 & 0 & 0 \\
\hline 115 & 2.45 & 1.66 & 0.58 & 0.4 & 2.85 & 1.74 & 0.78 & 1.24 & 0.26 & 0.57 & 1.29 & 1.39 \\
\hline 116 & 0.2 & 1.47 & 0.14 & 0.42 & 0.21 & 1.63 & 0.05 & 0.97 & 0.05 & 0.59 & 0.06 & 0.61 \\
\hline 117 & 8.3 & 3.38 & 4.21 & 1.02 & 8.7 & 3.34 & 2.4 & 0.97 & 1.82 & 0.25 & 3.04 & 1.44 \\
\hline 118 & 5.52 & 3.04 & 2.44 & 0.7 & 10.26 & 4.8 & 1.83 & 1.26 & 1.14 & 0.56 & 3.36 & 2.09 \\
\hline 119 & 7.41 & 4.13 & 1.05 & 0.48 & 7.35 & 3.78 & 3.3 & 2.18 & 1.3 & 0.55 & 3.5 & 2.59 \\
\hline 120 & 0.97 & 1.11 & 0.65 & 0.63 & 0.52 & 0.85 & 0.6 & 0.71 & 0.85 & 0.7 & 0.49 & 0.56 \\
\hline 121 & 2.42 & 1.49 & 2.66 & 1.41 & 4.12 & 2.18 & 1.64 & 0.87 & 1.09 & 0.72 & 1.96 & 1.17 \\
\hline 122 & 0.09 & 2.32 & 0.89 & 1.49 & 0.19 & 1.99 & 0.07 & 1.92 & 0.29 & 1.13 & 0.09 & 0.97 \\
\hline 123 & 0.01 & 1.18 & 0.04 & 0.46 & 0 & 0.91 & 0.58 & 0.83 & 1.12 & 0.76 & 0.62 & 0.68 \\
\hline 124 & 0.01 & 1.06 & 0.07 & 0.61 & 0.02 & 1.28 & 0.04 & 0.9 & 0.36 & 0.74 & 0.04 & 0.65 \\
\hline 125 & 1.08 & 1.48 & 5.88 & 5.12 & 0.66 & 1.15 & 0.69 & 1.34 & 0.79 & 1.08 & 0.66 & 1.11 \\
\hline 126 & 3.51 & 2.76 & 3.59 & 1.44 & 3.24 & 2.3 & 2.66 & 1.08 & 1.99 & 0.46 & 2.89 & 1.26 \\
\hline 127 & 3.38 & 1.73 & 1.71 & 0.98 & 3.27 & 1.64 & 0.15 & 1.12 & 0.19 & 0.56 & 0.34 & 0.75 \\
\hline 128 & 4.33 & 1.46 & 1.8 & 0.3 & 4.88 & 1.84 & 2.28 & 0.44 & 3.77 & 0.18 & 2.39 & 0.34 \\
\hline 129 & 2.54 & 1.7 & 0.39 & 0.3 & 1.27 & 1.28 & 1.45 & 1.28 & 0.46 & 0.29 & 0.81 & 0.5 \\
\hline 130 & 1.08 & 0.85 & 0.32 & 0.3 & 1.44 & 1.26 & 0.57 & 0.67 & 0.41 & 0.24 & 0.47 & 0.5 \\
\hline
\end{tabular}


Table A1. Cont.

\begin{tabular}{|c|c|c|c|c|c|c|c|c|c|c|c|c|}
\hline 131 & 15.44 & 6.9 & 1.92 & 0.59 & 5.93 & 1.66 & 3.69 & 2.62 & 0.54 & 0.2 & 0.9 & 0.3 \\
\hline 132 & 1.71 & 0.8 & 0.89 & 0.33 & 1.56 & 0.7 & 0.33 & 0.96 & 0.28 & 0.66 & 0.24 & 0.75 \\
\hline 133 & 2.32 & 1.69 & 0.42 & 0.32 & 2.11 & 1.54 & 2.34 & 1.43 & 1 & 0.44 & 1.05 & 0.44 \\
\hline 134 & 0.08 & 1.02 & 0.16 & 0.41 & 0.38 & 1.41 & 0.3 & 0.75 & 0.18 & 0.6 & 0.22 & 0.62 \\
\hline 135 & 9.26 & 1.86 & 4.95 & 0.76 & 17.23 & 5.59 & 2.64 & 1.2 & 1.89 & 0.62 & 2.27 & 0.81 \\
\hline 136 & 10.38 & 5.95 & 0.41 & 0.48 & 6.84 & 3.78 & 4.09 & 3.84 & 0.13 & 0.46 & 1.43 & 1.51 \\
\hline 137 & 7.64 & 4.11 & 0.31 & 0.29 & 6.59 & 3.33 & 3.8 & 3.23 & 0.26 & 0.52 & 2.3 & 1.85 \\
\hline 138 & 11.15 & 6.12 & 0.37 & 0.47 & 10.39 & 5.39 & 3.31 & 3.37 & 0.34 & 0.82 & 0.83 & 1.14 \\
\hline 139 & 0.07 & 0.81 & 0.08 & 0.4 & 0.09 & 0.78 & 0.03 & 0.86 & 0.02 & 0.65 & 0.09 & 0.69 \\
\hline 140 & 0.1 & 0.8 & 0.09 & 0.4 & 0.12 & 0.78 & 0.03 & 0.86 & 0.02 & 0.65 & 0.09 & 0.69 \\
\hline 141 & 0.17 & 0.79 & 0.13 & 0.4 & 0.21 & 0.79 & 0.01 & 0.85 & 0.01 & 0.64 & 0.02 & 0.65 \\
\hline 142 & 0.52 & 0.83 & 0.33 & 0.43 & 0.63 & 0.88 & 0 & 0.85 & 0 & 0.64 & 0.01 & 0.64 \\
\hline 143 & 0.02 & 0.79 & 0.05 & 0.4 & 0.02 & 0.76 & 0.01 & 0.85 & 0.01 & 0.64 & 0.02 & 0.65 \\
\hline 144 & 0.03 & 0.8 & 0.05 & 0.4 & 0.04 & 0.77 & 0.01 & 0.85 & 0.01 & 0.64 & 0.02 & 0.65 \\
\hline 145 & 0.1 & 0.8 & 0.09 & 0.4 & 0.13 & 0.79 & 0.01 & 0.85 & 0.01 & 0.65 & 0.02 & 0.65 \\
\hline 146 & 0.01 & 0.8 & 0.04 & 0.39 & 0.02 & 0.77 & 0 & 0 & 0 & 0 & 0 & 0 \\
\hline 147 & 0 & 0.8 & 0.04 & 0.39 & 0 & 0.77 & 0 & 0 & 0 & 0 & 0 & 0 \\
\hline 148 & 0.01 & 0.8 & 0.04 & 0.39 & 0.01 & 0.77 & 0 & 0 & 0 & 0 & 0 & 0 \\
\hline 149 & 0.42 & 0.82 & 0.28 & 0.45 & 0.51 & 0.85 & 0.01 & 0.84 & 0.01 & 0.86 & 0.02 & 0.65 \\
\hline 150 & 0 & 0.79 & 0.04 & 0.4 & 0 & 0.76 & 0 & 0.85 & 0 & 0.64 & 0 & 0.64 \\
\hline 151 & 0.03 & 0.81 & 0.1 & 0.44 & 0.04 & 0.78 & 0.09 & 0.89 & 0.09 & 0.66 & 0.32 & 0.83 \\
\hline 152 & 0.07 & 0.81 & 0.12 & 0.44 & 0.08 & 0.78 & 0.17 & 0.93 & 0.16 & 0.67 & 0.57 & 0.98 \\
\hline 153 & 0.01 & 0.8 & 0.04 & 0.39 & 0.01 & 0.77 & 0.08 & 0.89 & 0.08 & 0.48 & 0.29 & 0.81 \\
\hline 154 & 0.01 & 0.81 & 0.04 & 0.39 & 0.02 & 0.77 & 0.03 & 0.86 & 0.03 & 0.47 & 0.12 & 0.71 \\
\hline 155 & 0 & 0.81 & 0.04 & 0.38 & 0 & 0.77 & 0.03 & 0.86 & 0.03 & 0.47 & 0.1 & 0.7 \\
\hline 156 & 0.03 & 0.81 & 0.06 & 0.39 & 0.04 & 0.78 & 0.03 & 0.86 & 0.03 & 0.47 & 0.1 & 0.7 \\
\hline 157 & 0 & 0.81 & 0.04 & 0.38 & 0 & 0.77 & 0.01 & 0.85 & 0.01 & 0.46 & 0.04 & 0.66 \\
\hline 158 & 0.01 & 0.81 & 0.04 & 0.38 & 0.01 & 0.77 & 0.01 & 0.86 & 0.01 & 0.46 & 0.05 & 0.67 \\
\hline 159 & 1.56 & 1.65 & 0.28 & 0.57 & 1.29 & 1.55 & 0.58 & 1.23 & 0.04 & 0.4 & 2.13 & 2.19 \\
\hline 160 & 2.91 & 2.03 & 0.62 & 0.55 & 2.8 & 1.88 & 0.79 & 1.19 & 0.31 & 0.51 & 2.59 & 2.2 \\
\hline 161 & 1.29 & 1.41 & 0.15 & 0.32 & 1.67 & 1.34 & 1.79 & 1.44 & 1.21 & 0.52 & 3.84 & 2.44 \\
\hline 162 & 0.04 & 0.02 & 0.04 & 0.04 & 0.26 & 0.13 & 0.24 & 1.19 & 0.04 & 1.19 & 0.85 & 1.21 \\
\hline \multirow[t]{3}{*}{163} & 0 & 0 & 0.04 & 0.03 & 0 & 0 & 0 & 0 & 0 & 0 & 0 & 0 \\
\hline & \multicolumn{6}{|c|}{ France } & \multicolumn{6}{|c|}{ Germany } \\
\hline & \multicolumn{2}{|c|}{ Final Demand } & \multicolumn{2}{|c|}{$\mathrm{CO}_{2}$} & \multicolumn{2}{|c|}{ Employment } & \multicolumn{2}{|c|}{ Final Demand } & \multicolumn{2}{|c|}{$\mathrm{CO}_{2}$} & \multicolumn{2}{|c|}{ Employment } \\
\hline Sector ID & Fwd & Bckwd & Fwd & Bckwd & Fwd & Bckwd & Fwd & Bckwd & Fwd & Bckwd & Fwd & Bckwd \\
\hline 1 & 0 & 0.03 & 0.04 & 0.06 & 0 & 0.03 & 0 & 0 & 0 & 0 & 0 & 0 \\
\hline 2 & 0.27 & 0.66 & 1.02 & 1.3 & 0.7 & 0.89 & 0.15 & 0.73 & 0.03 & 0.44 & 0.22 & 0.88 \\
\hline 3 & 0.21 & 0.39 & 0.99 & 1.06 & 0.36 & 0.47 & 0.14 & 0.71 & 0.1 & 0.53 & 0.25 & 0.89 \\
\hline 4 & 1.15 & 0.89 & 1.14 & 1.12 & 1.71 & 1.04 & 0.28 & 0.61 & 0.04 & 0.41 & 0.54 & 0.8 \\
\hline 5 & 0.11 & 0.41 & 0.52 & 0.75 & 0.3 & 0.5 & 0.06 & 0.57 & 0.01 & 0.37 & 0.28 & 0.75 \\
\hline 6 & 0.05 & 0.47 & 0.18 & 0.56 & 0.16 & 0.52 & 0.03 & 0.7 & 0.01 & 0.42 & 0.08 & 0.86 \\
\hline 7 & 0.01 & 0.03 & 0.04 & 0.05 & 0 & 0.03 & 0 & 0 & 0 & 0 & 0 & 0 \\
\hline 8 & 0.23 & 0.24 & 0.32 & 0.32 & 0.24 & 0.26 & 0.15 & 1.06 & 0.05 & 0.72 & 0.4 & 1.21 \\
\hline 9 & 0.27 & 1.07 & 0.44 & 1.26 & 0.13 & 1.13 & 0.12 & 1.44 & 0.01 & 1.12 & 0.25 & 2.04 \\
\hline 10 & 0.12 & 1.08 & 0.1 & 1.17 & 0.09 & 1.18 & 0.3 & 1.11 & 0.06 & 0.9 & 0.22 & 1.49 \\
\hline 11 & 0.24 & 1.16 & 0.09 & 1.2 & 0.08 & 1.18 & 0.14 & 0.56 & 0.01 & 0.5 & 0.12 & 0.59 \\
\hline 12 & 0.12 & 0.17 & 0.08 & 0.18 & 0.06 & 0.17 & 0.04 & 0.08 & 0.02 & 0.05 & 0.03 & 0.08 \\
\hline 13 & 0.01 & 0.05 & 0.04 & 0.08 & 0 & 0.05 & 0.02 & 0.06 & 0.01 & 0.03 & 0.02 & 0.05 \\
\hline 14 & 0.41 & 0.99 & 0.37 & 1.01 & 0.81 & 1.23 & 0.39 & 0.62 & 0.07 & 0.42 & 0.34 & 0.78 \\
\hline 15 & 0 & 0.54 & 0.04 & 0.49 & 0 & 0.57 & 0 & 0.62 & 0 & 0.48 & 0 & 1.01 \\
\hline 16 & 0 & 0 & 0.09 & 0.07 & 0 & 0 & 0 & 0 & 0.01 & 0.01 & 0 & 0 \\
\hline 17 & 0 & 0 & 0.04 & 0.03 & 0 & 0 & 0 & 0 & 0 & 0 & 0 & 0 \\
\hline 18 & 0.36 & 0.44 & 0.26 & 0.45 & 0.3 & 0.46 & 0.14 & 0.44 & 0.05 & 0.24 & 0.2 & 0.56 \\
\hline 19 & 0.09 & 0.38 & 0.27 & 0.73 & 0.13 & 0.46 & 0.02 & 0.43 & 0.02 & 1.02 & 0.02 & 0.41 \\
\hline 20 & 0 & 1.47 & 0.08 & 0.85 & 0 & 2.38 & 0.14 & 1.5 & 4.39 & 1.92 & 0.21 & 1.33 \\
\hline 21 & 0.02 & 0.68 & 0.07 & 0.42 & 0.01 & 0.83 & 0.02 & 0.67 & 0.05 & 0.6 & 0.01 & 0.93 \\
\hline 22 & 0 & 0.63 & 0 & 0.4 & 0 & 0.82 & 0.11 & 0.69 & 0.06 & 0.61 & 0.02 & 0.9 \\
\hline 23 & 0 & 0 & 0 & 0 & 0 & 0 & 0 & 0.48 & 0 & 0.38 & 0 & 0.99 \\
\hline
\end{tabular}


Table A1. Cont.

\begin{tabular}{|c|c|c|c|c|c|c|c|c|c|c|c|c|}
\hline 24 & 0 & 0 & 0 & 0 & 0 & 0 & 0 & 0.83 & 0 & 0.78 & 0 & 1 \\
\hline 25 & 0 & 0 & 0 & 0 & 0 & 0 & 0 & 0.88 & 0 & 0.81 & 0 & 0.96 \\
\hline 26 & 0 & 0 & 0 & 0 & 0 & 0 & 0 & 0 & 0 & 0 & 0 & 0 \\
\hline 27 & 0 & 0 & 0 & 0 & 0 & 0 & 0 & 0 & 0 & 0 & 0 & 0 \\
\hline 28 & 0 & 1.54 & 0 & 1.33 & 0 & 1.42 & 0 & 0 & 0 & 0 & 0 & 0 \\
\hline 29 & 0 & 0 & 0.02 & 0.02 & 0 & 0 & 0 & 0 & 0 & 0 & 0 & 0 \\
\hline 30 & 0 & 0 & 0 & 0 & 0 & 0 & 0 & 0.84 & 0.01 & 0.84 & 0 & 0.91 \\
\hline 31 & 0 & 2.53 & 0 & 1.42 & 0 & 1.88 & 0 & 0.88 & 0 & 0.79 & 0 & 0.9 \\
\hline 32 & 0.19 & 0.67 & 0.57 & 0.63 & 0.22 & 0.75 & 0.08 & 0.69 & 0.13 & 0.7 & 0.09 & 0.96 \\
\hline 33 & 0.07 & 0.61 & 0.35 & 0.68 & 0.09 & 0.63 & 0.09 & 0.64 & 0.27 & 0.8 & 0.12 & 0.75 \\
\hline 34 & 0.02 & 0.9 & 0.05 & 0.78 & 0.01 & 0.93 & 0.02 & 0.89 & 0.05 & 0.81 & 0.02 & 0.88 \\
\hline 35 & 0.44 & 1.27 & 0.13 & 1.11 & 0.22 & 1.35 & 0.15 & 1.09 & 0.02 & 0.78 & 0.09 & 2.03 \\
\hline 36 & 0.32 & 1.61 & 0.14 & 1.43 & 0.14 & 2.98 & 0.58 & 1.68 & 0.15 & 0.86 & 0.22 & 1.24 \\
\hline 37 & 0.31 & 1.51 & 0.09 & 1.3 & 0.06 & 1.96 & 0.1 & 0.11 & 0.02 & 0.06 & 0.02 & 0.08 \\
\hline 38 & 0.61 & 1.69 & 0.07 & 1.27 & 0.05 & 1.5 & 0.64 & 0.34 & 0.03 & 0.04 & 1.53 & 0.61 \\
\hline 39 & 0.07 & 0.09 & 0.09 & 0.12 & 0.25 & 0.17 & 0.2 & 0.77 & 0.03 & 0.37 & 0.26 & 0.87 \\
\hline 40 & 0.94 & 1.47 & 0.58 & 1.33 & 0.5 & 1.38 & 0.87 & 1.26 & 0.14 & 0.83 & 0.26 & 0.96 \\
\hline 41 & 0.01 & 0.02 & 0.06 & 0.06 & 0.03 & 0.04 & 0 & 0.04 & 0 & 0.02 & 0.01 & 0.05 \\
\hline 42 & 0.22 & 0.3 & 0.15 & 0.31 & 0.56 & 0.55 & 0.17 & 0.43 & 0.02 & 0.24 & 0.28 & 0.52 \\
\hline 43 & 1.56 & 1.24 & 1.79 & 1.83 & 0.76 & 1.03 & 2.34 & 1.93 & 0.75 & 1.21 & 0.49 & 1.57 \\
\hline 44 & 1.23 & 1.43 & 0.47 & 1.1 & 0.95 & 1.44 & 0.87 & 1.33 & 0.14 & 0.92 & 0.33 & 0.99 \\
\hline 45 & 0.21 & 1.16 & 0.1 & 1.02 & 0.11 & 1.27 & 0.12 & 0.98 & 0.02 & 0.63 & 0.03 & 0.93 \\
\hline 46 & 0.04 & 0.47 & 0.06 & 0.35 & 0.01 & 0.62 & 0.16 & 0.8 & 0.01 & 0.46 & 0.03 & 1.03 \\
\hline 47 & 0.27 & 0.8 & 0.3 & 0.71 & 0.44 & 1.06 & 0.27 & 0.73 & 0.13 & 0.67 & 0.38 & 0.78 \\
\hline 48 & 0.26 & 0.95 & 0.05 & 0.65 & 0.23 & 1.17 & 0.41 & 0.9 & 0.03 & 0.47 & 0.16 & 0.77 \\
\hline 49 & 0 & 0.72 & 0.03 & 0.69 & 0.11 & 0.9 & 0.06 & 0.69 & 0.03 & 0.5 & 0.08 & 0.72 \\
\hline 50 & 0.46 & 0.86 & 0.32 & 0.67 & 0.69 & 1.07 & 0.72 & 0.87 & 0.32 & 0.66 & 0.89 & 0.92 \\
\hline 51 & 0.04 & 0.81 & 0.04 & 0.64 & 0.07 & 0.97 & 0.04 & 0.79 & 0.02 & 0.63 & 0.05 & 0.78 \\
\hline 52 & 0.11 & 0.88 & 0.14 & 0.75 & 0.21 & 1.15 & 0.1 & 0.7 & 0.12 & 0.98 & 0.24 & 0.81 \\
\hline 53 & 0.08 & 0.9 & 0.27 & 0.81 & 0.17 & 1.23 & 0.06 & 0.75 & 0.23 & 0.84 & 0.18 & 0.89 \\
\hline 54 & 0.45 & 1.02 & 0.33 & 0.8 & 0.49 & 1.19 & 0.43 & 0.77 & 0.21 & 0.58 & 0.49 & 0.81 \\
\hline 55 & 1.45 & 1.08 & 1.48 & 1.22 & 2.02 & 1.44 & 1.8 & 1.29 & 1.25 & 1.05 & 2.38 & 1.45 \\
\hline 56 & 0.03 & 0.34 & 2.39 & 1.98 & 0.03 & 0.37 & 0.02 & 0.8 & 1.14 & 1.87 & 0.03 & 0.75 \\
\hline 57 & 2.38 & 0.89 & 6.73 & 3.89 & 1.25 & 0.4 & 1.96 & 1.31 & 3.7 & 2.76 & 0.89 & 0.76 \\
\hline 58 & 0 & 1.39 & 0.02 & 0.98 & 0.03 & 1.16 & 0 & 0.65 & 0 & 0.39 & 0 & 0.59 \\
\hline 59 & 0.93 & 1.05 & 3.52 & 3.08 & 0.78 & 1.08 & 1.59 & 1.13 & 1.57 & 1.46 & 1.77 & 1.25 \\
\hline 60 & 0.01 & 0.76 & 0.24 & 0.83 & 0.01 & 0.98 & 0.02 & 0.63 & 0.02 & 0.47 & 0.02 & 0.87 \\
\hline 61 & 0 & 0.75 & 1.13 & 1.45 & 0 & 1.01 & 0 & 0.63 & 0.67 & 1.1 & 0 & 0.86 \\
\hline 62 & 0.01 & 0.75 & 0.05 & 0.62 & 0.01 & 1.01 & 0.02 & 0.63 & 0.15 & 0.65 & 0.04 & 0.85 \\
\hline 63 & 1.18 & 1.57 & 1.83 & 1.92 & 0.42 & 1.33 & 0.37 & 1.19 & 0.49 & 0.98 & 0.24 & 1.14 \\
\hline 64 & 1.05 & 1.04 & 1.19 & 1.39 & 1.54 & 1.42 & 1.21 & 0.99 & 0.89 & 1.02 & 1.91 & 1.39 \\
\hline 65 & 0.08 & 0.79 & 0.95 & 1.32 & 0.12 & 1 & 0.2 & 0.79 & 0.73 & 1.08 & 0.28 & 0.93 \\
\hline 66 & 0.04 & 0.77 & 0.3 & 0.79 & 0.07 & 1.01 & 0.05 & 0.8 & 0.23 & 0.75 & 0.09 & 0.97 \\
\hline 67 & 0.09 & 0.76 & 0.22 & 0.82 & 0.12 & 0.87 & 0.12 & 0.64 & 0.07 & 0.54 & 0.13 & 0.67 \\
\hline 68 & 0.09 & 0.75 & 0.61 & 1.1 & 0.1 & 0.9 & 0.08 & 0.7 & 0.27 & 0.78 & 0.09 & 0.8 \\
\hline 69 & 0.83 & 0.85 & 7.36 & 6.15 & 0.85 & 1.2 & 0.66 & 0.83 & 3.68 & 3.84 & 0.68 & 1.07 \\
\hline 70 & 0.01 & 0.85 & 0.59 & 2.25 & 0.01 & 1.12 & 0.03 & 0.8 & 0.41 & 1.41 & 0.03 & 1 \\
\hline 71 & 0.13 & 0.77 & 0.7 & 1.01 & 0.14 & 0.92 & 0.22 & 0.77 & 0.42 & 0.96 & 0.21 & 0.87 \\
\hline 72 & 0.31 & 0.79 & 9.67 & 7.65 & 0.53 & 1.07 & 0.45 & 0.5 & 9.07 & 8.21 & 0.91 & 0.75 \\
\hline 73 & 0.07 & 0.74 & 2.44 & 2.83 & 0.13 & 0.96 & 0.12 & 0.56 & 2.2 & 3.33 & 0.24 & 0.7 \\
\hline 74 & 0.01 & 0.96 & 0.03 & 0.58 & 0.01 & 1 & 0.01 & 0.46 & 0.02 & 0.4 & 0.02 & 0.5 \\
\hline 75 & 0 & 0 & 0 & 0 & 0 & 0 & 0 & 0 & 0 & 0 & 0 & 0 \\
\hline 76 & 0.08 & 0.92 & 0.48 & 1.02 & 0.1 & 1.21 & 0.11 & 0.58 & 0.48 & 1.28 & 0.17 & 0.72 \\
\hline 77 & 0.01 & 0.89 & 0.02 & 0.7 & 0.01 & 1.25 & 0.02 & 0.6 & 0.04 & 0.5 & 0.03 & 0.77 \\
\hline 78 & 0 & 0.54 & 0.04 & 0.43 & 0 & 0.67 & 0.01 & 0.41 & 0.08 & 0.41 & 0.02 & 0.49 \\
\hline 79 & 0 & 0.45 & 0.04 & 0.36 & 0 & 0.58 & 0 & 0.39 & 0.02 & 0.34 & 0.01 & 0.47 \\
\hline 80 & 0.08 & 0.67 & 0.16 & 0.48 & 0.13 & 0.73 & 0.06 & 0.42 & 0.12 & 0.48 & 0.15 & 0.47 \\
\hline 81 & 0 & 0 & 0 & 0 & 0 & 0 & 0.01 & 0.42 & 0.02 & 0.52 & 0.02 & 0.45 \\
\hline 82 & 0 & 1.24 & 0.01 & 0.73 & 0 & 1.03 & 0.02 & 0.73 & 0.04 & 0.59 & 0.03 & 0.6 \\
\hline 83 & 0 & 0 & 0 & 0 & 0 & 0 & 0 & 0 & 0 & 0 & 0 & 0 \\
\hline
\end{tabular}


Table A1. Cont.

\begin{tabular}{|c|c|c|c|c|c|c|c|c|c|c|c|c|}
\hline 84 & 0.27 & 0.86 & 1.21 & 1.36 & 0.29 & 1.06 & 0.34 & 0.54 & 1.04 & 1.09 & 0.42 & 0.64 \\
\hline 85 & 2.56 & 1.09 & 2.52 & 1.24 & 3.41 & 1.54 & 2.91 & 1.14 & 2 & 1.15 & 4.21 & 1.58 \\
\hline 86 & 1.75 & 1.33 & 0.98 & 1 & 1.92 & 1.54 & 4.34 & 2.35 & 2.5 & 1.1 & 4.3 & 2.08 \\
\hline 87 & 0 & 0.74 & 0.01 & 0.52 & 0.03 & 0.9 & 0.32 & 0.83 & 0.11 & 0.46 & 0.24 & 0.8 \\
\hline 88 & 0.69 & 0.95 & 0.7 & 1.02 & 0.94 & 1.19 & 1.99 & 1.13 & 2.22 & 0.79 & 2.45 & 1.46 \\
\hline 89 & 0.46 & 1.03 & 0.21 & 0.73 & 0.55 & 1.2 & 1.22 & 1.16 & 0.2 & 0.5 & 0.76 & 1.11 \\
\hline 90 & 0.56 & 0.9 & 0.35 & 0.76 & 0.78 & 1.16 & 1.17 & 1.1 & 0.3 & 0.5 & 1.19 & 1.15 \\
\hline 91 & 2.93 & 2.08 & 0.64 & 1.2 & 1.22 & 1.38 & 5.98 & 3.5 & 1.19 & 1.06 & 3.58 & 1.9 \\
\hline 92 & 1.02 & 1.06 & 1.34 & 0.9 & 0.98 & 1.15 & 0.75 & 1.01 & 0.52 & 0.76 & 0.58 & 1.07 \\
\hline 93 & 0.7 & 1.12 & 0.23 & 0.8 & 0.69 & 1.31 & 1.06 & 1.26 & 0.13 & 0.6 & 0.81 & 1.13 \\
\hline 94 & 0.07 & 0.64 & 0.68 & 1.26 & 0.12 & 0.83 & 0.15 & 1.16 & 0.48 & 0.75 & 0.25 & 1.19 \\
\hline 95 & 0.07 & 0.64 & 0.68 & 1.26 & 0.12 & 0.83 & 0 & 0 & 0 & 0 & 0 & 0 \\
\hline 96 & 0.11 & 0.47 & 7.69 & 6.07 & 0.06 & 0.45 & 0.57 & 0.96 & 31.48 & 28.96 & 0.42 & 0.86 \\
\hline 97 & 0.36 & 0.21 & 5.36 & 4.07 & 0.25 & 0.19 & 0.23 & 0.63 & 5.49 & 5.13 & 0.13 & 0.53 \\
\hline 98 & 0.96 & 0.94 & 0.72 & 0.4 & 0.63 & 0.74 & 0.24 & 0.7 & 0.2 & 0.29 & 0.18 & 0.68 \\
\hline 99 & 0.12 & 1.18 & 0.09 & 0.59 & 0.07 & 0.94 & 0.04 & 0.76 & 0.03 & 0.33 & 0.03 & 0.73 \\
\hline 100 & 0.01 & 1.21 & 0.01 & 0.61 & 0 & 0.98 & 0.07 & 0.78 & 0.05 & 0.33 & 0.05 & 0.75 \\
\hline 101 & 0.09 & 0.24 & 2.14 & 1.79 & 0.06 & 0.26 & 0.02 & 0.66 & 0.68 & 0.93 & 0.01 & 0.62 \\
\hline 102 & 0.06 & 0.39 & 0.77 & 0.87 & 0.04 & 0.41 & 0.05 & 0.97 & 0.76 & 1.08 & 0.04 & 0.94 \\
\hline 103 & 0 & 1.29 & 0 & 0.63 & 0 & 1.04 & 0.01 & 0.78 & 0 & 0.34 & 0 & 0.76 \\
\hline 104 & 0 & 0 & 0 & 0 & 0 & 0 & 0 & 0 & 0 & 0 & 0 & 0 \\
\hline 105 & 0.01 & 0.3 & 0 & 0.24 & 0 & 0.33 & 0 & 0 & 0 & 0 & 0 & 0 \\
\hline 106 & 0 & 0 & 0 & 0 & 0 & 0 & 0 & 0 & 0 & 0 & 0 & 0 \\
\hline 107 & 0.02 & 0.22 & 0.01 & 0.17 & 0.01 & 0.23 & 0.02 & 0.67 & 0.02 & 0.28 & 0.01 & 0.64 \\
\hline 108 & 0.2 & 1.03 & 0.14 & 1.17 & 0.1 & 0.76 & 0.46 & 0.85 & 0.3 & 1.31 & 0.27 & 0.69 \\
\hline 109 & 0.62 & 1.18 & 0.22 & 1.21 & 0.27 & 0.79 & 1.75 & 1.21 & 0.65 & 1.33 & 0.88 & 0.73 \\
\hline 110 & 0.94 & 0.71 & 4.83 & 0.5 & 0.66 & 0.81 & 1.07 & 1.68 & 6.33 & 0.48 & 0.52 & 1.25 \\
\hline 111 & 0.01 & 0.31 & 4.01 & 3.3 & 0.01 & 0.35 & 0.04 & 1.08 & 4.45 & 4.46 & 0.02 & 0.88 \\
\hline 112 & 0.51 & 1.58 & 0.42 & 1.02 & 0.41 & 1.54 & 0.39 & 0.64 & 0.29 & 0.55 & 0.28 & 0.54 \\
\hline 113 & 15.01 & 7.03 & 2.91 & 2.37 & 9.13 & 3.66 & 11.03 & 5.7 & 1.6 & 0.85 & 7.23 & 2.98 \\
\hline 114 & 0.01 & 0.08 & 0.06 & 0.1 & 0.01 & 0.1 & 0.02 & 0.1 & 0 & 0.07 & 0.03 & 0.1 \\
\hline 115 & 2 & 1.41 & 0.64 & 0.78 & 2.22 & 1.3 & 2.07 & 1.58 & 0.75 & 0.47 & 3.02 & 1.38 \\
\hline 116 & 0.19 & 1.27 & 0.34 & 0.78 & 0.17 & 1.52 & 0.13 & 1.97 & 0.13 & 0.37 & 0.15 & 1.21 \\
\hline 117 & 7.69 & 3.21 & 6.61 & 2.68 & 7.51 & 2.66 & 6.02 & 2.85 & 2.96 & 1.24 & 5.92 & 2.16 \\
\hline 118 & 5.26 & 2.47 & 3.37 & 1.32 & 9.03 & 3.35 & 5.69 & 3.21 & 2.42 & 1.11 & 10.26 & 3.97 \\
\hline 119 & 4.8 & 2.67 & 1.32 & 0.96 & 5.09 & 2.21 & 3.39 & 2.52 & 0.37 & 0.47 & 5 & 2.34 \\
\hline 120 & 1.19 & 0.99 & 0.62 & 0.95 & 0.93 & 0.88 & 0.75 & 0.89 & 1.05 & 0.84 & 0.84 & 0.91 \\
\hline 121 & 2.2 & 1.21 & 2.45 & 1.99 & 3.04 & 1.35 & 1.6 & 0.98 & 2.93 & 1.11 & 3.22 & 1.47 \\
\hline 122 & 0.08 & 1.53 & 0.23 & 1.12 & 0.09 & 1.67 & 0.02 & 1.51 & 0.07 & 0.71 & 0.06 & 1.55 \\
\hline 123 & 0.1 & 1.06 & 3.41 & 3.46 & 0.13 & 1.37 & 0.17 & 0.62 & 12.51 & 11.76 & 0.17 & 0.7 \\
\hline 124 & 0.02 & 1.29 & 0.33 & 1.43 & 0.01 & 2.11 & 0.06 & 0.65 & 0.14 & 0.92 & 0.02 & 0.77 \\
\hline 125 & 0.51 & 0.93 & 7.35 & 6.31 & 0.52 & 1 & 0.93 & 0.88 & 4.62 & 4.59 & 0.54 & 0.69 \\
\hline 126 & 2.29 & 0.94 & 4.87 & 1.98 & 3.58 & 1.45 & 2.84 & 1.12 & 9.46 & 1.75 & 4.1 & 1.42 \\
\hline 127 & 3.45 & 1.54 & 3.13 & 1.84 & 4.16 & 1.55 & 3.67 & 2.01 & 1.58 & 0.89 & 3.19 & 1.22 \\
\hline 128 & 4.77 & 1.62 & 2.7 & 0.7 & 5.54 & 1.7 & 5.14 & 1.92 & 1.76 & 0.38 & 4.61 & 1.72 \\
\hline 129 & 2.52 & 1.85 & 0.92 & 0.73 & 1.38 & 1.55 & 3.42 & 2.49 & 0.97 & 0.6 & 1.57 & 2.25 \\
\hline 130 & 1.76 & 1.04 & 1.39 & 0.75 & 2.21 & 1.61 & 1.32 & 0.71 & 0.47 & 0.21 & 1.74 & 0.94 \\
\hline 131 & 17.34 & 7.24 & 2.4 & 0.46 & 4.21 & 0.75 & 16.51 & 6.71 & 2.82 & 0.21 & 6.02 & 0.89 \\
\hline 132 & 1.31 & 0.8 & 1.65 & 0.8 & 1.51 & 1.1 & 1.97 & 0.3 & 3 & 0.25 & 2.07 & 0.35 \\
\hline 133 & 3.65 & 1.61 & 1.8 & 0.68 & 3.87 & 1.41 & 1.9 & 0.89 & 0.69 & 0.21 & 2.45 & 0.92 \\
\hline 134 & 1.38 & 1.31 & 1.43 & 0.88 & 1.66 & 1.47 & 0.6 & 1.3 & 0.23 & 0.45 & 0.56 & 1.26 \\
\hline 135 & 14.25 & 2.1 & 12.89 & 1.94 & 24.92 & 5.29 & 11.09 & 1.51 & 8.84 & 1.14 & 21.65 & 5.28 \\
\hline 136 & 10.56 & 5.29 & 1.51 & 0.83 & 9.67 & 3.74 & 9.95 & 5.32 & 2.53 & 0.89 & 7.61 & 3.09 \\
\hline 137 & 6.43 & 3.09 & 0.87 & 0.43 & 8.05 & 2.92 & 6.77 & 3.48 & 0.75 & 0.57 & 7.21 & 2.69 \\
\hline 138 & 11.65 & 5.75 & 0.58 & 0.53 & 12.82 & 4.73 & 12.32 & 6.71 & 0.51 & 0.65 & 11.21 & 4.5 \\
\hline 139 & 0.08 & 0.77 & 0.24 & 0.38 & 0.08 & 0.67 & 0.13 & 0.92 & 0.06 & 0.44 & 0.1 & 1.26 \\
\hline 140 & 0.08 & 0.77 & 0.24 & 0.38 & 0.08 & 0.68 & 0.18 & 0.92 & 0.09 & 0.44 & 0.14 & 1.26 \\
\hline 141 & 0.03 & 0.76 & 0.18 & 0.37 & 0.04 & 0.67 & 0.18 & 0.9 & 0.08 & 0.43 & 0.14 & 1.26 \\
\hline 142 & 0.1 & 0.78 & 0.28 & 0.39 & 0.1 & 0.68 & 0.22 & 0.95 & 0.11 & 0.45 & 0.17 & 1.27 \\
\hline 143 & 0.02 & 0.76 & 0.16 & 0.38 & 0.02 & 0.67 & 0.03 & 0.88 & 0.01 & 0.44 & 0.02 & 1.25 \\
\hline
\end{tabular}


Table A1. Cont.

\begin{tabular}{|c|c|c|c|c|c|c|c|c|c|c|c|c|}
\hline 144 & 0.02 & 0.76 & 0.17 & 0.38 & 0.02 & 0.67 & 0.11 & 0.9 & 0.05 & 0.44 & 0.09 & 1.25 \\
\hline 145 & 0.09 & 0.77 & 0.26 & 0.38 & 0.1 & 0.68 & 0.18 & 0.92 & 0.08 & 0.44 & 0.13 & 1.26 \\
\hline 146 & 0.01 & 0.76 & 0.15 & 0.36 & 0.01 & 0.67 & 0.03 & 0.88 & 0.02 & 0.43 & 0.03 & 1.25 \\
\hline 147 & 0 & 0.76 & 0.14 & 0.36 & 0 & 0.67 & 0 & 0.88 & 0 & 0.43 & 0 & 1.25 \\
\hline 148 & 0.08 & 0.77 & 0.24 & 0.37 & 0.08 & 0.68 & 0.18 & 0.92 & 0.08 & 0.43 & 0.14 & 1.27 \\
\hline 149 & 0.05 & 0.77 & 0.2 & 0.41 & 0.05 & 0.67 & 0.1 & 0.91 & 0.05 & 0.46 & 0.07 & 1.25 \\
\hline 150 & 0 & 0.76 & 0.14 & 0.37 & 0 & 0.67 & 0 & 0.87 & 0 & 0.43 & 0 & 1.25 \\
\hline 151 & 0.03 & 0.76 & 0.21 & 0.43 & 0.03 & 0.67 & 0.04 & 0.91 & 0.05 & 0.48 & 0.03 & 1.25 \\
\hline 152 & 0.05 & 0.77 & 0.24 & 0.43 & 0.05 & 0.67 & 0.09 & 0.92 & 0.07 & 0.48 & 0.07 & 1.25 \\
\hline 153 & 0.05 & 0.77 & 0.2 & 0.38 & 0.05 & 0.67 & 0 & 0.9 & 0 & 0.44 & 0 & 1.25 \\
\hline 154 & 0.03 & 0.77 & 0.18 & 0.38 & 0.03 & 0.67 & 0 & 0.9 & 0 & 0.44 & 0 & 1.25 \\
\hline 155 & 0.01 & 0.76 & 0.15 & 0.37 & 0.01 & 0.67 & 0 & 0.9 & 0 & 0.43 & 0 & 1.25 \\
\hline 156 & 0.14 & 0.78 & 0.32 & 0.39 & 0.14 & 0.68 & 0.04 & 0.91 & 0.02 & 0.44 & 0.03 & 1.25 \\
\hline 157 & 0.01 & 0.76 & 0.14 & 0.37 & 0.01 & 0.67 & 0 & 0.89 & 0 & 0.43 & 0 & 1.25 \\
\hline 158 & 0.02 & 0.76 & 0.16 & 0.37 & 0.02 & 0.67 & 0 & 0.89 & 0 & 0.43 & 0 & 1.25 \\
\hline 159 & 0.52 & 1.24 & 0.42 & 0.8 & 0.7 & 1.24 & 1.17 & 0.94 & 0.44 & 0.29 & 1.74 & 0.91 \\
\hline 160 & 4.14 & 2.62 & 1.47 & 1.32 & 3.56 & 1.94 & 3.46 & 1.94 & 0.93 & 0.63 & 3.67 & 1.46 \\
\hline 161 & 0.87 & 0.9 & 0.33 & 0.54 & 0.96 & 0.89 & 1.99 & 1 & 0.58 & 0.32 & 2.64 & 0.95 \\
\hline 162 & 0.59 & 0.25 & 0.28 & 0.21 & 1.92 & 0.66 & 0.4 & 0.2 & 0.02 & 0.01 & 1.84 & 0.67 \\
\hline 163 & 0 & 0 & 0.13 & 0.1 & 0 & 0 & 0 & 0 & 0 & 0 & 0 & 0 \\
\hline & \multicolumn{6}{|c|}{ Sweden } & \multicolumn{6}{|c|}{ USA } \\
\hline & \multicolumn{2}{|c|}{ Final Demand } & \multicolumn{2}{|c|}{$\mathrm{CO}_{2}$} & \multicolumn{2}{|c|}{ Employment } & \multicolumn{2}{|c|}{ Final Demand } & \multicolumn{2}{|c|}{$\mathrm{CO}_{2}$} & \multicolumn{2}{|c|}{ Employment } \\
\hline Sector ID & Fwd & Bckwd & Fwd & Bckwd & Fwd & Bckwd & Fwd & Bckwd & Fwd & Bckwd & Fwd & Bckwd \\
\hline 1 & 0 & 0 & 0 & 0 & 0 & 0 & 0.02 & 1.61 & 0.02 & 0.64 & 0.04 & 0.67 \\
\hline 2 & 0.14 & 0.78 & 0.33 & 0.76 & 0.22 & 0.76 & 0.05 & 1.87 & 0.09 & 0.7 & 0.06 & 0.77 \\
\hline 3 & 0.2 & 0.71 & 0.39 & 0.73 & 0.46 & 0.76 & 0.17 & 1.59 & 0.44 & 0.81 & 0.17 & 0.71 \\
\hline 4 & 0.08 & 0.51 & 0.17 & 0.37 & 0.1 & 0.49 & 0.4 & 0.99 & 0.15 & 0.61 & 0.47 & 0.66 \\
\hline 5 & 0.04 & 0.2 & 0.09 & 0.18 & 0.11 & 0.22 & 0.07 & 1.53 & 0.13 & 0.64 & 0.09 & 0.65 \\
\hline 6 & 0.02 & 0.73 & 0.04 & 0.4 & 0.02 & 0.71 & 0.02 & 1.43 & 0.02 & 0.74 & 0.02 & 0.73 \\
\hline 7 & 0 & 0 & 0 & 0 & 0 & 0 & 0.02 & 1.47 & 0.04 & 0.78 & 0.04 & 0.76 \\
\hline 8 & 0.09 & 1.08 & 0.13 & 0.6 & 0.27 & 1.05 & 0.3 & 1.21 & 0.3 & 0.78 & 0.71 & 0.9 \\
\hline 9 & 0.08 & 1.82 & 0.13 & 1.25 & 0.18 & 1.91 & 0.37 & 1.45 & 0.19 & 0.82 & 0.27 & 0.89 \\
\hline 10 & 0.22 & 0.77 & 0.08 & 0.49 & 0.24 & 0.83 & 0.1 & 0.88 & 0.05 & 0.5 & 0.14 & 0.55 \\
\hline 11 & 0.12 & 0.63 & 0.02 & 0.42 & 0.11 & 0.64 & 0.19 & 1.39 & 0.07 & 1.06 & 0.15 & 1.16 \\
\hline 12 & 0.07 & 0.26 & 0.04 & 0.16 & 0.08 & 0.28 & 0 & 0.77 & 0 & 0.44 & 0 & 0.58 \\
\hline 13 & 0.06 & 0.28 & 0.03 & 0.17 & 0.07 & 0.3 & 0.05 & 0.87 & 0 & 0.64 & 0.02 & 0.75 \\
\hline 14 & 0.39 & 0.6 & 0.19 & 0.37 & 0.45 & 0.73 & 0.18 & 1.08 & 0.06 & 0.76 & 0.22 & 0.78 \\
\hline 15 & 0 & 0.69 & 0 & 0.4 & 0 & 0.71 & 0 & 0.87 & 0 & 0.54 & 0 & 0.68 \\
\hline 16 & 0 & 0 & 0.01 & 0.01 & 0 & 0 & 0 & 0 & 0.04 & 0.02 & 0 & 0 \\
\hline 17 & 0 & 0 & 0 & 0 & 0 & 0 & 0 & 0 & 0 & 0 & 0 & 0 \\
\hline 18 & 0.71 & 0.32 & 0.84 & 0.49 & 1.28 & 0.52 & 0.26 & 0.74 & 0.53 & 0.65 & 0.57 & 0.75 \\
\hline 19 & 0.05 & 0.47 & 0.07 & 0.5 & 0.06 & 0.5 & 0.01 & 0.68 & 0.02 & 0.46 & 0.03 & 0.68 \\
\hline 20 & 0.03 & 0.61 & 0.42 & 0.58 & 0.04 & 0.71 & 0.17 & 0.56 & 8.1 & 0.74 & 0.2 & 0.84 \\
\hline 21 & 0 & 0 & 0 & 0 & 0 & 0 & 0.47 & 0.81 & 1.42 & 0.87 & 0.32 & 1.01 \\
\hline 22 & 0 & 0 & 0 & 0 & 0 & 0 & 0.63 & 0.73 & 4.95 & 1.44 & 0.5 & 0.94 \\
\hline 23 & 0 & 0 & 0 & 0 & 0 & 0 & 0.06 & 0.79 & 0.01 & 1.35 & 0 & 0.81 \\
\hline 24 & 0 & 0 & 0 & 0 & 0 & 0 & 0 & 0.38 & 0 & 0.94 & 0.01 & 0.61 \\
\hline 25 & 0 & 0.46 & 0.65 & 0.87 & 0.01 & 0.48 & 0.04 & 0.79 & 0.26 & 1.25 & 0.04 & 1.31 \\
\hline 26 & 0.13 & 0.37 & 0.31 & 0.36 & 0.16 & 0.43 & 0.02 & 0.48 & 0.04 & 1.03 & 0.02 & 0.62 \\
\hline 27 & 0 & 0 & 0 & 0 & 0 & 0 & 0 & 0 & 0 & 0 & 0 & 0 \\
\hline 28 & 0 & 0 & 0 & 0 & 0 & 0 & 0 & 0.46 & 0 & 0.91 & 0 & 0.7 \\
\hline 29 & 0 & 0.47 & 0.41 & 0.71 & 0 & 0.49 & 0.01 & 0.51 & 0.02 & 0.99 & 0.02 & 0.71 \\
\hline 30 & 0.01 & 0.51 & 0.14 & 0.49 & 0.03 & 0.53 & 0 & 0.66 & 0 & 1.37 & 0 & 0.69 \\
\hline 31 & 0 & 0.4 & 0 & 0.36 & 0 & 0.39 & 0 & 0.57 & 0 & 0.95 & 0 & 0.75 \\
\hline 32 & 0.15 & 0.62 & 0.11 & 0.54 & 0.14 & 0.72 & 0.09 & 0.55 & 0.25 & 0.81 & 0.1 & 0.82 \\
\hline 33 & 0.12 & 0.48 & 0.15 & 0.46 & 0.12 & 0.52 & 0.06 & 0.57 & 0.13 & 0.91 & 0.07 & 0.87 \\
\hline 34 & 0.02 & 0.8 & 0.05 & 0.6 & 0.01 & 0.77 & 0.02 & 0.62 & 0.14 & 1.05 & 0.03 & 0.86 \\
\hline 35 & 0.51 & 0.86 & 0.09 & 0.53 & 0.2 & 0.85 & 0.3 & 1.49 & 0.07 & 0.87 & 0.11 & 0.99 \\
\hline 36 & 0.53 & 0.92 & 0.19 & 0.59 & 0.23 & 0.9 & 0.24 & 1.08 & 0.11 & 0.88 & 0.16 & 1.13 \\
\hline
\end{tabular}


Table A1. Cont.

\begin{tabular}{|c|c|c|c|c|c|c|c|c|c|c|c|c|}
\hline 37 & 0.14 & 1.14 & 0.05 & 1.03 & 0.04 & 2.34 & 0.33 & 1.21 & 0.13 & 1.15 & 0.23 & 1.42 \\
\hline 38 & 0.37 & 0.74 & 0.03 & 0.36 & 0.08 & 0.67 & 0.15 & 1 & 0.04 & 1.08 & 0.24 & 1.38 \\
\hline 39 & 0.01 & 0.06 & 0 & 0.05 & 0.02 & 0.09 & 0.15 & 1.4 & 0.09 & 0.89 & 0.11 & 1.04 \\
\hline 40 & 0.91 & 1.36 & 0.42 & 0.89 & 0.28 & 1.09 & 0.56 & 1.18 & 0.12 & 0.97 & 0.4 & 1.16 \\
\hline 41 & 0 & 0.9 & 0 & 1.14 & 0 & 1.3 & 0 & 1.31 & 0 & 1.36 & 0 & 1.83 \\
\hline 42 & 0.04 & 0.46 & 0.02 & 0.28 & 0.01 & 0.48 & 0.06 & 1.13 & 0.04 & 0.99 & 0.04 & 1.15 \\
\hline 43 & 1.1 & 1.1 & 0.5 & 0.93 & 1.13 & 1.08 & 2.03 & 1.63 & 1.18 & 1.51 & 1.24 & 1.41 \\
\hline 44 & 0.44 & 1.27 & 0.12 & 0.81 & 0.23 & 1.24 & 0.57 & 1.19 & 0.08 & 1.06 & 0.15 & 1.27 \\
\hline 45 & 0.04 & 1.16 & 0.01 & 0.73 & 0.02 & 1.18 & 0.07 & 0.72 & 0.02 & 0.71 & 0.09 & 0.97 \\
\hline 46 & 0 & 0 & 0 & 0 & 0 & 0 & 0.36 & 0.48 & 0.02 & 0.35 & 0.02 & 0.44 \\
\hline 47 & 0.06 & 0.65 & 0.11 & 0.56 & 0.21 & 0.78 & 0.67 & 1.04 & 0.35 & 1.1 & 0.54 & 1.17 \\
\hline 48 & 0.01 & 0.82 & 0.01 & 0.62 & 0.06 & 0.9 & 0.24 & 0.95 & 0.03 & 0.9 & 0.14 & 1.37 \\
\hline 49 & 0 & 0.74 & 0.01 & 0.47 & 0.03 & 0.84 & 0.04 & 0.83 & 0.01 & 0.82 & 0.03 & 1.13 \\
\hline 50 & 1.94 & 0.85 & 1.58 & 0.93 & 2.26 & 1.21 & 0.76 & 0.84 & 0.53 & 0.88 & 0.93 & 1.07 \\
\hline 51 & 0.01 & 0.76 & 0 & 0.79 & 0.01 & 0.86 & 0 & 0.75 & 0.03 & 0.79 & 0 & 0.97 \\
\hline 52 & 0.1 & 0.77 & 0.5 & 1.16 & 0.22 & 0.89 & 0.01 & 0.85 & 0.06 & 0.97 & 0.02 & 0.98 \\
\hline 53 & 0.01 & 0.89 & 0.82 & 1.65 & 0.03 & 0.96 & 0 & 0.74 & 0.11 & 0.92 & 0.01 & 0.94 \\
\hline 54 & 0.81 & 0.85 & 0.93 & 0.94 & 1.38 & 1.11 & 1.19 & 0.84 & 1.14 & 1.07 & 1.24 & 1.02 \\
\hline 55 & 2.14 & 1.41 & 2.43 & 1.91 & 2.82 & 1.55 & 2.06 & 0.99 & 1.82 & 1.16 & 2.64 & 1.29 \\
\hline 56 & 0.03 & 0.4 & 2.16 & 2.33 & 0.03 & 0.57 & 0 & 1.12 & 0.1 & 1.12 & 0 & 1.18 \\
\hline 57 & 1.06 & 0.31 & 4.94 & 2.81 & 0.56 & 0.03 & 1.81 & 0.97 & 5.23 & 2.84 & 0.86 & 0.76 \\
\hline 58 & 0 & 0.67 & 0.02 & 0.51 & 0.08 & 0.72 & 0 & 1.03 & 0 & 1.16 & 0 & 0.68 \\
\hline 59 & 0.97 & 0.73 & 1.62 & 1.32 & 1.42 & 1.03 & 0.31 & 0.99 & 0.37 & 1.51 & 0.31 & 1.3 \\
\hline 60 & 0 & 0.77 & 0.03 & 0.52 & 0.01 & 0.98 & 0.04 & 0.97 & 0.03 & 1.39 & 0.04 & 1.31 \\
\hline 61 & 0 & 0.25 & 7.9 & 6.73 & 0 & 0.23 & 0 & 0.99 & 1.32 & 1.99 & 0 & 1.29 \\
\hline 62 & 0 & 0.5 & 0.02 & 0.39 & 0 & 0.66 & 0.06 & 1.01 & 0.64 & 1.44 & 0.09 & 1.27 \\
\hline 63 & 0.01 & 0.85 & 0.09 & 0.63 & 0.01 & 0.93 & 2.84 & 1.21 & 3.17 & 2.05 & 2.07 & 1.31 \\
\hline 64 & 0.54 & 0.73 & 0.51 & 0.74 & 0.94 & 1.02 & 1.33 & 0.85 & 1.15 & 1.19 & 1.47 & 1.15 \\
\hline 65 & 0.05 & 0.71 & 0.45 & 0.94 & 0.06 & 0.76 & 0.16 & 0.69 & 0.51 & 1.1 & 0.18 & 0.92 \\
\hline 66 & 0.03 & 0.7 & 0.19 & 0.71 & 0.03 & 0.75 & 0.01 & 0.58 & 0.21 & 0.87 & 0.01 & 0.87 \\
\hline 67 & 0.09 & 0.74 & 0.12 & 0.74 & 0.09 & 0.76 & 0.03 & 0.61 & 0.03 & 0.8 & 0.03 & 0.92 \\
\hline 68 & 0.01 & 0.67 & 0.07 & 0.72 & 0.01 & 0.7 & 0.04 & 0.61 & 0.23 & 0.89 & 0.05 & 0.85 \\
\hline 69 & 0.77 & 0.84 & 6 & 5.54 & 0.79 & 1 & 0.43 & 0.73 & 1.79 & 1.73 & 0.51 & 1.03 \\
\hline 70 & 0 & 0.81 & 0.4 & 1.75 & 0 & 0.87 & 0.01 & 0.71 & 0.16 & 0.94 & 0.01 & 0.98 \\
\hline 71 & 0.06 & 0.66 & 0.26 & 0.8 & 0.07 & 0.69 & 0.11 & 0.66 & 0.29 & 0.89 & 0.13 & 0.91 \\
\hline 72 & 0.23 & 0.59 & 14.69 & 12.41 & 0.69 & 0.83 & 0.44 & 0.94 & 2.42 & 2.17 & 0.58 & 1.17 \\
\hline 73 & 0.08 & 0.56 & 4.55 & 4.47 & 0.25 & 0.68 & 0.01 & 0.84 & 0.13 & 1.51 & 0.01 & 1.07 \\
\hline 74 & 0.02 & 0.66 & 0.07 & 0.44 & 0.02 & 0.7 & 0.04 & 0.71 & 0.03 & 0.83 & 0.04 & 0.93 \\
\hline 75 & 0 & 0 & 0 & 0 & 0 & 0 & 0 & 0.71 & 0 & 0.73 & 0 & 0.94 \\
\hline 76 & 0.16 & 0.57 & 1.55 & 1.57 & 0.18 & 0.66 & 0.16 & 0.82 & 0.51 & 1.34 & 0.17 & 0.92 \\
\hline 77 & 0.01 & 0.59 & 0.05 & 0.59 & 0.01 & 0.69 & 0.04 & 0.83 & 0.07 & 0.79 & 0.05 & 0.94 \\
\hline 78 & 0.04 & 0.62 & 0.34 & 0.69 & 0.05 & 0.71 & 0 & 0.39 & 0.01 & 0.53 & 0 & 0.51 \\
\hline 79 & 0 & 0.59 & 0.03 & 0.51 & 0 & 0.68 & 0 & 0.34 & 0 & 0.41 & 0 & 0.47 \\
\hline 80 & 0.48 & 0.8 & 0.81 & 0.81 & 0.49 & 0.87 & 0.08 & 0.75 & 0.06 & 0.72 & 0.09 & 0.88 \\
\hline 81 & 0.02 & 0.75 & 0.08 & 0.69 & 0.02 & 0.82 & 0 & 0.75 & 0 & 0.79 & 0.01 & 0.88 \\
\hline 82 & 0.01 & 0.65 & 0.01 & 0.43 & 0.01 & 0.66 & 0.01 & 0.9 & 0.01 & 1.17 & 0.01 & 0.95 \\
\hline 83 & 0 & 1.75 & 0 & 1.06 & 0 & 1.83 & 0.01 & 0.9 & 0.01 & 0.85 & 0.01 & 0.96 \\
\hline 84 & 0.15 & 0.71 & 1.22 & 1.54 & 0.17 & 0.78 & 0.2 & 0.73 & 0.29 & 0.98 & 0.21 & 1 \\
\hline 85 & 2.45 & 1.13 & 1.89 & 1.07 & 3.53 & 1.65 & 1.88 & 0.8 & 1.56 & 0.98 & 2.36 & 1.26 \\
\hline 86 & 3.27 & 1.94 & 1.7 & 1.13 & 3.55 & 2.05 & 2.34 & 1.28 & 1.62 & 0.89 & 1.71 & 1.16 \\
\hline 87 & -0.01 & 0.65 & 0.02 & 0.47 & 0.09 & 0.78 & 0.51 & 0.92 & 0.07 & 0.67 & 0.14 & 1.08 \\
\hline 88 & 1.32 & 1.11 & 0.64 & 0.67 & 1.28 & 1.28 & 0.6 & 0.68 & 0.41 & 0.78 & 0.62 & 0.96 \\
\hline 89 & 0.55 & 0.88 & 0.29 & 0.53 & 0.94 & 1.3 & 1.38 & 0.9 & 0.53 & 0.72 & 1.12 & 1.15 \\
\hline 90 & 0.89 & 0.93 & 0.23 & 0.51 & 0.93 & 0.99 & 1.13 & 1.01 & 0.2 & 0.75 & 0.67 & 1.15 \\
\hline 91 & 3.96 & 2.39 & 1.26 & 1.14 & 2.94 & 1.82 & 3.61 & 1.9 & 0.95 & 0.94 & 1.53 & 1.16 \\
\hline 92 & 0.71 & 0.76 & 0.99 & 0.57 & 0.92 & 0.93 & 1 & 0.91 & 0.37 & 0.78 & 0.7 & 1.18 \\
\hline 93 & 0.77 & 0.98 & 0.4 & 0.84 & 1.22 & 1.25 & 1.21 & 1.12 & 0.33 & 0.82 & 1.11 & 1.2 \\
\hline 94 & 0.08 & 0.75 & 1.48 & 1.46 & 0.17 & 0.85 & 0 & 0.63 & 0 & 0.76 & 0 & 0.87 \\
\hline 95 & 0 & 0 & 0.01 & 0.01 & 0 & 0 & 0 & 0 & 0 & 0 & 0 & 0 \\
\hline 96 & 0.06 & 0.62 & 1.03 & 1.28 & 0.02 & 0.64 & 0.55 & 0.72 & 35.63 & 20.92 & 0.47 & 0.82 \\
\hline
\end{tabular}


Table A1. Cont.

\begin{tabular}{|c|c|c|c|c|c|c|c|c|c|c|c|c|}
\hline 97 & 0.03 & 0.56 & 2.54 & 2.46 & 0.01 & 0.55 & 0.23 & 0.67 & 7.06 & 4.81 & 0.17 & 0.79 \\
\hline 98 & 0.55 & 0.59 & 1.21 & 0.23 & 0.41 & 0.55 & 0.19 & 0.31 & 0.13 & 0.21 & 0.17 & 0.37 \\
\hline 99 & 0.53 & 0.73 & 1.24 & 0.28 & 0.36 & 0.63 & 0.05 & 0.39 & 0.04 & 0.25 & 0.05 & 0.42 \\
\hline 100 & 0.01 & 0.61 & 0.02 & 0.29 & 0.01 & 0.6 & 0.01 & 0.4 & 0.01 & 0.26 & 0.01 & 0.43 \\
\hline 101 & 0.03 & 0.54 & 0.87 & 1.22 & 0.01 & 0.52 & 0.02 & 0.61 & 1.06 & 1.34 & 0.02 & 0.72 \\
\hline 102 & 0.45 & 0.75 & 1.04 & 1.06 & 0.19 & 0.63 & 0.01 & 0.55 & 0.3 & 0.56 & 0.01 & 0.69 \\
\hline 103 & 0 & 0.53 & 0 & 0.26 & 0 & 0.58 & 0 & 0.49 & 0 & 0.29 & 0 & 0.54 \\
\hline 104 & 0 & 0 & 0 & 0 & 0 & 0 & 0 & 0.45 & 0 & 0.27 & 0 & 0.5 \\
\hline 105 & 0 & 0 & 0 & 0 & 0 & 0 & 0 & 0 & 0 & 0 & 0 & 0 \\
\hline 106 & 0 & 0 & 0 & 0 & 0 & 0 & 0 & 0.46 & 0 & 0.27 & 0 & 0.51 \\
\hline 107 & 0.02 & 0.57 & 0.01 & 0.36 & 0.01 & 0.55 & 0 & 0.48 & 0 & 0.36 & 0 & 0.54 \\
\hline 108 & 0.35 & 0.68 & 0.92 & 0.37 & 0.22 & 0.6 & 0.14 & 0.46 & 0.1 & 0.29 & 0.11 & 0.49 \\
\hline 109 & 1.1 & 0.96 & 1.04 & 0.37 & 0.59 & 0.7 & 0.64 & 0.58 & 0.31 & 0.3 & 0.46 & 0.51 \\
\hline 110 & 0.03 & 0.7 & 0.23 & 0.49 & 0.02 & 0.69 & 0.69 & 0.73 & 0.93 & 0.92 & 0.48 & 0.75 \\
\hline 111 & 0.44 & 0.78 & 10.25 & 8.84 & 0.18 & 0.65 & 0 & 0.66 & 0.69 & 0.91 & 0 & 0.67 \\
\hline 112 & 0.48 & 0.94 & 0.19 & 0.48 & 0.39 & 0.9 & 0.03 & 0.93 & 0.01 & 0.46 & 0.01 & 0.82 \\
\hline 113 & 13.69 & 5.69 & 2.49 & 1.32 & 8.7 & 3.79 & 9.62 & 4.25 & 2.91 & 1.34 & 7.13 & 2.87 \\
\hline 114 & 0.01 & 0.1 & 0 & 0.09 & 0.01 & 0.15 & 0 & 0.1 & 0 & 0.17 & 0 & 0.13 \\
\hline 115 & 1.54 & 1.32 & 0.85 & 0.69 & 2.2 & 1.37 & 3.48 & 1.75 & 0.68 & 0.5 & 4.29 & 1.72 \\
\hline 116 & 0.23 & 1.76 & 0.3 & 0.72 & 0.21 & 1.33 & 0.12 & 0.99 & 0.11 & 0.9 & 0.1 & 1.44 \\
\hline 117 & 6.55 & 2.93 & 3.96 & 1.55 & 8.49 & 3.45 & 6.42 & 2.24 & 5.61 & 1.04 & 8.93 & 2.87 \\
\hline 118 & 4.28 & 2.61 & 2.01 & 1.08 & 5.97 & 2.78 & 4.58 & 2.12 & 5.21 & 1.38 & 6.07 & 2.17 \\
\hline 119 & 3.61 & 2.85 & 0.85 & 0.55 & 4.18 & 2.19 & 5.24 & 2.59 & 1.85 & 0.92 & 8.86 & 3.25 \\
\hline 120 & 0.87 & 0.8 & 0.77 & 0.58 & 0.68 & 0.67 & 0.35 & 0.83 & 0.98 & 0.95 & 0.3 & 0.83 \\
\hline 121 & 3.36 & 1.15 & 5.34 & 2.03 & 5.26 & 1.9 & 2.03 & 1.23 & 2.68 & 1.57 & 2.22 & 1.3 \\
\hline 122 & 0.1 & 1.27 & 0.37 & 0.99 & 0.14 & 1.33 & 0.2 & 1.13 & 1.03 & 1.53 & 0.13 & 1.39 \\
\hline 123 & 0.28 & 0.86 & 8.92 & 7.92 & 0.53 & 0.99 & 0.02 & 1.23 & 0.49 & 1.03 & 0.05 & 0.98 \\
\hline 124 & 0.04 & 0.91 & 0.72 & 1.56 & 0.03 & 0.97 & 0.03 & 0.93 & 0.2 & 1.01 & 0.01 & 1.28 \\
\hline 125 & 0.66 & 1.06 & 11.69 & 10.23 & 0.54 & 0.94 & 0.71 & 1.03 & 4.39 & 3.14 & 0.55 & 0.88 \\
\hline 126 & 4.92 & 2.12 & 9.83 & 2.89 & 4.75 & 1.74 & 1.02 & 0.83 & 2 & 0.88 & 2.21 & 1.19 \\
\hline 127 & 3.94 & 2.04 & 2.6 & 1.53 & 3.79 & 1.74 & 4.78 & 1.54 & 4.07 & 1.64 & 4.71 & 1.22 \\
\hline 128 & 3 & 1.6 & 0.99 & 0.42 & 2.44 & 1.33 & 5.4 & 1.66 & 2.38 & 0.49 & 5.07 & 1.4 \\
\hline 129 & 2.11 & 1.63 & 0.59 & 0.3 & 1.01 & 0.91 & 3.91 & 1.48 & 1.03 & 0.4 & 3.25 & 1.11 \\
\hline 130 & 0.31 & 1.4 & 0.3 & 0.47 & 0.54 & 1.12 & 3.71 & 1.17 & 2.01 & 0.3 & 3.2 & 0.9 \\
\hline 131 & 18.29 & 7.52 & 2.9 & 0.89 & 8.04 & 1.7 & 16.42 & 5.9 & 3.19 & 0.54 & 6.75 & 0.83 \\
\hline 132 & 0.84 & 1 & 1.18 & 0.6 & 0.71 & 0.95 & 1.8 & 0.75 & 3.04 & 0.95 & 1.89 & 0.78 \\
\hline 133 & 3.81 & 2.04 & 1.79 & 0.6 & 4.18 & 2 & 3.88 & 1.61 & 1.4 & 0.6 & 2.99 & 1.14 \\
\hline 134 & 0.34 & 1.23 & 0.55 & 0.72 & 1.99 & 1.87 & 0.9 & 0.78 & 0.7 & 0.66 & 1.44 & 1.22 \\
\hline 135 & 9.94 & 1.7 & 8.31 & 1.71 & 16.59 & 4.42 & 13.65 & 1.11 & 14.64 & 2.47 & 24.04 & 4.2 \\
\hline 136 & 10.14 & 5.58 & 1.32 & 0.72 & 7.79 & 3.62 & 18.86 & 8.58 & 4.5 & 2.71 & 9.5 & 3.49 \\
\hline 137 & 9.35 & 5.7 & 0.38 & 0.42 & 10.74 & 5.18 & 1.31 & 1.69 & 0.13 & 0.62 & 8.56 & 3.41 \\
\hline 138 & 17.65 & 9.53 & 0.52 & 0.47 & 17.47 & 8.06 & 10.59 & 5.47 & 0.49 & 0.8 & 10.59 & 4.13 \\
\hline 139 & 0.07 & 0.94 & 0.08 & 0.65 & 0.06 & 1.12 & 0.01 & 0.7 & 0.01 & 0.58 & 0.02 & 0.8 \\
\hline 140 & 0.06 & 0.93 & 0.07 & 0.64 & 0.06 & 1.13 & 0.02 & 0.7 & 0.01 & 0.57 & 0.03 & 0.8 \\
\hline 141 & 0.04 & 0.92 & 0.04 & 0.63 & 0.04 & 1.17 & 0.05 & 0.69 & 0.02 & 0.56 & 0.05 & 0.8 \\
\hline 142 & 0.32 & 0.9 & 0.23 & 0.65 & 0.34 & 1.24 & 0.02 & 0.7 & 0.02 & 0.57 & 0.02 & 0.8 \\
\hline 143 & 0.01 & 0.93 & 0.02 & 0.64 & 0.01 & 1.13 & 0.01 & 0.7 & 0 & 0.57 & 0.01 & 0.8 \\
\hline 144 & 0.06 & 0.93 & 0.06 & 0.64 & 0.05 & 1.14 & 0.01 & 0.7 & 0 & 0.57 & 0.01 & 0.8 \\
\hline 145 & 0.06 & 0.94 & 0.07 & 0.64 & 0.06 & 1.13 & 0 & 0.7 & 0 & 0.57 & 0 & 0.8 \\
\hline 146 & 0 & 0.97 & 0.01 & 0.63 & 0 & 1.21 & 0 & 0 & 0 & 0 & 0 & 0 \\
\hline 147 & 0 & 0.98 & 0.01 & 0.62 & 0 & 1.22 & 0 & 0 & 0 & 0 & 0 & 0 \\
\hline 148 & 0.03 & 0.98 & 0.03 & 0.61 & 0.03 & 1.24 & 0.13 & 0.75 & 0.07 & 0.55 & 0.15 & 0.83 \\
\hline 149 & 0.03 & 0.91 & 0.05 & 0.66 & 0.04 & 1.14 & 0 & 0.7 & 0 & 0.62 & 0 & 0.8 \\
\hline 150 & 0 & 0 & 0.01 & 0.01 & 0 & 0 & 0.04 & 0.7 & 0.02 & 0.56 & 0.05 & 0.8 \\
\hline 151 & 0.01 & 0.91 & 0.06 & 0.68 & 0.01 & 1.13 & 0.03 & 0.69 & 0.03 & 0.57 & 0.03 & 0.89 \\
\hline 152 & 0.02 & 0.91 & 0.07 & 0.69 & 0.02 & 1.13 & 0.01 & 0.68 & 0.02 & 0.63 & 0.01 & 0.99 \\
\hline 153 & 0 & 0.93 & 0.01 & 0.64 & 0 & 1.16 & 0.03 & 0.7 & 0.02 & 0.55 & 0.04 & 0.8 \\
\hline 154 & 0.01 & 0.94 & 0.02 & 0.63 & 0.01 & 1.18 & 0.04 & 0.7 & 0.02 & 0.55 & 0.05 & 0.81 \\
\hline 155 & 0 & 0.94 & 0.01 & 0.63 & 0 & 1.18 & 0.03 & 0.7 & 0.02 & 0.54 & 0.04 & 0.8 \\
\hline 156 & 0.03 & 0.94 & 0.03 & 0.64 & 0.03 & 1.19 & 0.05 & 0.7 & 0.03 & 0.54 & 0.06 & 0.81 \\
\hline
\end{tabular}


Table A1. Cont.

\begin{tabular}{ccccccccccccc}
\hline $\mathbf{1 5 7}$ & 0 & 0.94 & 0.01 & 0.63 & 0 & 1.18 & 0.01 & 0.7 & 0.01 & 0.54 & 0.01 & 0.8 \\
$\mathbf{1 5 8}$ & 0 & 0.94 & 0.01 & 0.63 & 0 & 1.19 & 0.01 & 0.7 & 0.01 & 0.54 & 0.02 & 0.8 \\
$\mathbf{1 5 9}$ & 2.68 & 2.02 & 0.72 & 0.85 & 2.94 & 1.98 & 1.42 & 1.81 & 0.51 & 0.79 & 2.69 \\
$\mathbf{1 6 0}$ & 3.89 & 2.89 & 1.32 & 1.1 & 3.68 & 2.17 & 2.81 & 1.5 & 1.53 & 0.97 & 3.26 & 1.48 \\
$\mathbf{1 6 1}$ & 0.98 & 1.33 & 0.23 & 0.43 & 1.13 & 1.02 & 1.14 & 1.14 & 0.3 & 0.66 & 1.59 & 1.19 \\
$\mathbf{1 6 2}$ & 0.04 & 0.02 & 0.01 & 0.01 & 0.05 & 0.02 & 0.12 & 0.05 & 0.01 & 0 & 0.51 & 0.16 \\
$\mathbf{1 6 3}$ & 0 & 0 & 0.01 & 0.01 & 0 & 0 & 0 & 0 & 0 & 0 & 0 & 0 \\
\hline
\end{tabular}

\section{Appendix B. Complete Forward and Backward Linkage Charts}

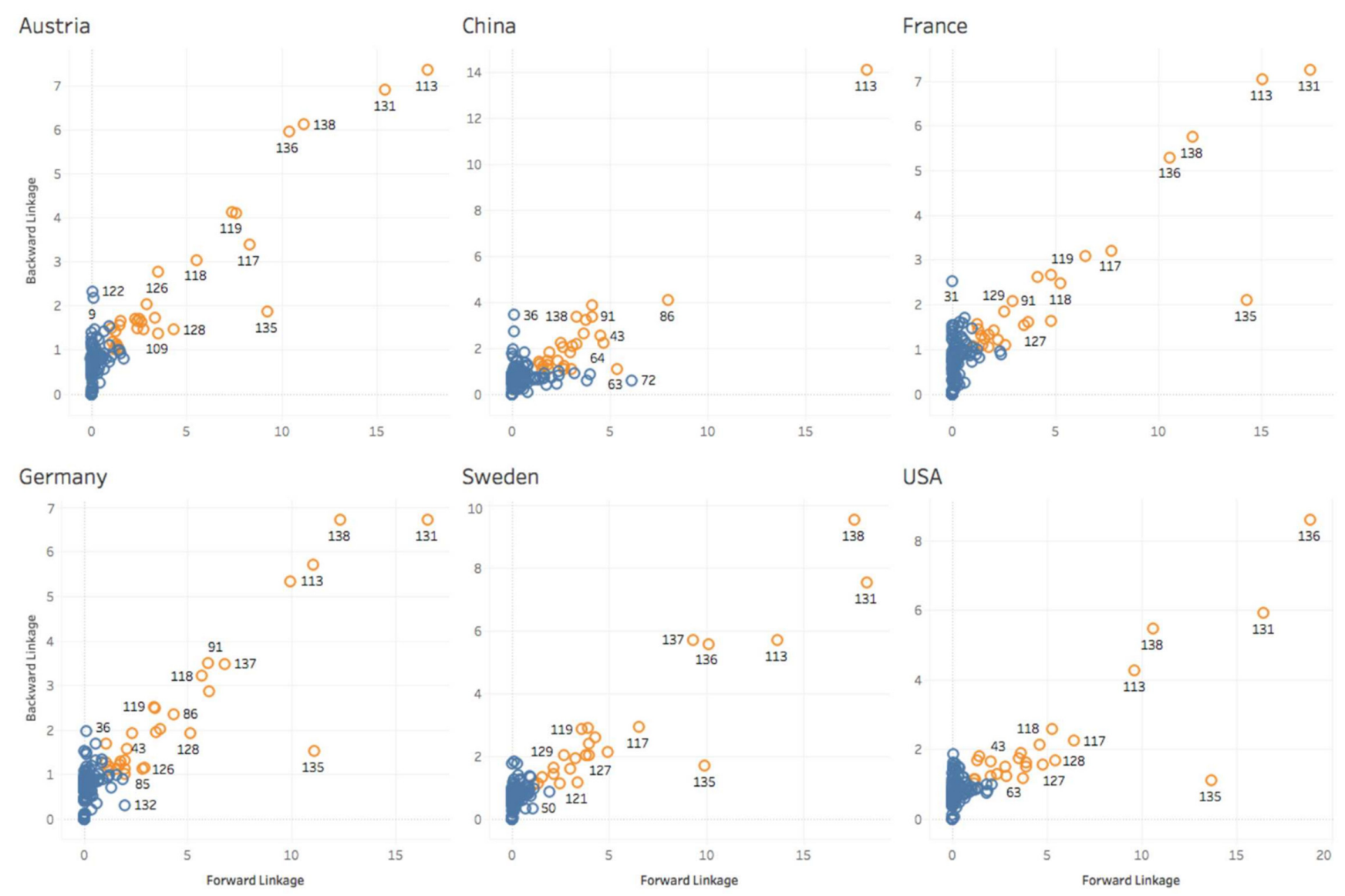

Figure A1. Final demand-weighted forward and backward linkage coefficient comparison for the six countries (sector ID index can be found in Appendix D: Multi-criteria decision analysis results summary). 

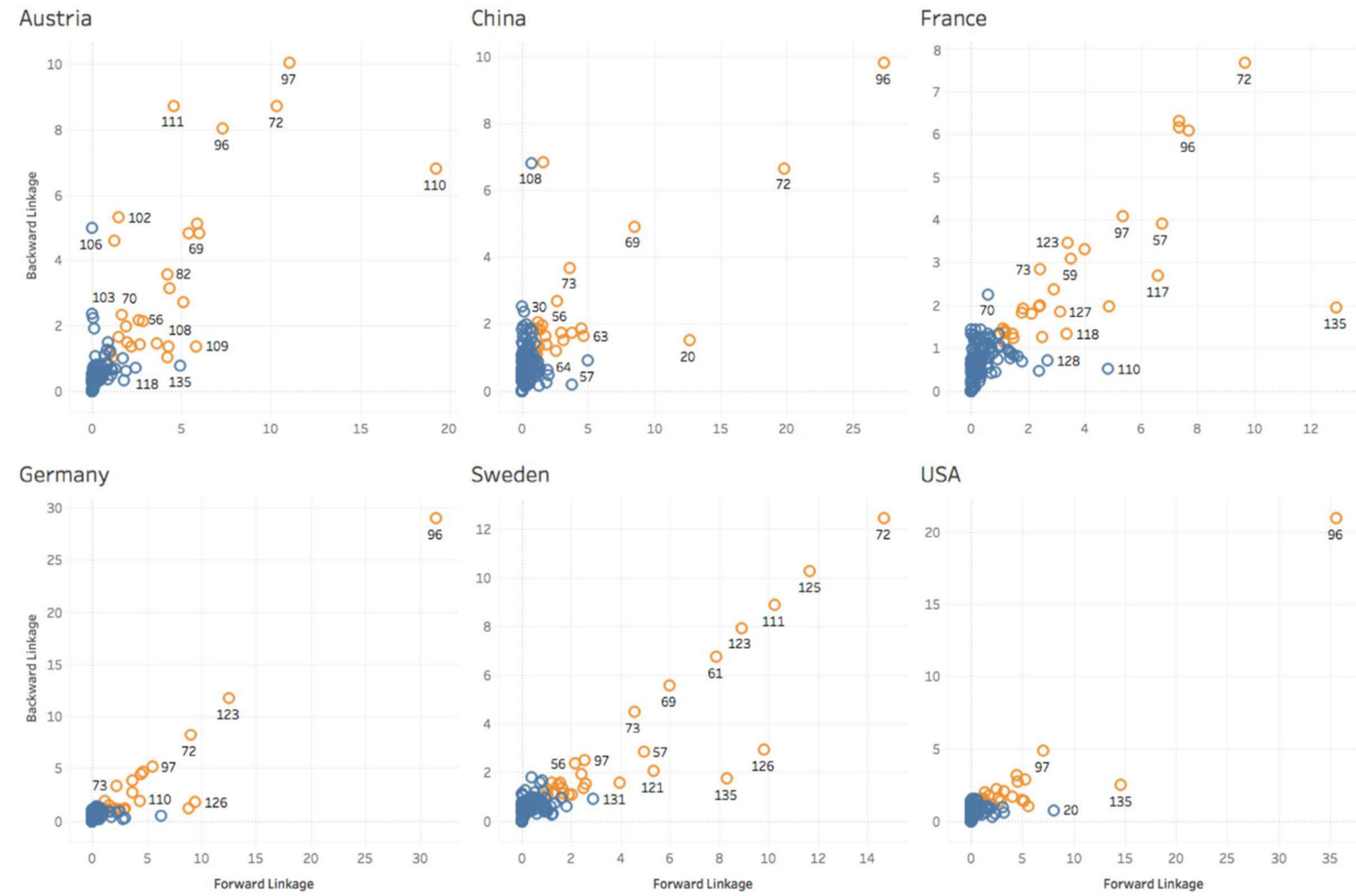

\section{Sweden}

USA
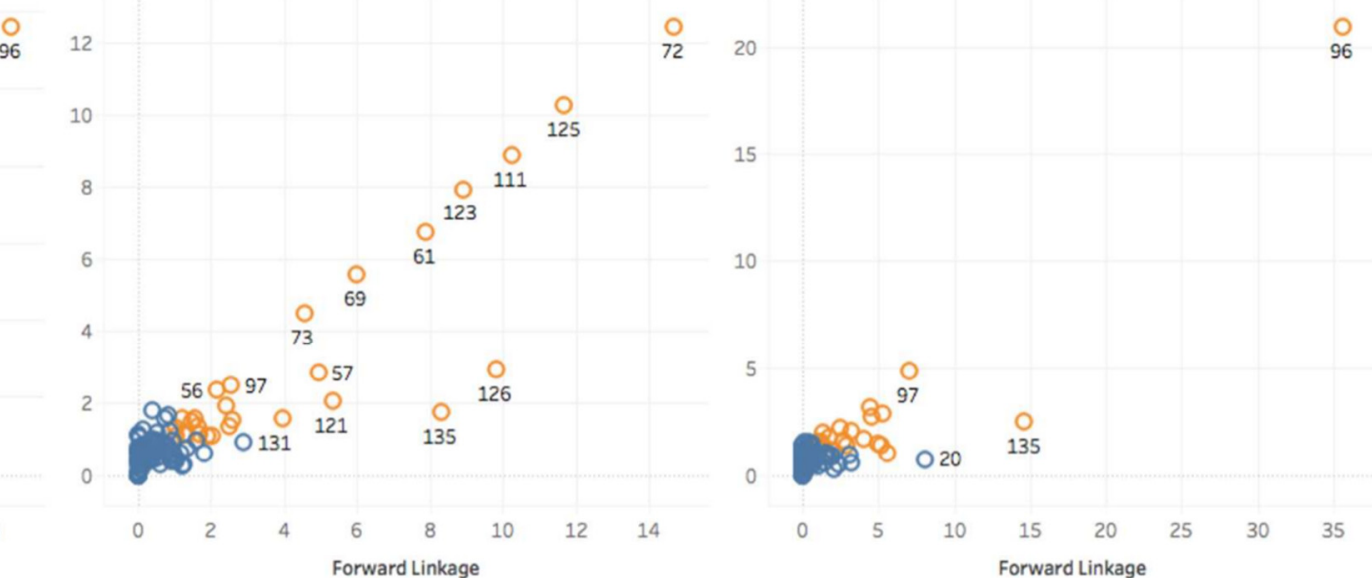

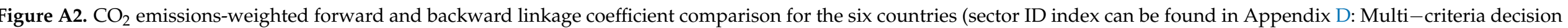
analysis results summary). 


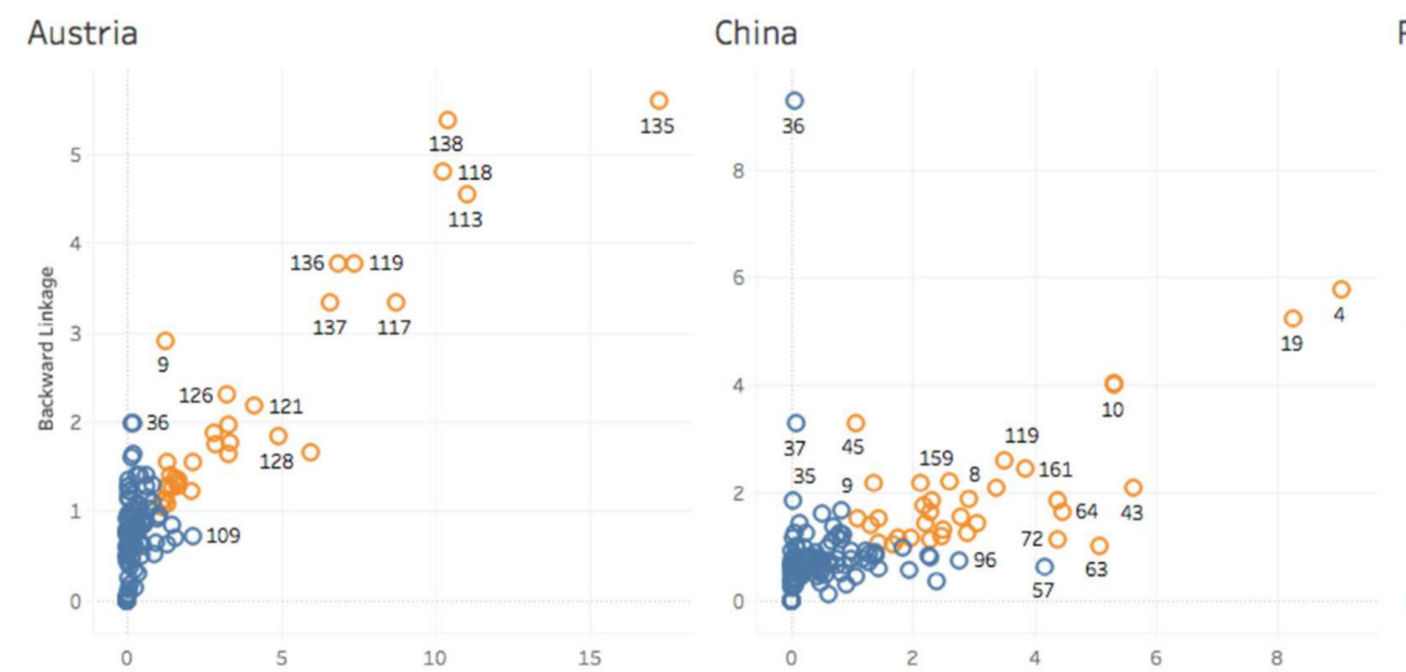

France

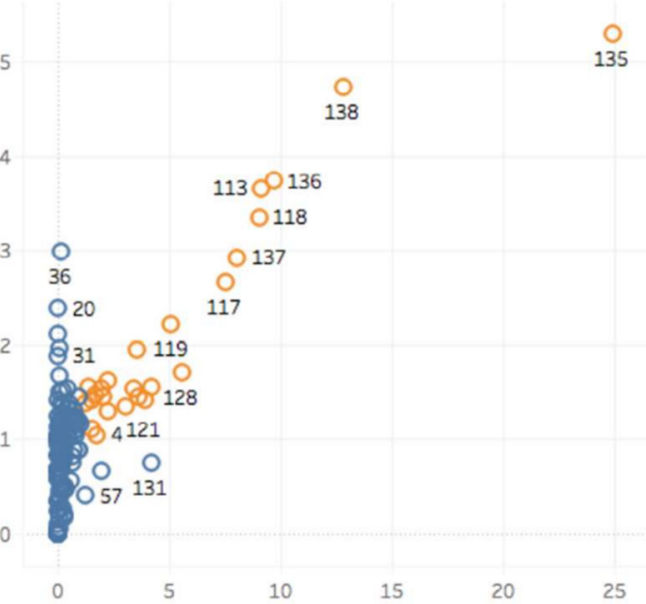

\section{Germany}
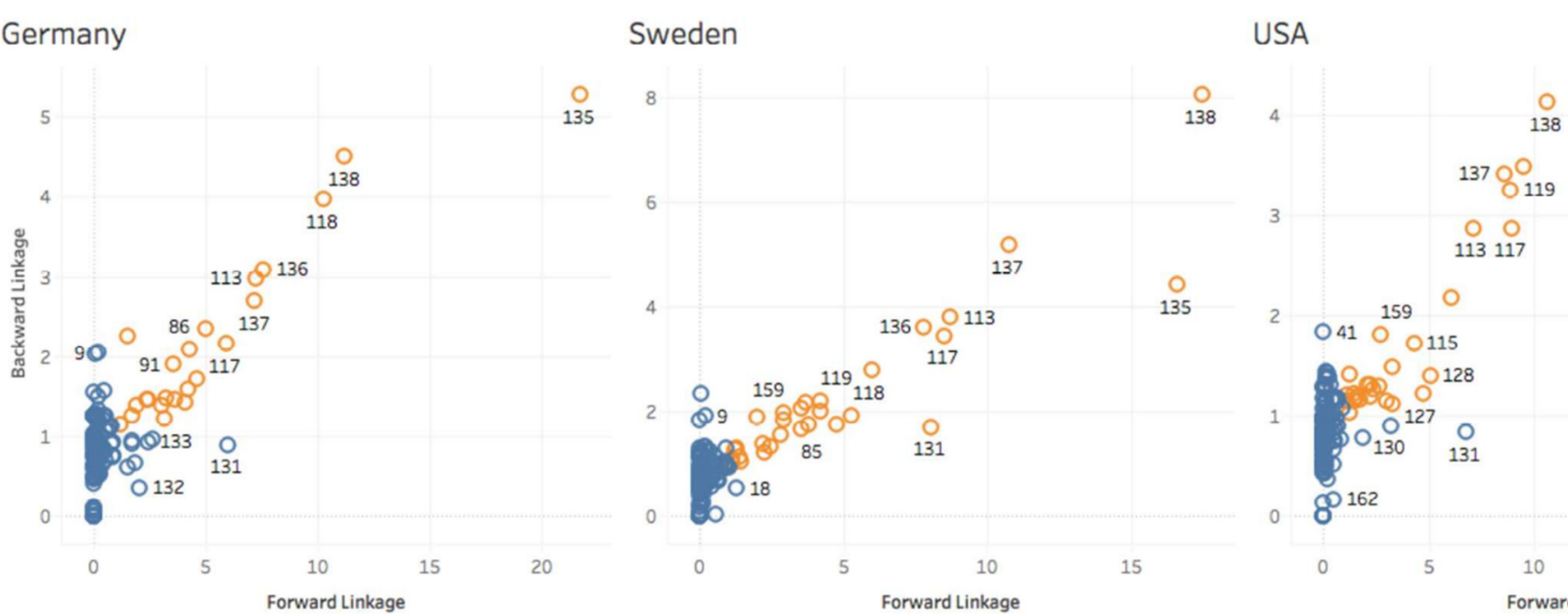

Forward Linkage

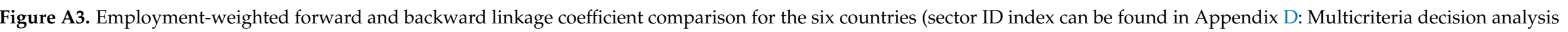
results summary) 


\section{Appendix C. Linkage Coefficient Trade-Off Charts}

Figures A4-A7 show the trade-offs between linkage coefficients for final demand, $\mathrm{CO}_{2}$ emissions, and employment for each of the six countries observed in this study. This is intended as an alternative way to visualize the EE I-O key sector analysis results. The average of the forward and backwards coefficients was used for each data point. The average $\mathrm{CO}_{2}$ linkages and final demand linkages are shown on each $\mathrm{x}$ - and y-axis, respectively, and the size of the circles encodes the average employment linkage. The most sustainable sectors tend to coalesce at the top-left quadrant of each graph, and are those with relatively high average employment linkage coefficients.

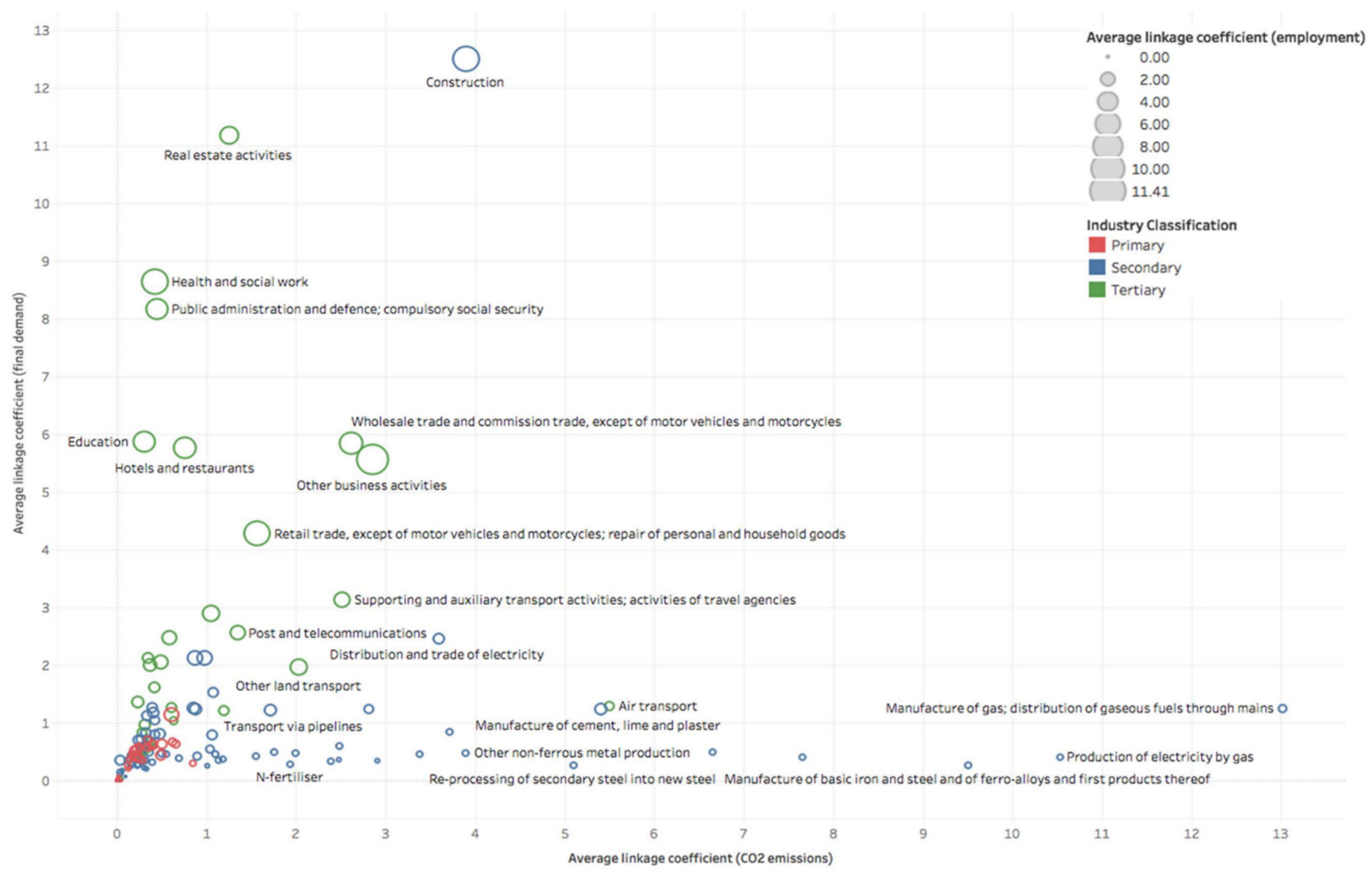

Figure A4. Trade-off of average forward and backward linkage coefficients (Austria). 


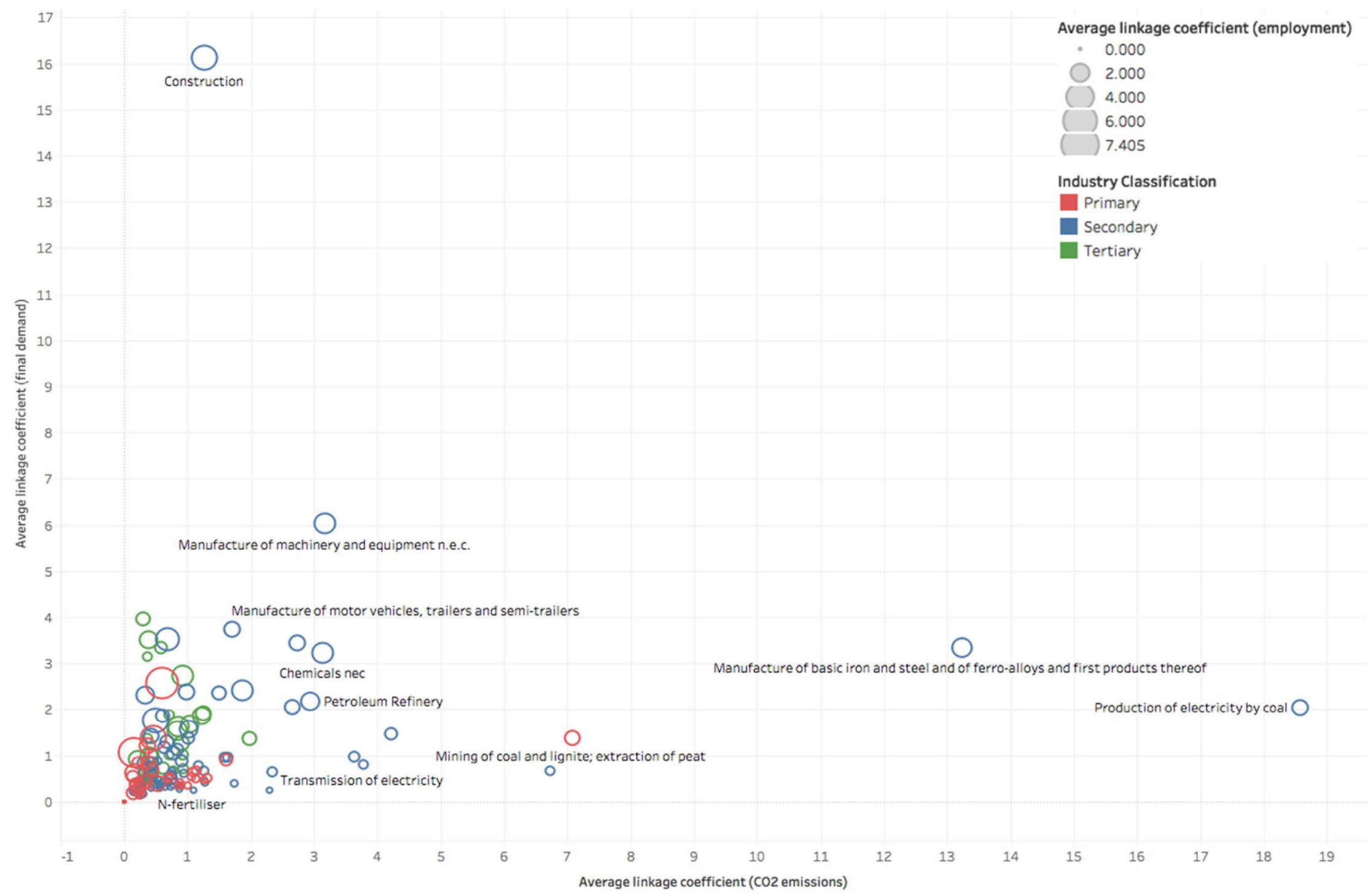

Figure A5. Trade-off of average forward and backward linkage coefficients (China). 


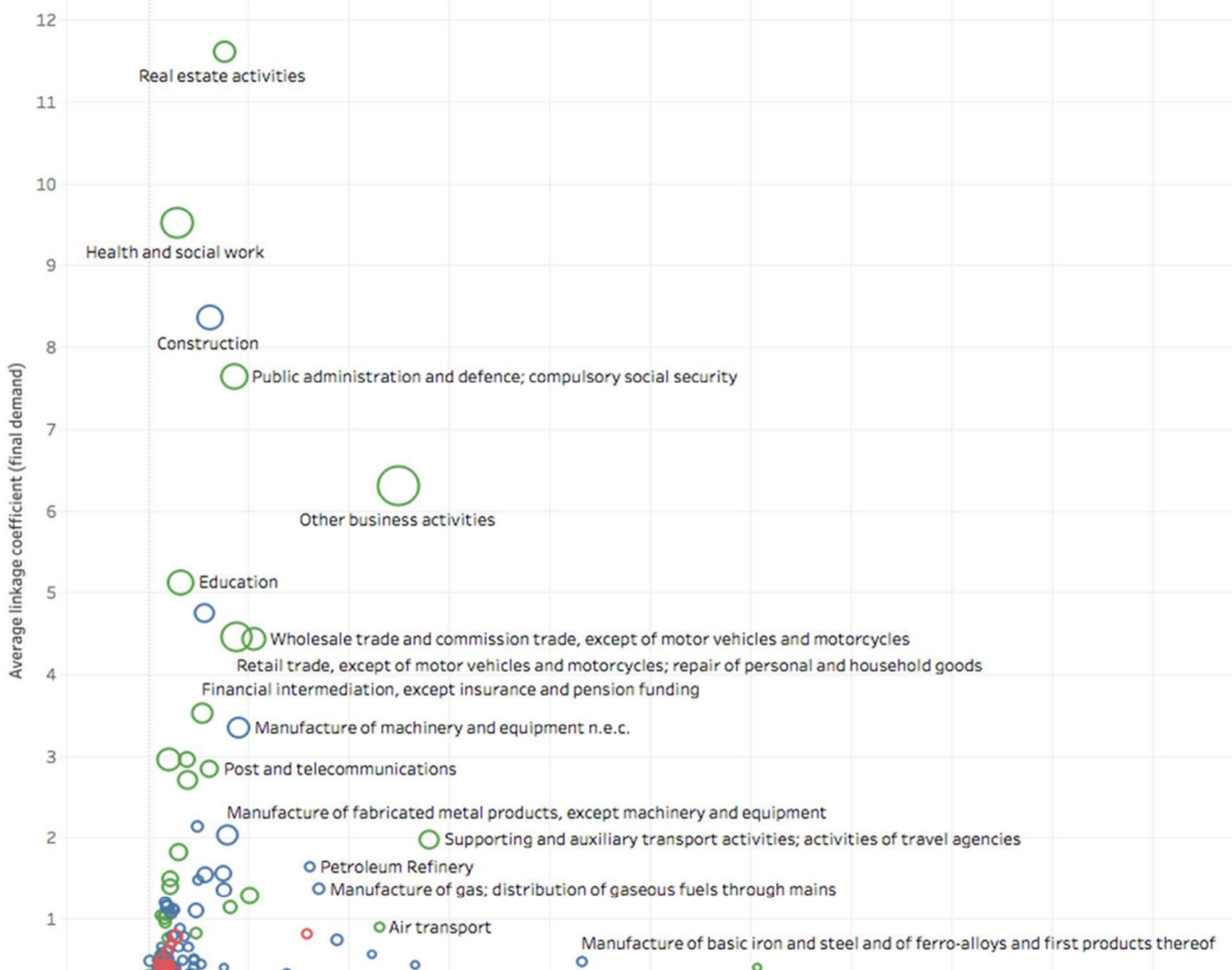

$\begin{array}{lcc}\circ & \circ & \text { Manufacture } \\ \text { Re-processing of secondary steel into new steel }\end{array}$ -
12
14

18
nissions)

Figure A6. Trade-off of average forward and backward linkage coefficients (Germany).

\section{Average linkage coefficient (employment)}

- 0.00

5.00

10.00

13.47

Industry Classification

Primary

Secondary

Tertiary

Production of electricity by coal 0

26

28

30 


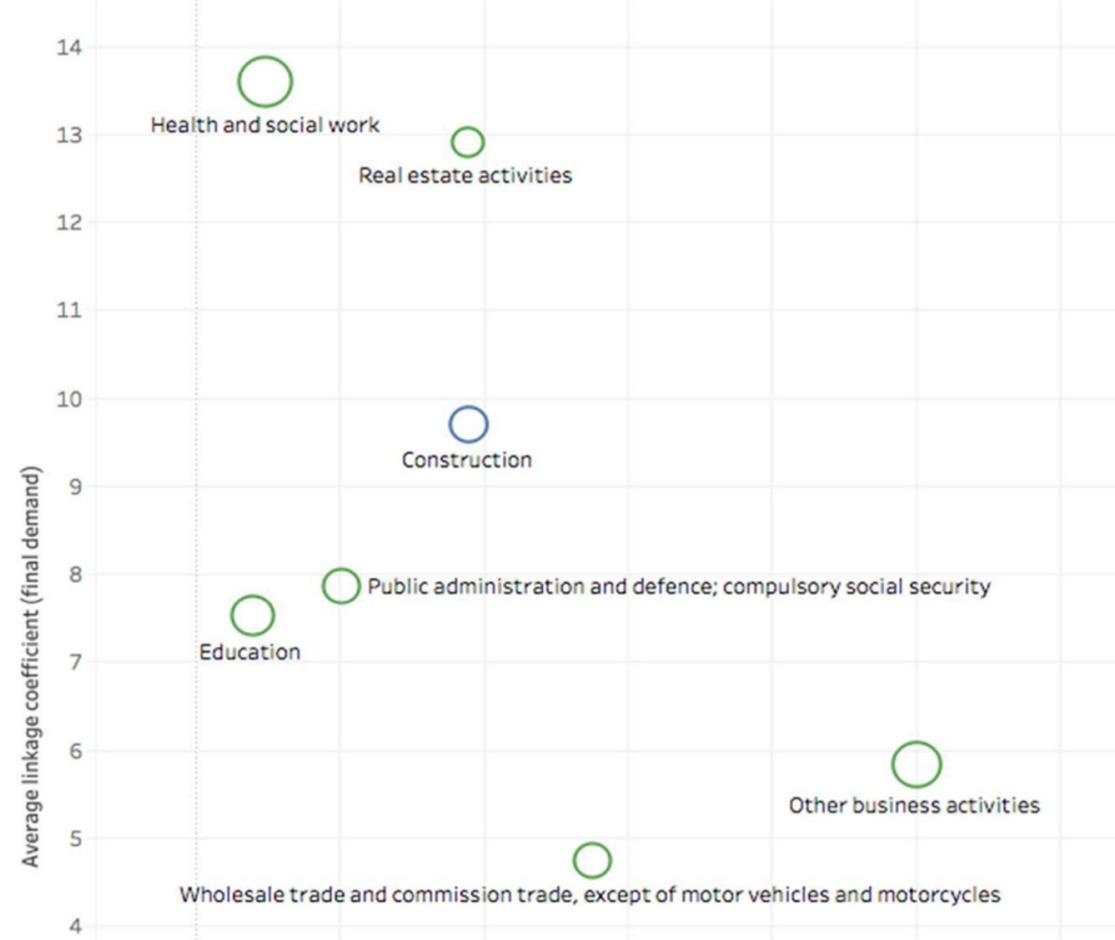

Average linkage coefficient (employment)

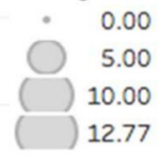

\section{Industry Classification}

Primary

Secondary

Tertiary

$\bigcirc 8$ Supporting and auxiliary transport activities; activities of travel agencies (1) Manufacture of machinery and equipment n.e.c.

- 0 Other land transport

- 1 Manufacture of fabricated metal products, except machinery and equipment

o Petroleum Refinery O Manufacture of cement, lime and plaster

Mining of iron ores ${ }^{\circ} \quad$ Re-processing of secondary steel into new steel._. N-fertiliser Manufacture of basic iron and steel and of ferro-alloys and first products thereof

Figure A7. Trade-off of average forward and backward linkage coefficients (Sweden). 


\section{Appendix D. Multi-Criteria Decision Analysis Results Summary}

Table A2. Complete sector sustainability rankings for all six countries, by number of other sectors outranked.

\begin{tabular}{|c|c|c|c|c|c|c|c|}
\hline \multirow[b]{2}{*}{ Sector ID } & \multirow[b]{2}{*}{ Sector Name } & \multicolumn{6}{|c|}{ Overall Sustainability Ranking, by Country } \\
\hline & & Austria & China & France & Germany & Sweden & USA \\
\hline 1 & Cultivation of paddy rice & 138 & 74 & 153 & 144 & 141 & 37 \\
\hline 2 & Cultivation of wheat & 39 & 29 & 118 & 66 & 118 & 31 \\
\hline 3 & Cultivation of cereal grains nec & 92 & 25 & 141 & 68 & 97 & 111 \\
\hline 4 & Cultivation of vegetables, fruit, nuts & 68 & 4 & 81 & 59 & 126 & 27 \\
\hline 5 & Cultivation of oil seeds & 101 & 28 & 139 & 86 & 108 & 39 \\
\hline 6 & Cultivation of sugar cane, sugar beet & 87 & 26 & 120 & 79 & 57 & 59 \\
\hline 7 & Cultivation of plant-based fibers & 138 & 58 & 153 & 144 & 141 & 62 \\
\hline 8 & Cultivation of crops nec & 14 & 7 & 141 & 22 & 17 & 23 \\
\hline 9 & Cattle farming & 7 & 23 & 104 & 16 & 14 & 15 \\
\hline 10 & Pigs farming & 19 & 8 & 54 & 25 & 22 & 64 \\
\hline 11 & Poultry farming & 31 & 13 & 42 & 113 & 75 & 34 \\
\hline 12 & Meat animals nec & 138 & 15 & 100 & 131 & 97 & 88 \\
\hline 13 & Animal products nec & 138 & 17 & 153 & 144 & 97 & 55 \\
\hline 14 & Raw milk & 15 & 31 & 44 & 54 & 47 & 48 \\
\hline 15 & Wool, silk-worm cocoons & 95 & 51 & 91 & 81 & 62 & 54 \\
\hline 16 & $\begin{array}{c}\text { Manure treatment (conventional), storage and } \\
\text { land application }\end{array}$ & 138 & 146 & 153 & 144 & 141 & 153 \\
\hline 17 & $\begin{array}{c}\text { Manure treatment (biogas), storage and } \\
\text { land application }\end{array}$ & 138 & 146 & 153 & 144 & 141 & 153 \\
\hline 18 & Forestry, logging and related service activities & 97 & 17 & 99 & 116 & 112 & 102 \\
\hline 19 & $\begin{array}{l}\text { Fishing, operating of fish hatcheries and fish } \\
\text { farms; service activities incidental to fishing }\end{array}$ & 31 & 3 & 127 & 138 & 104 & 95 \\
\hline 20 & $\begin{array}{l}\text { Mining of coal and lignite; extraction of peat } \\
\text { Extraction of crude petroleum and services }\end{array}$ & 53 & 93 & 4 & 123 & 123 & 152 \\
\hline 21 & $\begin{array}{c}\text { related to crude oil extraction, } \\
\text { excluding surveying }\end{array}$ & 105 & 106 & 50 & 90 & 141 & 108 \\
\hline 22 & $\begin{array}{l}\text { Extraction of natural gas and services related } \\
\text { to natural gas extraction, excluding surveying }\end{array}$ & 132 & 140 & 48 & 86 & 141 & 134 \\
\hline 23 & $\begin{array}{l}\text { Extraction, liquefaction, and regasification of } \\
\text { other petroleum and gaseous materials }\end{array}$ & 138 & 146 & 127 & 89 & 141 & 111 \\
\hline 24 & Mining of uranium and thorium ores & 138 & 136 & 127 & 72 & 141 & 150 \\
\hline 25 & Mining of iron ores & 31 & 113 & 127 & 75 & 135 & 64 \\
\hline 26 & Mining of copper ores and concentrates & 138 & 128 & 127 & 144 & 134 & 149 \\
\hline 27 & Mining of nickel ores and concentrates & 138 & 136 & 127 & 144 & 141 & 153 \\
\hline 28 & Mining of aluminium ores and concentrates & 138 & 130 & 22 & 144 & 141 & 147 \\
\hline 29 & Mining of precious metal ores and concentrates & 138 & 130 & 153 & 144 & 132 & 135 \\
\hline 30 & $\begin{array}{l}\text { Mining of lead, zinc and tin ores } \\
\text { and concentrates }\end{array}$ & 138 & 99 & 127 & 92 & 102 & 147 \\
\hline 31 & $\begin{array}{l}\text { Mining of other non-ferrous metal ores } \\
\text { and concentrates }\end{array}$ & 91 & 107 & 10 & 81 & 104 & 127 \\
\hline 32 & Quarrying of stone & 35 & 118 & 121 & 90 & 86 & 123 \\
\hline 33 & Quarrying of sand and clay & 95 & 102 & 125 & 113 & 119 & 114 \\
\hline 34 & $\begin{array}{c}\text { Mining of chemical and fertilizer minerals, } \\
\text { production of salt, other mining and } \\
\text { quarrying n.e.c. }\end{array}$ & 39 & 73 & 57 & 83 & 74 & 110 \\
\hline 35 & Processing of meat cattle & 21 & 32 & 23 & 19 & 15 & 20 \\
\hline 36 & Processing of meat pigs & 8 & 21 & 3 & 15 & 51 & 34 \\
\hline 37 & Processing of meat poultry & 107 & 27 & 8 & 131 & 5 & 20 \\
\hline 38 & Production of meat products nec & 30 & 44 & 6 & 64 & 21 & 38 \\
\hline 39 & Processing vegetable oils and fats & 77 & 50 & 111 & 61 & 141 & 32 \\
\hline 40 & Processing of dairy products & 26 & 40 & 54 & 48 & 64 & 14 \\
\hline 41 & Processed rice & 138 & 136 & 153 & 144 & 47 & 15 \\
\hline 42 & Sugar refining & 102 & 36 & 73 & 108 & 92 & 40 \\
\hline 43 & Processing of Food products nec & 77 & 5 & 98 & 74 & 52 & 88 \\
\hline 44 & Manufacture of beverages & 18 & 33 & 29 & 45 & 13 & 10 \\
\hline
\end{tabular}


Table A2. Cont.

\begin{tabular}{|c|c|c|c|c|c|c|c|}
\hline \multirow[b]{2}{*}{ Sector ID } & \multirow[b]{2}{*}{ Sector Name } & \multicolumn{6}{|c|}{ Overall Sustainability Ranking, by Country } \\
\hline & & Austria & China & France & Germany & Sweden & USA \\
\hline 45 & Manufacture of fish products & 27 & 6 & 32 & 58 & 20 & 71 \\
\hline 46 & Manufacture of tobacco products & 81 & 55 & 67 & 63 & 141 & 96 \\
\hline 47 & Manufacture of textiles & 81 & 46 & 50 & 62 & 62 & 23 \\
\hline 48 & $\begin{array}{c}\text { Manufacture of wearing apparel; dressing and } \\
\text { dyeing of fur }\end{array}$ & 27 & 24 & 9 & 51 & 59 & 28 \\
\hline 49 & $\begin{array}{c}\text { Tanning and dressing of leather; manufacture } \\
\text { of luggage, handbags, saddlery, harness } \\
\text { and footwear }\end{array}$ & 44 & 36 & 61 & 95 & 57 & 48 \\
\hline 50 & $\begin{array}{c}\text { Manufacture of wood and of products of wood } \\
\text { and cork, except furniture; manufacture of } \\
\text { articles ... }\end{array}$ & 67 & 105 & 32 & 23 & 83 & 47 \\
\hline 51 & $\begin{array}{l}\text { Re-processing of secondary wood material into } \\
\text { new wood material }\end{array}$ & 29 & 130 & 47 & 86 & 84 & 87 \\
\hline 52 & Pulp & 50 & 122 & 50 & 113 & 120 & 62 \\
\hline 53 & $\begin{array}{l}\text { Re-processing of secondary paper into } \\
\text { new pulp }\end{array}$ & 123 & 122 & 78 & 93 & 123 & 96 \\
\hline 54 & Paper & 70 & 62 & 29 & 52 & 69 & 84 \\
\hline 55 & $\begin{array}{l}\text { Publishing, printing and reproduction of } \\
\text { recorded media }\end{array}$ & 89 & 53 & 72 & 75 & 110 & 77 \\
\hline 56 & Manufacture of coke oven products & 134 & 133 & 150 & 140 & 138 & 43 \\
\hline 57 & Petroleum Refinery & 117 & 83 & 113 & 118 & 116 & 144 \\
\hline 58 & Processing of nuclear fuel & 53 & 56 & 23 & 104 & 78 & 107 \\
\hline 59 & Plastics, basic & 99 & 89 & 116 & 112 & 100 & 45 \\
\hline 60 & $\begin{array}{c}\text { Re-processing of secondary plastic into } \\
\text { new plastic }\end{array}$ & 97 & 93 & 115 & 85 & 53 & 51 \\
\hline 61 & $\mathrm{~N}$-fertiliser & 134 & 143 & 141 & 139 & 141 & 144 \\
\hline 62 & P- and other fertiliser & 106 & 97 & 32 & 104 & 86 & 131 \\
\hline 63 & Chemicals nec & 107 & 71 & 92 & 110 & 49 & 119 \\
\hline 64 & Manufacture of rubber and plastic products & 49 & 53 & 83 & 98 & 67 & 96 \\
\hline 65 & Manufacture of glass and glass products & 87 & 60 & 139 & 123 & 126 & 144 \\
\hline 66 & $\begin{array}{l}\text { Re-processing of secondary glass into } \\
\text { new glass }\end{array}$ & 90 & 146 & 117 & 71 & 115 & 117 \\
\hline 67 & Manufacture of ceramic goods & 85 & 42 & 112 & 102 & 86 & 103 \\
\hline 68 & $\begin{array}{l}\text { Manufacture of bricks, tiles and construction } \\
\text { products, in baked clay }\end{array}$ & 129 & 141 & 126 & 108 & 95 & 108 \\
\hline 69 & Manufacture of cement, lime and plaster & 114 & 146 & 121 & 123 & 112 & 139 \\
\hline 70 & Re-processing of ash into clinker & 126 & 143 & 124 & 129 & 123 & 96 \\
\hline 71 & $\begin{array}{c}\text { Manufacture of other non-metallic mineral } \\
\text { products n.e.c. }\end{array}$ & 125 & 102 & 121 & 127 & 122 & 105 \\
\hline 72 & $\begin{array}{l}\text { Manufacture of basic iron and steel and of } \\
\text { ferro-alloys and first products thereof }\end{array}$ & 138 & 120 & 153 & 136 & 141 & 131 \\
\hline 73 & Re-processing of secondary steel into new steel & 136 & 124 & 149 & 143 & 138 & 74 \\
\hline 74 & Precious metals production & 103 & 118 & 16 & 118 & 67 & 93 \\
\hline 75 & $\begin{array}{l}\text { Re-processing of secondary precious metals } \\
\text { into new precious metals }\end{array}$ & 138 & 146 & 127 & 144 & 141 & 82 \\
\hline 76 & Aluminium production & 127 & 109 & 114 & 140 & 135 & 139 \\
\hline 77 & $\begin{array}{l}\text { Re-processing of secondary aluminium into } \\
\text { new aluminium }\end{array}$ & 107 & 124 & 38 & 101 & 95 & 59 \\
\hline 78 & Lead, zinc and tin production & 121 & 97 & 65 & 121 & 126 & 138 \\
\hline 79 & Re-processing of secondary lead into new lead & 120 & 128 & 75 & 118 & 90 & 135 \\
\hline 80 & Copper production & 103 & 114 & 110 & 127 & 78 & 90 \\
\hline 81 & $\begin{array}{c}\text { Re-processing of secondary copper into } \\
\text { new copper }\end{array}$ & 107 & 133 & 127 & 123 & 75 & 96 \\
\hline 82 & Other non-ferrous metal production & 133 & 100 & 36 & 102 & 78 & 64 \\
\hline 83 & $\begin{array}{l}\text { Re-processing of secondary other non-ferrous } \\
\text { metals into new other non-ferrous metals }\end{array}$ & 138 & 146 & 127 & 144 & 16 & 51 \\
\hline 84 & Casting of metals & 115 & 126 & 119 & 135 & 131 & 92 \\
\hline
\end{tabular}


Table A2. Cont.

\begin{tabular}{|c|c|c|c|c|c|c|c|}
\hline \multirow[b]{2}{*}{ Sector ID } & \multirow[b]{2}{*}{ Sector Name } & \multicolumn{6}{|c|}{ Overall Sustainability Ranking, by Country } \\
\hline & & Austria & China & France & Germany & Sweden & USA \\
\hline 85 & $\begin{array}{l}\text { Manufacture of fabricated metal products, } \\
\text { except machinery and equipment }\end{array}$ & 45 & 110 & 65 & 83 & 78 & 43 \\
\hline 86 & $\begin{array}{c}\text { Manufacture of machinery and } \\
\text { equipment n.e.c. }\end{array}$ & 47 & 79 & 37 & 65 & 70 & 33 \\
\hline 87 & $\begin{array}{c}\text { Manufacture of office machinery and } \\
\text { computers }\end{array}$ & 42 & 47 & 44 & 56 & 65 & 15 \\
\hline 88 & $\begin{array}{c}\text { Manufacture of electrical machinery and } \\
\text { apparatus n.e.c. }\end{array}$ & 56 & 71 & 78 & 54 & 40 & 40 \\
\hline 89 & $\begin{array}{l}\text { Manufacture of radio, television and } \\
\text { communication equipment and apparatus }\end{array}$ & 20 & 42 & 16 & 10 & 10 & 25 \\
\hline 90 & $\begin{array}{l}\text { Manufacture of medical, precision and optical } \\
\text { instruments, watches and clocks }\end{array}$ & 12 & 56 & 42 & 9 & 19 & 11 \\
\hline 91 & $\begin{array}{c}\text { Manufacture of motor vehicles, trailers and } \\
\text { semi-trailers }\end{array}$ & 22 & 66 & 31 & 53 & 59 & 28 \\
\hline 92 & Manufacture of other transport equipment & 74 & 76 & 68 & 100 & 54 & 13 \\
\hline 93 & Manufacture of furniture; manufacturing n.e.c. & 24 & 30 & 14 & 14 & 45 & 8 \\
\hline 94 & Recycling of waste and scrap & 127 & 146 & 141 & 111 & 130 & 103 \\
\hline 95 & Recycling of bottles by direct reuse & 138 & 146 & 141 & 144 & 141 & 153 \\
\hline 96 & Production of electricity by coal & 138 & 146 & 153 & 144 & 132 & 153 \\
\hline 97 & Production of electricity by gas & 138 & 143 & 153 & 144 & 138 & 153 \\
\hline 98 & Production of electricity by nuclear & 138 & 112 & 26 & 75 & 102 & 139 \\
\hline 99 & Production of electricity by hydro & 115 & 117 & 11 & 80 & 84 & 135 \\
\hline 100 & Production of electricity by wind & 123 & 107 & 15 & 70 & 70 & 129 \\
\hline 101 & $\begin{array}{c}\text { Production of electricity by petroleum and } \\
\text { other oil derivatives }\end{array}$ & 138 & 141 & 150 & 140 & 135 & 153 \\
\hline 102 & Production of electricity by biomass and waste & 136 & 78 & 147 & 129 & 126 & 116 \\
\hline 103 & Production of electricity by solar photovoltaic & 122 & 100 & 13 & 72 & 86 & 114 \\
\hline 104 & Production of electricity by solar thermal & 138 & 146 & 127 & 144 & 141 & 123 \\
\hline 105 & Production of electricity by tide, wave, ocean & 138 & 146 & 75 & 144 & 141 & 153 \\
\hline 106 & Production of electricity by Geothermal & 129 & 102 & 127 & 144 & 141 & 123 \\
\hline 107 & Production of electricity nec & 129 & 120 & 78 & 97 & 91 & 118 \\
\hline 108 & Transmission of electricity & 111 & 110 & 77 & 96 & 104 & 130 \\
\hline 109 & Distribution and trade of electricity & 99 & 114 & 54 & 106 & 33 & 48 \\
\hline 110 & $\begin{array}{c}\text { Manufacture of gas; distribution of gaseous } \\
\text { fuels through mains }\end{array}$ & 119 & 133 & 108 & 20 & 104 & 113 \\
\hline 111 & Steam and hot water supply & 138 & 146 & 152 & 137 & 141 & 151 \\
\hline 112 & $\begin{array}{l}\text { Collection, purification and distribution } \\
\text { of water }\end{array}$ & 37 & 136 & 48 & 75 & 28 & 42 \\
\hline 113 & Construction & 111 & 33 & 87 & 36 & 70 & 73 \\
\hline 114 & $\begin{array}{l}\text { Re-processing of secondary construction } \\
\text { material into aggregates }\end{array}$ & 113 & 146 & 108 & 131 & 101 & 139 \\
\hline 115 & $\begin{array}{c}\text { Sale, maintenance, repair of motor vehicles, } \\
\text { motor vehicles parts, motorcycles, motor } \\
\text { cycles parts ... }\end{array}$ & 12 & 22 & 21 & 6 & 12 & 3 \\
\hline 116 & Retail sale of automotive fuel & 9 & 79 & 41 & 16 & 50 & 36 \\
\hline 117 & $\begin{array}{c}\text { Wholesale trade and commission trade, except } \\
\text { of motor vehicles and motorcycles }\end{array}$ & 50 & 12 & 100 & 68 & 75 & 28 \\
\hline 118 & $\begin{array}{c}\text { Retail trade, except of motor vehicles and } \\
\text { motorcycles; repair of personal and } \\
\text { household goods }\end{array}$ & 43 & 17 & 53 & 59 & 54 & 91 \\
\hline 119 & Hotels and restaurants & 9 & 9 & 20 & 3 & 3 & 12 \\
\hline 120 & Transport via railways & 77 & 96 & 73 & 107 & 70 & 119 \\
\hline 121 & Other land transport & 74 & 38 & 90 & 93 & 108 & 101 \\
\hline 122 & Transport via pipelines & 93 & 85 & 26 & 12 & 78 & 127 \\
\hline 123 & Sea and coastal water transport & 38 & 90 & 141 & 144 & 114 & 93 \\
\hline 124 & Inland water transport & 41 & 127 & 64 & 121 & 121 & 46 \\
\hline 125 & Air transport & 117 & 65 & 147 & 134 & 116 & 139 \\
\hline
\end{tabular}


Table A2. Cont.

\begin{tabular}{|c|c|c|c|c|c|c|c|}
\hline \multirow[b]{2}{*}{ Sector ID } & \multirow[b]{2}{*}{ Sector Name } & \multicolumn{6}{|c|}{ Overall Sustainability Ranking, by Country } \\
\hline & & Austria & China & France & Germany & Sweden & USA \\
\hline 126 & $\begin{array}{l}\text { Supporting and auxiliary transport activities; } \\
\text { activities of travel agencies }\end{array}$ & 68 & 20 & 102 & 116 & 111 & 78 \\
\hline 127 & Post and telecommunications & 61 & 48 & 85 & 56 & 92 & 119 \\
\hline 128 & $\begin{array}{l}\text { Financial intermediation, except insurance and } \\
\text { pension funding }\end{array}$ & 5 & 114 & 5 & 4 & 4 & 4 \\
\hline 129 & $\begin{array}{c}\text { Insurance and pension funding, except } \\
\text { compulsory social security }\end{array}$ & 11 & 44 & 11 & 6 & 9 & 5 \\
\hline 130 & Activities auxiliary to financial intermediation & 15 & 66 & 25 & 30 & 11 & 15 \\
\hline 131 & Real estate activities & 35 & 40 & 32 & 5 & 45 & 19 \\
\hline 132 & $\begin{array}{l}\text { Renting of machinery and equipment without } \\
\text { operator and of personal and household goods }\end{array}$ & 71 & 60 & 68 & 98 & 65 & 105 \\
\hline 133 & Computer and related activities & 6 & 68 & 18 & 13 & 5 & 7 \\
\hline 134 & Research and development & 17 & 62 & 40 & 8 & 43 & 25 \\
\hline 135 & Other business activities & 45 & 33 & 82 & 67 & 94 & 133 \\
\hline 136 & $\begin{array}{l}\text { Public administration and defence; } \\
\text { compulsory social security }\end{array}$ & 3 & 2 & 6 & 38 & 7 & 126 \\
\hline 137 & Education & 3 & 1 & 2 & 2 & 2 & 1 \\
\hline 138 & Health and social work & 2 & 16 & $\overline{1}$ & 1 & 1 & 2 \\
\hline 139 & Incineration of waste: Food & 56 & 81 & 94 & 31 & 28 & 83 \\
\hline 140 & Incineration of waste: Paper & 53 & 81 & 94 & 26 & 22 & 86 \\
\hline 141 & Incineration of waste: Plastic & 48 & 83 & 85 & 26 & 25 & 74 \\
\hline 142 & $\begin{array}{c}\text { Incineration of waste: Metals and } \\
\text { Inert materials }\end{array}$ & 34 & 92 & 104 & 23 & 61 & 70 \\
\hline 143 & Incineration of waste: Textiles & 81 & 85 & 68 & 47 & 34 & 78 \\
\hline 144 & Incineration of waste: Wood & 74 & 85 & 83 & 31 & 28 & 78 \\
\hline 145 & Incineration of waste: Oil/Hazardous waste & 52 & 85 & 94 & 26 & 28 & 78 \\
\hline 146 & $\begin{array}{l}\text { Biogasification of food waste, incl. } \\
\text { land application }\end{array}$ & 72 & 146 & 62 & 38 & 28 & 153 \\
\hline 147 & Biogasification of paper, incl. land application & 62 & 146 & 57 & 40 & 22 & 153 \\
\hline 148 & $\begin{array}{c}\text { Biogasification of sewage sludge, incl. } \\
\text { land application }\end{array}$ & 62 & 146 & 94 & 26 & 18 & 53 \\
\hline 149 & $\begin{array}{l}\text { Composting of food waste, incl. } \\
\text { land application }\end{array}$ & 86 & 93 & 92 & 33 & 41 & 84 \\
\hline 150 & $\begin{array}{l}\text { Composting of paper and wood, incl. } \\
\text { land application }\end{array}$ & 59 & 91 & 57 & 48 & 141 & 74 \\
\hline 151 & Waste water treatment, food & 81 & 59 & 103 & 35 & 43 & 68 \\
\hline 152 & Waste water treatment, other & 77 & 49 & 106 & 33 & 41 & 59 \\
\hline 153 & Landfill of waste: Food & 62 & 52 & 89 & 40 & 36 & 56 \\
\hline 154 & Landfill of waste: Paper & 72 & 62 & 87 & 40 & 34 & 56 \\
\hline 155 & Landfill of waste: Plastic & 62 & 69 & 62 & 40 & 36 & 64 \\
\hline 156 & Landfill of waste: Inert/metal/hazardous & 59 & 69 & 106 & 36 & 25 & 56 \\
\hline 157 & Landfill of waste: Textiles & 56 & 74 & 57 & 46 & 36 & 72 \\
\hline 158 & Landfill of waste: Wood & 62 & 76 & 68 & 40 & 36 & 68 \\
\hline 159 & Activities of membership organisation n.e.c. & 23 & 9 & 28 & 16 & 27 & 9 \\
\hline 160 & Recreational, cultural and sporting activities & 25 & 11 & 44 & 10 & 54 & 22 \\
\hline 161 & Other service activities & 1 & 13 & 18 & 21 & 8 & 5 \\
\hline 162 & Private households with employed persons & 93 & 38 & 39 & 50 & 141 & 119 \\
\hline 163 & Extra-territorial organizations and bodies & 138 & 146 & 153 & 144 & 141 & 153 \\
\hline
\end{tabular}

\section{References}

1. Savaresi, A. The Paris agreement: A new beginning? J. Energy Nat. Resour. Law 2016, 34, 16-26. [CrossRef]

2. Leontief, W.W. Input-Output Economics; Oxford University Press: Oxford, UK, 1986.

3. He, J. Quesnay's tableau économique. Population 1972, 27, 914-915. [CrossRef]

4. Walras, L. Elements of Pure Economics; Routledge: London, UK, 2013. 
5. Eurostat/European Commission. Eurostat Manual of Supply, Use and Input-Output Tables, 2008th ed.; Office for Official Publications of the European Communities: Luxembourg, 2008. Available online: https:/ / ec.europa.eu/eurostat/documents/3859598/590211 3/KS-RA-07-013-EN.PDF/b0b3d71e-3930-4442-94be-70b36cea9b39 (accessed on 22 August 2021).

6. Leontief, W.W. The Structure of American Economy, 1919-1929: An Empirical Application of Equilibrium Analysis; Harvard University Press: Cambridge, MA, USA, 1941.

7. Leontief, W. Output, employment, consumption, and investment. Q. J. Econ. 1944, 58, 290-314. [CrossRef]

8. Dorfman, R. Wassily leontief's contribution to economics. Swed. J. Econ. 1973, 75, 430-449. [CrossRef]

9. Fletcher, J.E. Input-output analysis and tourism impact studies. Ann. Tour. Res. 1989, 16, 514-529. [CrossRef]

10. Moses, L.N. The stability of interregional trading patterns and input-output analysis. Am. Econ. Rev. 1955, 45, 803-826.

11. Miyazawa, K. Input-Output Analysis and the Structure of Income Distribution; Springer: Berlin, Germany, 2012.

12. Rasmussen, P.N. Studies in Inter-Sectoral Relations. E. Harck. Energy Power Eng. 2017, 9, 1.

13. Hirschman, A.O. The Strategy of Economic Development; Yale University Press: New Haven, CT, USA, 1958.

14. Akamatsu, K. A theory of unbalanced growth in the world economy. Weltwirtschaftliches Arch. 1961, 86, $196-217$.

15. Hirschman, A.O.; Lindblom, C.E. Economic development, research and development, policy making: Some converging views Syst. Res. 1962, 7, 211-222. [CrossRef]

16. Hansen, N.M. Unbalanced growth and regional development. Econ. Inq. 1965, 4, 3-14. [CrossRef]

17. Miyazawa, K. Foreign trade multiplier, input-output analysis and the consumption function. Q. J. Econ. 1960, 74, 53-64. [CrossRef]

18. Miyazawa, K. Internal and external matrix multipliers in the input-output model. Hitotsubashi J. Econ. 1966, 7, 38-55.

19. Miyazawa, K. Input-output analysis and interrelational income multiplier as a matrix. Hitotsubashi J. Econ. 1968, 8, 39-58.

20. Miyazawa, K. An analysis of the interdependence between service and goods-producing sectors. Hitotsubashi J. Econ. 1971, 12, 10-21.

21. Sonis, M.; Hewings, G.J. Error and sensitivity input-output analysis: A new approach. In Frontiers of Input-Output Analysis; Miller, R.E., Polenske, K.R., Rose, A.Z., Eds.; Oxford University Press, 1989; pp. 232-244. Available online: http:/ / real.illinois. edu/d-paper/09/09-T-4.pdf (accessed on 22 August 2021).

22. Hewings, G.J.; Fonseca, M.; Guilhoto, J.; Sonis, M. Key sectors and structural change in the Brazilian economy: A comparison of alternative approaches and their policy implications. J. Policy Model. 1989, 11, 67-90. [CrossRef]

23. Sonis, M.; Hewings, G.J. Coefficient change in input-output models: Theory and applications. Econ. Syst. Res. 1992, 4, 143-158. [CrossRef]

24. Sonis, M.; Guilhoto, J.J.; Hewings, G.J.; Martins, E.B. Linkages, key sectors, and structural change: Some new perspectives. Dev. Econ. 1995, 33, 243-246. [CrossRef]

25. Israilevich, P.R.; Hewings, G.J.; Sonis, M.; Schindler, G.R. Forecasting structural change with a regional econometric input-output model. J. Reg. Sci. 1997, 37, 565-590. [CrossRef]

26. Hewings, G.J.; Sonis, M.; Guo, J.; Israilevich, P.R.; Schindler, G.R. The hollowing-out process in the Chicago economy, 1975-2011. Geogr. Anal. 1998, 30, 217-233. [CrossRef]

27. Sonis, M.; Hewings, J.D.; Guo, J. A new image of classical key sector analysis: Minimum information decomposition of the Leontief inverse. Econ. Syst. Res. 2000, 12, 401-423. [CrossRef]

28. Okuyama, Y.; Hewings, G.J.; Sonis, M. Measuring economic impacts of disasters: Interregional input-output analysis using sequential interindustry model. In Modeling Spatial and Economic Impacts of Disasters; Springer: Berlin, Germany, 2004; pp. 77-101.

29. Guilhoto, J.; Sonis, M.; Hewings, G.J. Linkages and multipliers in a multiregional framework: Integration of alternative approaches. Australas. J. Reg. Stud. 2005, 11, 75-89. [CrossRef]

30. Geschke, A.; Hadjikakou, M. Virtual laboratories and MRIO analysis-An introduction. Econ. Syst. Res. 2017, $29,143-157$. [CrossRef]

31. Rahman, M.D.A.; Los, B.; Geschke, A.; Xiao, Y.; Kanemoto, K.; Lenzen, M. A flexible adaptation of the WIOD database in a virtual laboratory. Econ. Syst. Res. 2017, 29, 187-208. [CrossRef]

32. Wiedmann, T. An input-output virtual laboratory in practice-survey of uptake, usage and applications of the first operational IELab. Econ. Syst. Res. 2017, 29, 1-17. [CrossRef]

33. Avelino, A.F.T. Disaggregating input—output tables in time: The temporal input-Output framework. Econ. Syst. Res. 2017, 29, 313-334. [CrossRef]

34. Ye, Y.; Qi, Q.; Jiang, L.; Li, X. Spatial-temporal changes in grain input-output and the driving mechanism in China since 1985. Int. J. Agric. Sustain. 2017, 1-12. [CrossRef]

35. Thekdi, S.A.; Santos, J.R. Supply Chain Vulnerability Analysis Using Scenario-Based Input-Output Modeling: Application to Port Operations. Risk Anal. 2016, 36, 1025-1039. [CrossRef]

36. Baldwin, R.; Lopez-Gonzalez, J. Supply-chain trade: A portrait of global patterns and several testable hypotheses. World Econ. 2015, 38, 1682-1721. [CrossRef]

37. Kitzes, J. An introduction to environmentally-extended input-output analysis. Resources 2013, 2, 489-503. [CrossRef]

38. Daly, H.A. On economics as a life science. J. Politi. Econ. 1968, 76, 392. [CrossRef]

39. Ayres, R.U.; Kneese, A.V. Production, consumption, and externalities. Am. Econ. Rev. 1969, 59, $282-297$.

40. Victor, P.A. Input-Output Analysis and the Study of Economic and Environmental Interactions. Ph.D. Thesis, University of British Columbia, Vancouver, BC, Canada, 1971. 
41. Lenzen, M. Environmentally important paths, linkages and key sectors in the Australian economy. Struct. Chang. Econ. Dyn. 2003, 14, 1-34. [CrossRef]

42. A Key Sector Approach to the Environmentally Extended Input-Output Analysis of the UK Economy. Available online: https:/ /link.springer.com/chapter/10.1057/9780230362437_5 (accessed on 22 August 2021).

43. Shmelev, S.E. (Ed.) Sustainable Cities Reimagined: Multidimensional Assessment and Smart Solutions; Routledge: London, UK, 2019.

44. Leontief, W. Environmental repercussions and the economic structure: An Input-output approach. Rev. Econ. Stat. 1970, 52, 262-271. [CrossRef]

45. Leontief, W.W.; Ford, D. Air Pollution and the Economic Structure: Empirical Results of Input-Output Computations; Harvard University: Cambridge, MA, USA, 1971.

46. Leontief, W. Sructure of the world economy: Outline of a simple input-output formulation. Am. Econ. Rev. 1974, 64, 823-834.

47. Carter, A.P. Energy, environment, and economic growth. Bell J. Econ. Manag. Sci. 1974, 5, 578-592. [CrossRef]

48. Carter, A.P. Energy and the Environment. A Structural Analysis; Brandeis University Press: Waltham, MA, USA, 1976.

49. Herendeen, R.; Tanaka, J. Energy cost of living. Energy 1976, 1, 165-178. [CrossRef]

50. Proops, J.L.R. Input-output analysis and energy intensities: A comparison of some methodologies. Appl. Math. Model. 1977, 1, 181-186. [CrossRef]

51. Park, S.-H. An input-output framework for analysing energy consumption. Energy Econ. 1982, 4, 105-110. [CrossRef]

52. Proops. Modelling the energy-output ratio. Energy Econ. 1984, 6, 47-51. [CrossRef]

53. Gay, P.W.; Proops, J.L.R. Carbon dioxide production by the UK economy: An input-output assessment. Appl. Energy 1993, 44, 113-130. [CrossRef]

54. Polenske, K.R.; Lin, X. Conserving energy to reduce carbon dioxide emissions in China. Struct. Chang. Econ. Dyn. 1993, 4, 249-265. [CrossRef]

55. Minx, J.C.; Wiedmann, T.; Wood, R.; Peters, G.; Lenzen, M.; Owen, A.; Scott, K.; Barrett, J.; Hubacek, K.; Baiocchi, G.; et al. Input-output analysis and carbon footprinting: An overview of applications. Econ. Syst. Res. 2009, 21, 187-216. [CrossRef]

56. Peters, G.P.; Minx, J.C.; Weber, C.L.; Edenhofer, O. Growth in emission transfers via international trade from 1990 to 2008. Proc. Natl. Acad. Sci. USA 2011, 108, 8903-8908. [CrossRef]

57. Anderson, A.W.; Manning, T.W. The use of input-output analysis in evaluating water resource development. Can. J. Agric. Econ. 1983, 31, 15-26. [CrossRef]

58. Lenzen, M.; Foran, B. An input-output analysis of Australian water usage. Water Policy 2001, 3, 321-340. [CrossRef]

59. Dietzenbacher, E.; Velázquez, E. Analysing andalusian virtual water trade in an input-output framework. Reg. Stud. 2007, 41, 185-196. [CrossRef]

60. Lenzen, M. Understanding virtual water flows: A multiregion input-output case study of Victoria. Water Resour. Res. 2009, 45, 9. [CrossRef]

61. Leontief, W. Natural resources, environmental disruption, and the future world economy. J. Int. Aff. 1977, $31,267$.

62. Duchin, F. The conversion of biological materials and wastes to useful products. Struct. Chang. Econ. Dyn. 1990, 1, 243-261. [CrossRef]

63. Duchin, F. Household Use and Disposal of Plastics an Input Output Case Study for New York City; New York University: New York, NY, USA, 1994.

64. Ferrer, G.; Ayres, R.U. The impact of remanufacturing in the economy. Ecol. Econ. 2000, 32, 413-429. [CrossRef]

65. Nakamura, S. An interindustry approach to analyzing economic and environmental effects of the recycling of waste. Ecol. Econ. 1999, 28, 133-145. [CrossRef]

66. Nakamura, S.; Kondo, Y. Recycling, landfill consumption, and $\mathrm{CO}_{2}$ emission: Analysis by waste input-output model. J. Mater Cycles Waste Manag. 2002, 4, 2-11.

67. Hoekstra, R.; van den Bergh, J.C.J.M. Structural decomposition analysis of physical flows in the economy. Environ. Resour. Econ. 2002, 23, 357-378. [CrossRef]

68. Suh, S. Theory of materials and energy flow analysis in ecology and economics. Ecol. Model. 2005, 189, 251-269. [CrossRef]

69. Kondo, Y.; Nakamura, S. Waste input-output linear programming model with its application to eco-efficiency analysis. Econ. Syst. Res. 2005, 17, 393-408. [CrossRef]

70. Dietzenbacher, E. Waste treatment in physical input-output analysis. Ecol. Econ. 2005, 55, 11-23. [CrossRef]

71. Nakamura, S.; Kondo, Y. A waste input-output life-cycle cost analysis of the recycling of end-of-life electrical home appliances. Ecol. Econ. 2006, 57, 494-506. [CrossRef]

72. Barker, T. Projecting economic structure with a large-scale econometric model. Futures 1981, 13, 458-467. [CrossRef]

73. Kananen, I.; Korhonen, P.; Wallenius, J.; Wallenius, H. Multiple objective analysis of input-output models for emergency management. Oper. Res. 1990, 38, 193-201. [CrossRef]

74. Luptáčik, M.; Böhm, B. An environmental input-output model with multiple criteria. Ann. Oper. Res. 1994, 54, 119-127. [CrossRef]

75. Nagashima, F.; Kagawa, S.; Suh, S.; Nansai, K.; Moran, D. Identifying critical supply chain paths and key sectors for mitigating primary carbonaceous PM2.5 mortality in Asia. Econ. Syst. Res. 2017, 29, 105-123. [CrossRef]

76. Acquaye, A.; Feng, K.; Oppon, E.; Salhi, S.; Ibn-Mohammed, T.; Genovese, A.; Hubacek, K. Measuring the environmental sustainability performance of global supply chains: A multi-regional input-output analysis for carbon, sulphur oxide and water footprints. J. Environ. Manag. 2017, 187, 571-585. [CrossRef] [PubMed] 
77. Reutter, B.; Lant, P.; Reynolds, C.; Lane, J. Food waste consequences: Environmentally extended input-output as a framework for analysis. J. Clean. Prod. 2017, 153, 506-514. [CrossRef]

78. Ehrenfeld, J.; Gertler, N. Industrial ecology in practice: The evolution of interdependence at Kalundborg. J. Ind. Ecol. 1997, 1, 67-79. [CrossRef]

79. Erkman, S. Industrial ecology: An historical view. J. Clean. Prod. 1997, 5, 1-10. [CrossRef]

80. Frosch, R.A. Industrial ecology: A philosophical introduction. Proc. Natl. Acad. Sci. USA 1992, 89, 800-803. [CrossRef] [PubMed]

81. Graedel, T.E.; Allenby, B.R. Industrial Ecology and Sustainable Engineering: International Edition; Pearson Education Inc.: Hoboken, NJ, USA, 2010.

82. Jelinski, L.W.; Graedel, T.E.; Laudise, R.A.; McCall, D.W.; Patel, C.K. Industrial ecology: Concepts and approaches. Proc. Natl. Acad. Sci. USA 1992, 89, 793-797. [CrossRef]

83. Thomas, V.M. Industrial ecology: Towards closing the materials cycle. J. Ind. Ecol. 1997, 1, 149-151. [CrossRef]

84. Fischer-Kowalski, M.; Krausmann, F.; Giljum, S.; Lutter, S.; Mayer, A.; Bringezu, S.; Moriguchi, Y.; Schütz, H.; Schandl, H.; Weisz, H. Methodology and indicators of economy-wide material flow accounting. J. Ind. Ecol. 2011, 15, 855-876. [CrossRef]

85. Haberl, H.; Fischer-Kowalski, M.; Krausmann, F.; Weisz, H.; Winiwarter, V. Progress towards sustainability? What the conceptual framework of material and energy flow accounting (MEFA) can offer. Land Use Policy 2004, 21, 199-213. [CrossRef]

86. Hinterberger, F.; Giljum, S.; Hammer, M. Material Flow Accounting and Analysis (MFA); Sustainable Europe Research Institute (SERI Background Paper 2): Wien, Austria, 2013.

87. Moriguchi, Y. Recycling and waste management from the viewpoint of material flow accounting. J. Mater. Cycles Waste Manag. 1999, 1, 2-9.

88. Cabeza, L.F.; Rincón, L.; Vilariño, V.; Pérez, G.; Castell, A. Life cycle assessment (LCA) and life cycle energy analysis (LCEA) of buildings and the building sector: A review. Renew. Sustain. Energy Rev. 2014, 29, 394-416. [CrossRef]

89. Hellweg, S.; I Canals, L.M. Emerging approaches, challenges and opportunities in life cycle assessment. Science 2014, 344, 1109-1113. [CrossRef]

90. Curran, M.A. Environmental life-cycle assessment. Int. J. Life Cycle Assess. 1996, 1, 179. [CrossRef]

91. Guinée, J. Handbook on life cycle assessment-Operational guide to the ISO standards. Int. J. Life Cycle Assess. 2001, 6, 255. [CrossRef]

92. Gandy, M. Rethinking urban metabolism: Water, space and the modern city. City 2004, 8, 363-379. [CrossRef]

93. Kennedy, C.; Pincetl, S.; Bunje, P. The study of urban metabolism and its applications to urban planning and design. Environ. Pollut. 2011, 159, 1965-1973. [CrossRef]

94. Niza, S.; Rosado, L.; Ferrao, P. Urban metabolism. J. Ind. Ecol. 2009, 13, 384-405. [CrossRef]

95. Sahely, H.R.; Dudding, S.; Kennedy, C.A. Estimating the urban metabolism of Canadian cities: Greater Toronto Area case study. Can. J. Civ. Eng. 2003, 30, 468-483. [CrossRef]

96. Lenzen, M.; Kanemoto, K.; Moran, D.; Geschke, A. Mapping the Structure of the World Economy. Environ. Sci. Technol. 2012, 46, 8374-8381. [CrossRef]

97. Schanes, K.; Giljum, S.; Hertwich, E. Low carbon lifestyles: A framework to structure consumption strategies and options to reduce carbon footprints. J. Clean. Prod. 2016, 139, 1033-1043. [CrossRef]

98. Moran, D.; Wood, R.; Hertwich, E.; Mattson, K.; Rodriguez, J.F.D.; Schanes, K.; Barrett, J. Quantifying the potential for consumeroriented policy to reduce European and foreign carbon emissions. Clim. Policy 2018, 20, S28-S38. [CrossRef]

99. Ivanova, D.; Barrett, J.; Wiedenhofer, D.; Macura, B.; Callaghan, M.; Creutzig, F. Quantifying the potential for climate change mitigation of consumption options. Environ. Res. Lett. 2020, 15, 093001. [CrossRef]

100. Roy, B.; Vanderpooten, D. The European school of MCDA: Emergence, basic features and current works. J. Multi-Crit. Decis. Anal. 1996, 5, 22-38. [CrossRef]

101. Roy, B. ELECTRE III: Un algorithme de classement fondé sur une représentation floue des préférences en présence de critères multiples. Cah. Du CERO 1978, 20, 3-24.

102. Roy, B. The outranking approach and the foundations of ELECTRE methods. In Readings in Multiple Criteria Decision Aid; Springer: Berlin, Germany, 1990; pp. 155-183.

103. Handfield, R.; Walton, S.V.; Sroufe, R.; Melnyk, S.A. Applying environmental criteria to supplier assessment: A study in the application of the analytical hierarchy process. Eur. J. Oper. Res. 2002, 141, 70-87. [CrossRef]

104. Saaty, T.L. Decision making with the analytic hierarchy process. Int. J. Serv. Sci. 2008, 1, 83-98. [CrossRef]

105. Zahedi, F. The analytic hierarchy process-A survey of the method and its applications. Interfaces 1986, 16, 96-108. [CrossRef]

106. Ignizio, J.P. Goal Programming and Extensions; Lexington Books: Washington, DC, USA, 1976.

107. Lee, S.M. Goal Programming for Decision Analysis; Auerbach Publications: Boca Raton, FL, USA, 1972.

108. Marler, R.T.; Arora, J.S. The weighted sum method for multi-objective optimization: New insights. Struct. Multidiscip. Optim. 2010, 41, 853-862. [CrossRef]

109. Rowley, H.V.; Peters, G.M.; Lundie, S.; Moore, S.J. Aggregating sustainability indicators: Beyond the weighted sum. J. Environ. Manag. 2012, 111, 24-33. [CrossRef]

110. Munda, G. Multicriteria Evaluation in a Fuzzy Environment: Theory and Applications in Ecological Economics; Springer: Berlin, Germany, 1995.

111. Menegolo, L.; Pereira, A. NAIADE-Manual; Joint Research Centre of the European Commission: Ispra, Italy, 1996. 
112. Munda, G. A NAIADE based approach for sustainability benchmarking. Int. J. Environ. Technol. Manag. 2005, 6, 65-78. [CrossRef]

113. Nutt, D.J.; King, L.A.; Phillips, L.D. Drug harms in the UK: A multicriteria decision analysis. Lancet 2010, 376, 1558-1565. [CrossRef]

114. Baltussen, R.; Youngkong, S.; Paolucci, F.; Niessen, L. Multi-criteria decision analysis to prioritize health interventions: Capitalizing on first experiences. Health Policy 2010, 96, 262-264. [CrossRef] [PubMed]

115. Diaby, V.; Campbell, K.; Goeree, R. Multi-criteria decision analysis (MCDA) in health care: A bibliometric analysis. Oper. Res. Health Care 2013, 2, 20-24. [CrossRef]

116. Datta, A.; Ray, A.; Bhattacharya, G.; Saha, H. Green energy sources (GES) selection based on multi-criteria decision analysis (MCDA). Int. J. Energy Sect. Manag. 2011, 5, 271-286. [CrossRef]

117. Shmelev, S.E.; van den Bergh, J.C.J.M. Optimal diversity of renewable energy alternatives under multiple criteria: An application to the UK. Renew. Sustain. Energy Rev. 2016, 60, 679-691. [CrossRef]

118. Terrados, J.; Almonacid, G.; PeRez-Higueras, P. Proposal for a combined methodology for renewable energy planning. Application to a Spanish region. Renew. Sustain. Energy Rev. 2009, 13, 2022-2030. [CrossRef]

119. Wang, J.-J.; Jing, Y.-Y.; Zhang, C.-F.; Zhao, J.-H. Review on multi-criteria decision analysis aid in sustainable energy decisionmaking. Renew. Sustain. Energy Rev. 2009, 13, 2263-2278. [CrossRef]

120. Omann, I. Multi-Criteria Decision Aid as an Approach for Sustainable Development Analysis and Implementation. Available online: https: / / www.semanticscholar.org/paper/MULTI-CRITERIA-DECISION-AID-AS-AN-APPROACH-Omann/12a0a2 066bcc7a70fdd9be433521da3c3ed27e7e\#paper-header (accessed on 22 August 2021).

121. De Luca, A.I.; Iofrida, N.; Leskinen, P.; Stillitano, T.; Falcone, G.; Strano, A.; Gulisano, G. Life cycle tools combined with multi-criteria and participatory methods for agricultural sustainability: Insights from a systematic and critical review. Sci. Total Environ. 2017, 595, 352-370. [CrossRef]

122. Fernandes, I.D.; Ferreira, F.A.; Bento, P.; Jalali, M.S.; António, N.J. Assessing sustainable development in urban areas using cognitive mapping and MCDA. Int. J. Sustain. Dev. World Ecol. 2017, 25, 216-226. [CrossRef]

123. Shmelev, S.E. (Ed.) Green Economy Reader: Lectures in Ecological Economics and Sustainability; Springer: Berlin, Germany, 2017; 463p.

124. Shmelev, S.E.; Rodríguez-Labajos, B. Dynamic multidimensional assessment of sustainability at the macro level: The case of Austria. Ecol. Econ. 2009, 68, 2560-2573. [CrossRef]

125. Shmelev, S.E. Dynamic sustainability assessment: The case of Russia in the period of transition (1985-2008). Ecol. Econ. 2011, 70, 2039-2049. [CrossRef]

126. Figueira, J.; Mousseau, V.; Roy, B. ELECTRE methods. In Multiple Criteria Decision Analysis: State of the Art Surveys; Springer: New York, NY, USA, 2005; pp. 133-153.

127. Cinelli, M.; Coles, S.R.; Kirwan, K. Analysis of the potentials of multi criteria decision analysis methods to conduct sustainability assessment. Ecol. Indic. 2014, 46, 138-148. [CrossRef]

128. Boggia, A.; Cortina, C. Measuring sustainable development using a multi-criteria model: A case study. J. Environ. Manag. 2010, 91, 2301-2306. [CrossRef] [PubMed]

129. Myllyviita, T.; Leskinen, P.; Lähtinen, K.; Pasanen, K.; Sironen, S.; Kähkönen, T.; Sikanen, L. Sustainability assessment of wood-based bioenergy-A methodological framework anda case-study. Biomass Bioenergy 2013, 59, 293-299. [CrossRef]

130. Office for National Statistics. Sustainable Development Indicators; Office for National Statistics: Newport, UK, 2015.

131. World Bank. DataBank I The World Bank. 2017. Available online: http://databank.worldbank.org/data/home.aspx (accessed on 22 August 2021).

132. World Nuclear Association. Nuclear Shares of Electricity. 2017. Available online: http:/ /www.world-nuclear.org/informationlibrary / facts-and-figures/nucleargeneration-by-country.aspx (accessed on 22 August 2021).

133. BP Statistical Review of World Energy; BP Statistical Review: London, UK. 2016. Available online: http:/ /large.stanford.edu/ courses/2016/ph240/stanchi2/docs/bp-2016.pdf (accessed on 22 August 2021).

134. Government of Germany. Climate Action Plan 2050. Available online: https://www.bmu.de/en/topics/climate-adaptation/ climate-protection/national-climate-policy/climate-action-plan-2050-germanys-long-term-low-greenhouse-gas-emissiondevelopment-strategy (accessed on 22 August 2021).

135. OECD. Input-Output Tables [WWW Document]. 2015. Available online: http:/ / stats.oecd.org/Index.aspx?DataSetCode=IOTS (accessed on 22 August 2021).

136. OECD. OECD Environmental Performance Reviews: Sweden 2014; OECD Publishing: Paris, France, 2014. [CrossRef]

137. OECD Environmental Performance Reviews: Austria 2013; OECD Publshing: Paris, France, 2013.

138. Lenzen, M.; Moran, D.; Kanemoto, K.; Geschke, A. Building eora: A global multi-region input-output database at high country and sector resolution. Econ. Syst. Res. 2013, 25, 20-49. [CrossRef]

139. Aguiar, A.; Narayanan, B.; McDougall, R. An overview of the GTAP 9 data base. J. Glob. Econ. Anal. 2006, 1, 181-208. [CrossRef]

140. Timmer, M.; Erumban, A.A.; Gouma, R.; Los, B.; Temurshoev, U.; de Vries, G.J.; Arto, I.; Genty, V.A.A.; Neuwahl, F.; Rueda-Cantuche, J.M.; et al. The World Input-Output Database (WIOD): Contents, Sources and Methods (No. 20120401), IIDE Discussion Papers; Institue for International and Development Economics, 2012. Available online: https://econpapers.repec.org/ paper/lnzwpaper/20120401.htm (accessed on 22 August 2021). 
141. Tukker, A.; Koning, A.; de Wood, R.; Hawkins, T.; Lutter, S.; Acosta, J.; Cantuche, J.M.R.; Bouwmeester, M.; Oosterhaven, J.; Drosdowski, T.; et al. Exiopol-development and illustrative analyses of a detailed global Mr Ee Sut/Iot. Econ. Syst. Res. 2013, 25, 50-70. [CrossRef]

142. Rogers, M.; Bruen, M. Choosing realistic values of indifference, preference and veto thresholds for use with environmental criteria within ELECTRE. Eur. J. Oper. Res. 1998, 107, 542-551. [CrossRef]

143. Blöchl, F.; Theis, F.J.; Vega-Redondo, F.; Fisher, E.O. Vertex centralities in input-output networks reveal the structure of modern economies. Phys. Rev. E 2011, 83, 46127. [CrossRef]

144. U.S. Department of Energy. Comprehensive Annual Energy Data and Sustainability Performance. 2017. Available online: https:/ / ctsedwweb.ee.doe.gov/Annual/Report/Report.aspx (accessed on 22 August 2021).

145. El-Erian, M.A.; Spence, M. Growth strategies and dynamics: Insights from country experiences. World Econ. J. $2008,9,1$.

146. OECD Environmental Performance Reviews: Austria 2013 OECD Read Edition. OECD iLibrary. Available online: http:/ / www.keepeek.com/Digital-Asset-Management/oecd/environment/oecd-environmental-performance-reviewsaustria-2013_9789264202924-en (accessed on 22 August 2021).

147. Agence France-Presse. All Electricity in Austria's Largest State Now Produced from Renewables. Available online: https://www. theguardian.com/world/2015/nov/06/all-electricity-in-austrias-largest-state-now-produced-from-renewables (accessed on 22 August 2021).

148. Chan, C.K.; Yao, X. Air pollution in mega cities in China. Atmos. Environ. 2008, 42, 1-42. Available online: https://www. sciencedirect.com/science/article/abs/pii/S1352231007007911 (accessed on 22 August 2021). [CrossRef]

149. Feng, T. Controlling air pollution in China. Edw. Elgar Publ. 1999. Available online: https://www.e-elgar.com/shop/gbp/ controlling-air-pollution-in-china-9781840641004.html (accessed on 30 June 2017).

150. Xiao, Y.; Wang, X.; Wang, X.; Wu, Z.; Liu, W. The Coordinated Development Path of Renewable Energy and National Economy in China Considering Risks of Electricity Market and Energy Policy. IEEE Trans. Ind. Inform. 2017. [CrossRef]

151. Zhao, X.; Luo, D. Driving force of rising renewable energy in China: Environment, regulation and employment. Renew. Sustain. Energy Rev. 2017, 68, 48-56. [CrossRef]

152. Reuters. China to Invest $£ 292 \mathrm{bn}$ in Renewable Power by 2020. Available online: https://www.theguardian.com/business/2017 /jan/05/china-invest-renewable-fuel-2020-energy (accessed on 22 August 2021).

153. OECD. OECD Environmental Performance Reviews: France 2016; OECD Publishing: Paris, France, 2016. [CrossRef]

154. Lindegren, M.; Möllmann, C.; Nielsen, A.; Stenseth, N.C. Preventing the collapse of the Baltic cod stock through an ecosystembased management approach. Proc. Natl. Acad. Sci. USA 2009, 106, 14722-14727. [CrossRef] [PubMed]

155. Neslen, A. Donald Trump "Taking Steps to Abolish Environmental Protection Agency". Guardian. 2017. Available online: https: / / www.theguardian.com/us-news/2017/feb/02/donald-trump-plans-to-abolish-environmental-protection-agency (accessed on 22 August 2021).

156. State of California Energy Commission. California 2030 Climate Commitment; 2015.

157. Oregon Department of Energy. Renewable Portfolio Standard. 2016. Available online: http://www.oregon.gov/energy/energyoregon/Pages/Renewable-Portfolio-Standard.aspx (accessed on 22 August 2021). 